\title{
Welfare Production in Canada and Tanzania: The Ismaili Imamat, Ismaili Community Institutions and the Aga Khan Development Network (AKDN)
}

\section{Farzana Nanji Jiwani}

\author{
A thesis submitted to \\ the Faculty of Graduate and Postdoctoral Affairs \\ in partial fulfillment of the requirements for the degree of \\ Doctor of Philosophy \\ in
}

Public Policy and Administration

Carleton University

Ottawa, Ontario

(C) 2013 Farzana Nanji Jiwani 


\begin{abstract}
This dissertation examines the evolution in thinking about public policy devoted to social protection by drawing on welfare theory and its extensions, state-civil society frameworks, and transnational networks. It does this through case studies of the Ismaili Imamat, Ismaili community institutions, and AKDN in Canada and Tanzania. The key question posed is: How are we to understand the role in welfare provision of an evolving trans-state - or perhaps international non-state - cluster of institutions that have their origins and owe their existence to a religious faith? The importance of understanding hybridity, intermediary roles, scale, and regional configurations are highlighted.

The dissertation comes to the following conclusions on the AKDN and welfare provision. First, regarding the AKDN, although the Imamat level may be occupying that intermediary space and is involved in the orchestration and management of welfare production, the capacity for the mechanisms of the Imamat to also engage in a fully realized potential of a logic of hybridity is a more difficult proposition. The AKDN is a culmination of elements that began in the Ismaili community, and it is still evolving. So the capacity to seamlessly engage in a logic of hybridity or not be confined to a particular sector or scale is an ongoing process. Second, regarding welfare provision, the focus on self-reliance and independence are important factors in meeting welfare needs. However, context is important. For example, in Canada, the Ismaili community institutions are more robust, highly professional, and are operating within the broader context of Canadian state welfare provision and other external services. This in not the case in
\end{abstract} Tanzania where community institutions are resource strapped and government or external 
services are unavailable. As well, the extent of collaboration between the more comprehensive AKDN entities and community institutions in Tanzania are unresolved. Although there were pockets of collaboration between AKDN entities and government, it could be described as strategic cooperation rather than co-production. Finally, the level of Imamat engagement in welfare production demonstrated that innovation in this area is rooted in the need to break away from sector confinements and re-evaluate thinking about how and where welfare production can take place. 


\begin{abstract}
AKNOWLEDGEMENTS
I would like to thank my supervisor, Dr. Leslie A. Pal, who recognized the potential of a percolating research idea and provided the support and space for me to develop my research proposal. During the research phase and in reading the many dissertation drafts, he expertly balanced his encouragement, constructive criticism, and challenges. There are maybe a few times in your professional or academic life that you are lucky to cross paths with an individual who is genuinely interested in your growth and success and who pushes you beyond your comfort zone to ensure that you learn the necessary lessons to propel your thinking to the next level. I was fortunate to be able to seek crucial guidance from Dr. Pal, who was instrumental in seeing me through to completion. I would also like to thank my two committee members, Professor Frances Abele and Professor Karim H. Karim, who were both so encouraging from the outset and who acted as invaluable sounding boards during the proposal phase. Their patience in reading early drafts and providing thoughtful insights and comments made the final dissertation much stronger.

I would like to thank my family for all their support and unwavering confidence that I would see that elusive finish line. I am grateful to my parents who instilled the importance of learning and finding my own path. There are always ups and downs in the writing process, but my nephew and niece in particular, who pulled me away to enter their world when I needed it most, ensured more ups than downs.

I would also like to thank all the research participants who were so generous with their time and provided thoughtful and reflective answers to questions I posed, without which this research endeavour would not have been possible.
\end{abstract}




\section{TABLE OF CONTENTS}

CHAPTER 1: INTRODUCTION AND THEORETICAL FRAMEWORK ............ 1

Dissertation Overview ............................................................................. 1

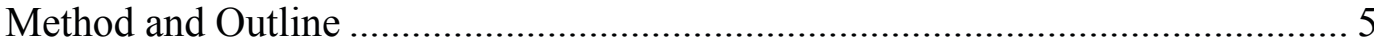

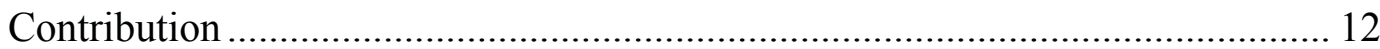

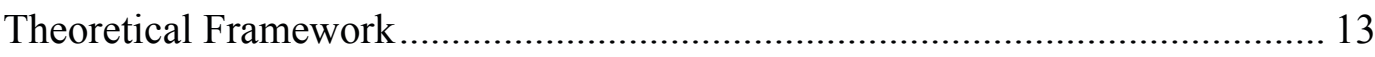

Theory Link to Case Studies............................................................................ 25

CHAPTER 2: ISMAILI HISTORY AND BACKGROUND ..................................... 33

History and Background Overview ................................................................ 33

The Link of the Imam and his Community......................................................... 37

Imam as the Pinnacle ................................................................... 37

Allegiance of Ismailis to the Imam ................................................... 39

Ismaili Imamat - The Office of the Imam ........................................................ 42

Scope of the Imamat Mandate ............................................................... 44

Engagement Strategies and Mechanisms to Fulfil Mandate................... 47

Ismaili Governance and Institution Building................................................. 48

Ismaili Constitution.......................................................................... 48

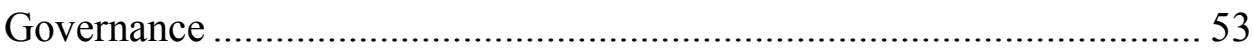

Self-reliance and Independence .................................................... 56

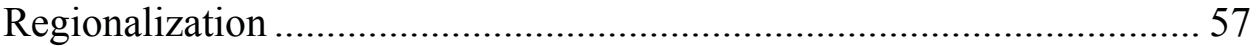

Centralization and Decentralization of Engagement Structures ........................ 58

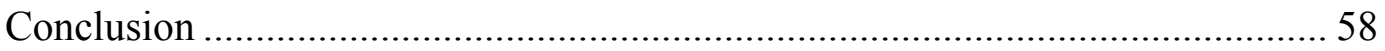

\section{CHAPTER 3: AGA KHAN DEVELOPMENT NETWORK (AKDN)}

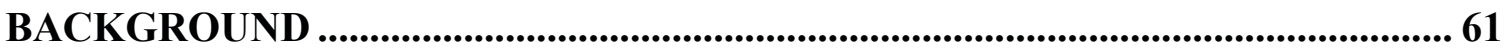

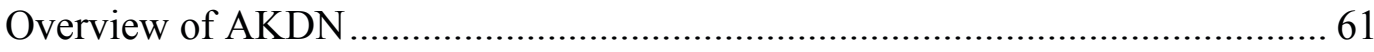

Aga Khan Fund for Economic Development (AKFED)....................... 65

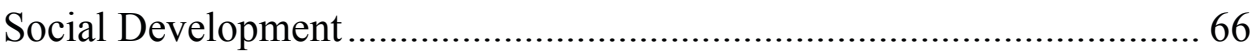

AKDN Affiliates and Other Organizations........................................ 70

AKDN funding for programs ......................................................... 71 
Community v. Broader Scale ......................................................................... 72

Authority of His Highness the Aga Khan .......................................................... 74

Din and Dunya - The Balance between Spiritual and Material............................. 77

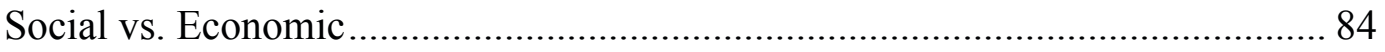

Logic of AKDN /HH/ AKDN Relationship to State ............................................. 88

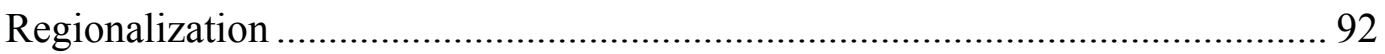

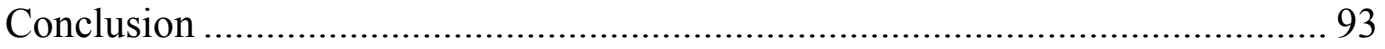

CHAPTER 4: CANADA CASE STUDY .......................................................................... 97

The Ismaili Community in Canada ........................................................................ 97

Changing Demographics................................................................... 100

Previous Studies of the Ismaili Community in Canada .......................... 102

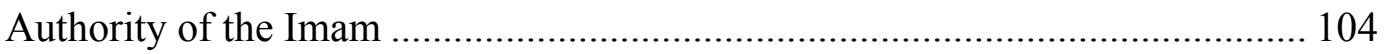

Structure of the Council and Other Bodies ...................................................... 106

Rationale for Programs and Services.................................................... 110

Funding for Jamati programs ............................................................ 118

Links with Councils regionally and internationally............................... 119

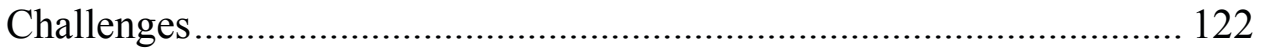

AKDN/AKFC and the Ismaili Community Link ................................................. 127

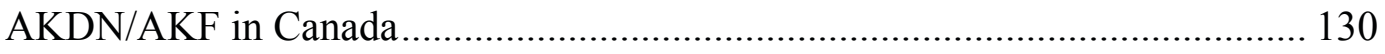

Structure ...................................................................................... 130

Role of the Imamat / AKDN as a Buffer/ Force-Field........................................ 134

Engagement of Government and NGO/Third Sector in Canada ........................ 136

Imamat /AKFC Link with Government and External organizations .................. 138

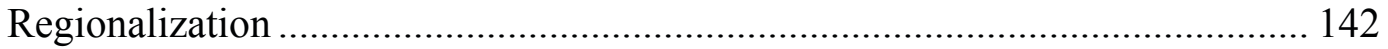

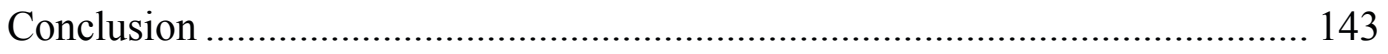

CHAPTER 5: TANZANIA CASE STUDY ................................................................ 146

The Ismaili Community in Tanzania .................................................................. 146

Changing Demographics................................................................... 149

Previous Studies of Ismailis in Tanzania ............................................ 150

Authority of the Imam/His Highness in the Ismaili community and AKDN ..... 152 
Structure of the Council and Other bodies......................................................... 155

Rationale for Ismaili Community services ............................................ 158

Funding and Redistribution Ismaili Council in Tanzania ....................... 159

Links with other Councils Regionally and Internationally ...................... 162

Ismaili Community Links with Government and External...................... 163

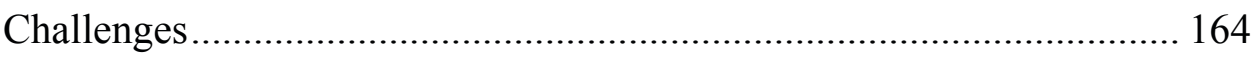

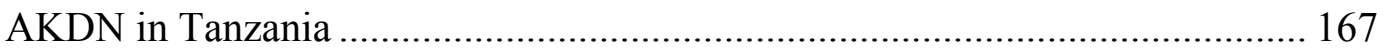

AKDN Overall Structure and Governance in Tanzania ......................... 167

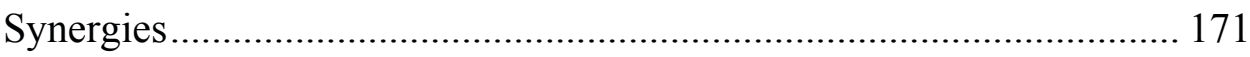

Rationale of AKDN Components ......................................................... 174

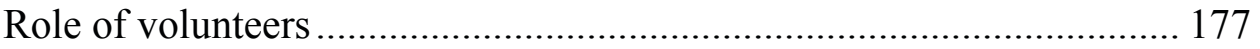

Social v. Economic Components of AKDN in Tanzania ....................... 179

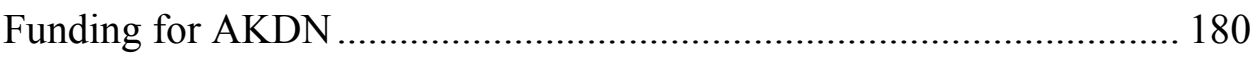

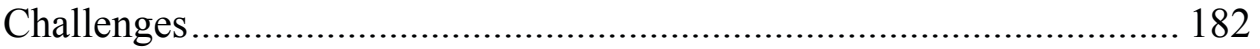

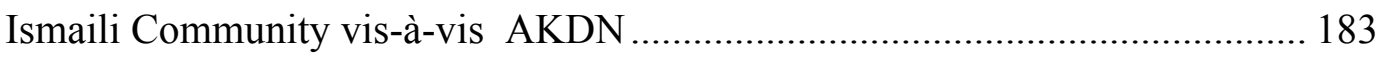

Role of HH/AKDN as a Buffer/ Force-Field .................................................... 191

Overview of landscape NGO/third sector and government in Tanzania ............. 193

Imamat/AKDN Link with Government and External Organizations ................. 195

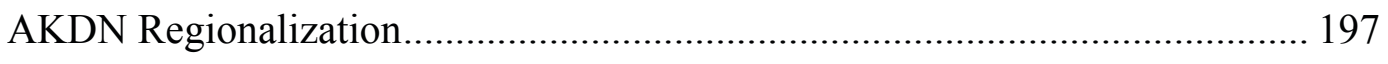

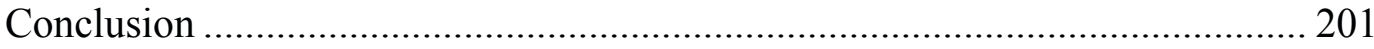

CHAPTER 6: CONCLUSION .................................................................................... 205

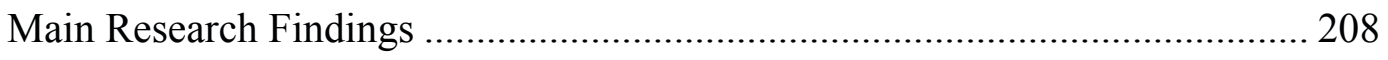

Overall Organization of AKDN and Ismaili Institutions .......................... 208

Comparison of Canadian and Tanzanian Key Themes............................ 213

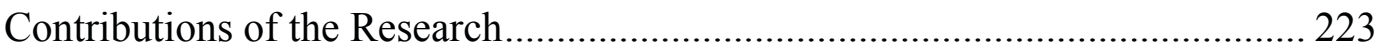

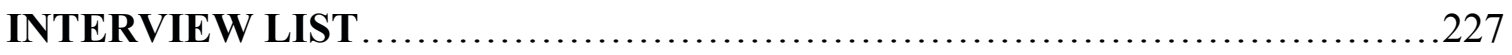

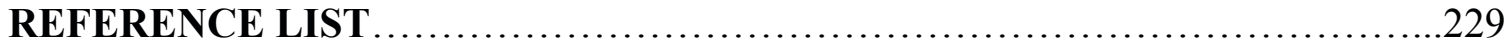

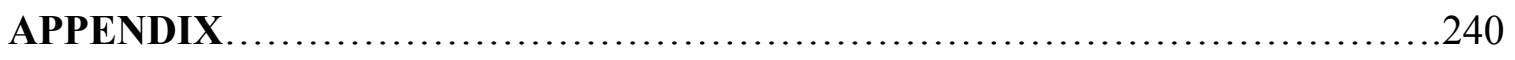




\section{LIST OF TABLES}

Table 3-1 Summary of Key AKDN and non-AKDN entities ....................63-64

Table 3-2 Key Coordination Mechanisms for the 'office of the Imam'..............76-77

Table 4-3 National Council and Boards in Canada ................................107-108

Table 4-4 Summary of Key AKDN and non-AKDN entities in Canada ..............133

Table 5-5 National Council and Boards in Tanzania ..............................156

Table 5-6 Key AKDN entities in Tanzania .................................170-171

Table 5-7 Ismaili Community Utilization of AKDN Programs and ..............186-188 Services in Tanzania

Table 6-8 Comparison of Key Themes - Canada and Tanzania .................215-221 


\section{ABBREVIATIONS}

AKAM Aga Khan Agency for Microfinance

AKDN Aga Khan Development Network

AKES Aga Khan Education Services

AKES,T Aga Khan Education Services, Tanzania

AKF Aga Khan Foundation

AKFC Aga Khan Foundation Canada

AKF,T Aga Khan Foundation Tanzania

AKF, EA Aga Khan Foundation, East Africa

AKFED Aga Khan Fund for Economic Development

AKHS Aga Khan Health Services

AKHS,T Aga Khan Health Services Tanzania

AKPBS Aga Khan Planning and Building Services

AKRSP Aga Khan Rural Support Program

AKTC Aga Khan Trust For Culture

AKU Aga Khan University

AKU-IED Aga Khan University Institute for Educational Development

AKU-IED-EA Aga Khan University Institute for Educational Development, East Africa

ANS Advanced Nursing Studies

CAB Conciliation and Arbitration Board

CIDA Canadian International Development Agency

CFC National Council for Canada 


\begin{tabular}{ll} 
DFID & Department for International Development (United Kingdom) \\
DII & Delegation of the Ismaili Imamat \\
DJI & Department of Jamati Institutions \\
EAU & East African Union \\
EPB & Economic Planning Board \\
FBO & Faith Based Organization \\
FOCUS & Focus Humanitarian Assistance \\
GCP & Global Centre for Pluralism \\
GRB & Grants and Review Board \\
HH & His Highness the Aga Khan \\
IIS & The Institute of Ismaili Studies \\
IMF & International Monetary Fund \\
IPS & Industrial Promotion Services \\
ISMC & The Institute for the Study of Muslim Civilisations \\
ITREB & Ismaili Tariqah and Religious Education Board \\
LIF & Leaders International Forum \\
NEB & National Education Board \\
NHB & National Health Board \\
OECD & Organization for Economic Cooperation and Development \\
PGME & Post Graduate Medical Education \\
TKW & Social Welfare Board \\
SWD & Social Welfare Department \\
\hline
\end{tabular}




$\begin{array}{ll}\text { TPS } & \text { Tourism Promotion Services } \\ \text { USAID } & \text { The United States Agency for International Development } \\ \text { UCA } & \text { University of Central Asia } \\ \text { WFDD } & \text { World Faiths Development Dialogue } \\ \text { YWCA } & \text { Young Women's Christian Association } \\ \text { YSB } & \text { Youth and Sports Board }\end{array}$




\section{CHAPTER 1: INTRODUCTION AND THEORETICAL FRAMEWORK}

\section{Dissertation Overview}

This dissertation focuses on the limitations of welfare state theory and seeks to broaden our definition of welfare, the rationale for welfare, and expand our understanding of the sites where welfare production can occur. The usual focus tends to be on the "statemarket nexus" as purveyors of welfare and on states within the OECD (Davis, 2001). In addition, there is an inclination to examine the various sources of welfare (i.e., state, market and to a lesser extent civil society/third sector, family, community) as silos (Evers, 2005) instead of a complex set of interconnections that may coexist. My research will draw on literature from welfare state theory, state civil society, scale, and transnational networks. The intersection of these bodies of literature will provide a nuanced theoretical lens to examine the sites and levels of welfare production. The main question that forms the basis of this dissertation is: How are we to understand the role in welfare provision of an evolving trans-state, or perhaps international non-state cluster of institutions that have their origins and owe their existence to a religious faith?

I began this dissertation with a focus on the role of community in welfare production, specifically the Ismaili community, a branch of the Shia Muslim tradition that comes together based on their allegiance to a living Imam. The community has in place communal welfare structures, and links to the broader initiatives of the Aga Khan 
Development Network (AKDN), a non-denominational development group of agencies. The role of the community in welfare production and issues of reciprocity and social obligation was at the forefront. However, it became clear that within the Ismaili community the Imam plays the dominant role in determining the strategic vision and directing resources. There is a high level of deference because of the spiritual link, so the authority of the Imam is not easily questioned. To some extent, donation driven welfare, and voluntary service linked to the Imam may supplant community reciprocity and obligation. Also, levels of engagement within the Ismaili community (Dossa, 1985) and differences in socio-economic status may affect the willingness to engage in community level welfare production.

Although the Ismaili context may seem like an example of "community" based welfare production, as my research progressed, it became clear that segmenting ideas of community, civil society, state, and market would lead to a limited understanding of welfare production. So I needed to explore a more complex set of interactions whereby the Ismaili Imamat, Ismaili community institutions and AKDN (in a developed and developing world context at local, national, regional, and international levels) are an example of a hybrid configuration. The theory section will unpack hybridity (Molina, 2009; Evers, 2005) in more detail. The various components in the Ismaili context exemplify characteristics of state (i.e., Ismaili Imamat - the office of the Imam, the Ismaili Constitution, AKDN interaction and agreements with government); market (economic component of AKDN - for profit/surplus generation - i.e., insurance, banks, tourism etc.); civil- society (social component - i.e., not for profit of AKDN); community (Ismaili Council structure and Institutions). This vivid example of the Ismaili Muslim 
community's internal structure of welfare production as well as the broader institutions of $\mathrm{AKDN}$ and its interaction with market, state, and civil society will provide a rich basis for understanding the complex interactions in which welfare production occurs.

The issue of how individuals meet their welfare needs and whether provisions are purchased, provided regardless of level of engagement in the market, targeted to a certain segment of the population, or a combination of approaches, is central when examining issues of welfare. How a society decides to address these issues has usually been the purview of the state with links to the market. Other segments like community, faith-based organizations and civil society have been examined, but to a lesser extent. The rationale for welfare and who has access to provisions needs consideration. For example, are individuals in a society eligible for welfare because they have a right, whereby all citizens are in some way guaranteed a certain level of welfare? Here, one could argue that an environment is created where there is a level of equality and individuals feel a sense of solidarity. This could possibly diminish resentment regarding who is receiving welfare and issues of dignity and feelings of stigma may be minimized. Another approach to welfare and who should receive it, is one where eligibility is based on means (i.e., meanstesting) (Esping-Anderson, 1990). This would entail specifying a criterion that would make an individual or family eligible for a particular welfare provision. This mechanism focuses on an obligation that government, or civil society organizations, have to care for a certain segment of the population that is unable to meet its welfare needs in a market driven environment. In this formulation, the state or other service provision may be tenuous because there is no right to welfare per se. Furthermore, it could create an environment where individuals who are achieving within the market context do not see 
the need or feel a responsibility to provide resources for individuals who cannot secure their own welfare needs.

The key areas of focus in this dissertation are the rationale for welfare, the sites of welfare production, and the accessibility of welfare provision. Also, the push and pull between aspects of self-reliance and independence with a more rights based approach to welfare is examined. In addition, by re-examining the assumption of state primacy, it allows for the consideration of transnational and regional approaches to welfare (Gough, 2004; Gough, 2001; Deacon, 2003). This dissertation highlights that the usual conception of welfare tends to be state-market centric (Davis, 2001), and although there have been extensions to include civil society and the community levels to varying degrees, the mode of analysis is still a segmented approach (Evers, 2005). Research questions are often framed as what does the state, market, civil society or community do regarding welfare? However, in doing so, one misses the potential for a logic of hybridity that combines elements of state, market, civil society and community simultaneously (Molina, 2009; Evers, 2005). This idea of hybridity focuses attention on the potential for engagement that is context specific and may enhance the capacity for co-production of welfare. The capacity to adjust one's logic may allow for a broader base for engagement and in turn, a more comprehensive solution for welfare. Nonetheless, regardless of the rationale for welfare, or decisions about implementation, vulnerabilities can still exist. This makes the mitigation of potential vulnerabilities an ongoing process. The potential for hybridity in engagement of welfare production as well as areas of continued vulnerability are aptly demonstrated in the analysis of the Ismaili Imamat, Ismaili community institutions and AKDN case studies. 


\section{Method and Outline}

My method is a case study approach using the example of the Ismaili Imamat, Ismaili community Institutions and AKDN. These include an evolving international nonstate cluster of institutions that are directed by the Imamat level. In this context, the Imam takes on the obligation of welfare with Ismailis giving their allegiance to the Imam and rendering service for implementation. Also, the focus is on fostering an ethic of selfreliance and independence at the community level and within the broader context of AKDN. The scope of Imamat activities span international, regional, national, and community levels.

I will provide background information of the Ismaili conception of welfare by focusing on the period of 1905-2010 in Ismaili history. This time period will provide a sense of the evolution of both communal and broader based initiatives. Since the Ismaili community is dispersed over twenty-five countries, there was a need to narrow the focus for the purpose of this dissertation. I am utilizing a two-country approach, whereby the Ismaili case is examined in a developed and developing world context. It allows for an examination of the Ismaili community in different contexts and how this affects community structures, connections with the state and implications for individuals that are vulnerable. I decided to focus my analysis on Canada and Tanzania because of previous research examining the Ismaili community in both these countries (Matthews, 2007; Kaiser, 1996; Kaiser, 1995; Kaiser, 1994; Dossa, 1985; Nanji, 1974 among others). This will provide an opportunity to build on previous research. Also, Ismailis have migrated to Canada from East Africa since the 1960's, and the Canadian International Development Agency (CIDA) has funded projects led by the Aga Khan Foundation Canada (AKFC) in 
Tanzania. Also, it allows for a comparison of how the Ismaili community Institutions (i.e., Council and Boards) and formalized Institutions (i.e., AKDN) engage in welfare production in each country.

As discussed, the focus of mainstream welfare state literature is on the predominance of the national level in understanding welfare production, and this has its limitations when we consider the growing importance of supra-national levels (European Union, IMF, World Bank and other international organizations) as well as sub-national levels, as more forms of welfare services are decentralized (Davis, 2001). This brings to the forefront the methodological importance of understanding scale when examining welfare production. In essence, understanding scale provides an opportunity to explore how relations are "construed" and "contested" at the global, national, regional, local, and community levels (Mahon, 2003). It allows one to examine the potential for multiple and overlapping sites of welfare production as well as new points of contact and collaboration. As noted by Mahon (2003, p. 2):

Contemporary developments, however, throw into question the utility of a singular focus on the national relative to the supra- and the sub-national scales. Welfare regimes are thus deeply implicated in a (complex and contested) process of "rescaling" [...].

This insight is important when examining the role of "hybridity" in understanding welfare production as it forces one not to assume that a particular "logic" (Evers, 2005) should be privileged. Many configurations are possible in welfare production without the assumption that if welfare is produced at a particular site it necessitates a certain logic. This allows for the possibility of collaboration and co-production on multiple fronts. Although Peck (2002) acknowledges the importance of scale and scale relations, he points to the importance of understanding these relationships within the context of 
institutions and a politically mediated environment. For example, in welfare/workfare transition, he notes that the nation-state cannot be taken out of the picture while privileging the local and global scales. Rather, the state can take on managerial and "orchestration" roles in various policy environments (Peck, 2002). However, as with scale and not conceiving of hierarchies as mutually exclusive (Mahon, 2006), it is important not to limit the managerial and orchestration roles in various policy arenas to the state. This allows for the potential of a mixed logic configuration that is not necessarily the state but may act as a lynchpin for welfare production. This comprehensive understanding of scale and hybridity allows for the possibility of a methodologically innovative way of thinking when it comes to welfare policy design and delivery.

The data necessary to tackle the questions posed included a combination of published material and interviews. The published sources include scholarly works, AKDN reports and publications, websites, newspaper and magazine profiles. I conducted interviews with thirty-eight individuals. These individuals were engaged in the governance and management of the relevant AKDN institutions as well as senior members of the National Council, Boards and Portfolios of the Ismaili community. As the focus of this dissertation was on the institutions themselves, interviewees were chosen based on their position in the relevant institutions. Some interviewees in the AKDN components were found directly through published reports while other individuals were contacted after receiving their contact information from those already interviewed. Interviewees for the community institutions were found by contacting the executive levels of the National Councils to explain the purpose of the study and then the contact 
information for the relevant Boards and Portfolios was provided. These individuals were then contacted to determine their willingness to participate. The data for this study included open-ended and semi-structured interviews using a combination of in-person and telephone interviews depending on the availability and location of the participant. Inperson interviews were conducted in Ottawa, Toronto, Nairobi, Kenya and Dar es Salaam, Tanzania. Telephone interviews were conducted with individuals in Geneva, those unavailable during my research visit to Tanzania, and individuals in other Canadian cities. The interviews were conducted in 2010 . The interviews were approximately one hour in length. Interviews were tape recorded and transcribed when participants agreed, and in other cases only written notes were taken.

As part of the consent process, interviewees were informed that they could decline to answer any question and were given the option for responses to be nonattributable. This was in an effort to provide a space for reflection given the potentially sensitive nature of questions around issues of welfare in a community that prides itself on self-reliance and independence. Thus, I wanted to ensure an opportunity for individuals to share information in a comprehensive way. However, if responses were specifically identified some individuals might have felt uncomfortable in doing so. The participants were also given the contact information of my supervisor and the University ethics Chair if they had any concerns or comments. The intention was to create an environment that would not only be beneficial for me as a researcher but also for the participants. Several interviewees commented that they were grateful for the opportunity to participate in the research because they often found the pace of their environments made it difficult to pause for reflection. 
As this study is qualitative in nature, it is important to keep in mind that inferences can often be more implicit. This can make issues of validity difficult to evaluate (Patton 1999; Palys, 1997; King et al., 1994). Furthermore, as pointed out by King et al., (1994) the procedures of qualitative research occur in a more private rather than public domain. This can make assessment of selection criteria, recording and processing data as well as the logic of conclusions less clear-cut (ibid.). There can also be limitations of generalization to other contexts and populations. Nonetheless, given the types of questions needed to understand welfare production, the topic under study will necessarily be less structured. To overcome many of these issues, I have tried to explicitly state my logic and rationale for inferences. In addition, I provide detailed background information for the case studies and make use of interviewee quotations to enhance the validity of the research.

According to Flyvbjerg (2006), we need to be cognizant that there is a tendency from a methodological perspective to privilege formal generalization as being the ideal form of knowledge accumulation. This assumption can put an unnecessary halt to complex questions that require more in-depth analysis. So there is a need to broaden our conception of knowledge accumulation and include methods such as case studies that do not neatly fit into the realm of formal generalization. Flyvbjerg states:

[...] formal generalization is only one of many ways by which people gain and accumulate knowledge. That knowledge cannot be formally generalized does not mean that it cannot enter into the collective process of knowledge accumulation in a given field or in a society. A purely descriptive, phenomenological case study without any attempt to generalize can certainly be of value in this process and has often helped cut a path toward scientific innovation. (2006, p. 227) 
Furthermore, Flyvbjerg points to the value of example in scientific development. He asserts:

Atypical or extreme cases often reveal more information because they activate more actors and more basic mechanisms in the situation studied. In addition, from both an understanding-oriented and an action-oriented perspective, it is often more important to clarify the deeper causes behind a given problem and its consequences than to describe the symptoms of the problem and how frequently they occur. $(2006$, p. 229)

An in-depth case analysis allows for a richer and more detailed understanding albeit more complex and dynamic form of data. However, it is from this wealth of information that key themes and insights can emerge (Patton, 1999), as was the case in this study of welfare production. Pal (2005) notes that case studies can serve to highlight policy relevant questions that can inform more practical advice. Furthermore, Pal highlights Yin's explanation of the importance of understanding the questions one is seeking to answer before deciding which method to use. Specifically, questions that relate to the how or why are more suited to case study analysis as in this research endeavour. The role of theory in guiding case selection is another key component, thus providing the opportunity to test ideas from theory.

The analysis of the Ismaili Imamat, Ismaili community and AKDN allows for a study of welfare on multiple scales, and it expands the logic potential of actors. For example, the Ismaili Imamat engages in welfare production at the international, regional, national, and community levels. The Imamat level analysis exemplifies an entity that has as part of its composition state-like qualities. This logic of hybridity allows for an analysis that is not confined at the state level, the usual locus for understanding welfare theory, nor is it limited to state "orchestrated" and managed relationships with the private sector or civil society. Rather, this case study allows one to delve into the pragmatic 
issues of how welfare can be managed by shifting the lens from a state-centric approach to one that is more fluid in its composition. In doing so, it provides a unique vantage point to examine problems and possible solutions related to welfare. Furthermore, given that the Ismaili Imamat and the Ismaili community have links in both the developed and developing world, it presents a unique opportunity to examine issues of welfare and social protection in a comparative manner. By looking at both the AKDN and the Ismaili Council structures, it allows for an understanding of communal arrangements as well as broader initiatives.

The dissertation is composed of three main parts. Chapters One, Two and Three provide the theoretical framework and background information on the Ismaili Imamat, Ismaili community, and the Aga Khan Development Network. Chapter One, the current chapter, provides an introduction to the dissertation and examines the key theoretical frameworks of relevance (i.e., welfare state theory and extensions, state-civil society frameworks, and transnational networks) and how it relates to the Ismaili Imamat, Ismaili community and AKDN. Chapter Two provides an overview of the role of the Ismaili Imam and the Ismaili Community and examines the impetus for welfare production. Chapter Three delves into the historical underpinning for the formulation of AKDN and outlines its current structure. The second component of this dissertation focuses on the two case studies. Chapter Four brings to the forefront the shifts in demographics within the community in Canada, and the implications for community structures as well the potential for leveraging traditional state and external entities. Chapter Five focuses on the implications of shifting from community based structures to broad based initiatives in Tanzania. As well, the implications of a logic of hybridity and capacity for sectors to 
break out of traditional sector confinements are explored in both case studies. Chapter Six summarizes the findings in the case studies, highlights the theoretical contributions, and provides suggestions for future research.

\section{Contribution}

This research makes several contributions. It will broaden our definition of welfare and expand the sites where welfare production is thought to occur. Also, it will have practical insights for policy coordination and co-production. Currently, the focus of welfare state theory is on individual states and the comparative dimensions of their welfare regimes, and the role that global networks play, is not fully acknowledged. In addition, instead of examining state, market and civil society as silos, other hybrid configurations come to the forefront. Much research frames questions related to welfare production as how the state manages private sector and civil society engagement. This assumes that the logic of state, private sector, and civil society are immutable instead of allowing for the possibility of a logic of hybridity (Molina, 2009; Evers, 2005). For example, the AKDN may seem to be a community driven organization, but a closer look unearths a more complex Imamat level that defines the vision and strategic direction of AKDN while members of the Ismaili community engage in implementation and resource generation. Also, given that the capacity of the Imamat level is not to be confined to a particular logic, it allows for engagement on multiple fronts including accessing funding from wider sources and creating partnerships with the private sector and government. The research will provide useful insights regarding the sites of welfare production and relevance of social policy development within both a developing and developed world 
context. It will examine the challenges of taking a self-reliance and independence based approach, particularly for those that are the most vulnerable within a community. This brings up issues of where resources are concentrated and how it compares with a more rights based approach. By examining the AKDN in the broader international context, as well as the two case studies at the national level, and the Ismaili community at the local level, I introduce a multi-scalar analysis. This will provide a more comprehensive understanding of welfare production at the global, national, and local levels. As well, the importance of a regional perspective when addressing issues of welfare is highlighted. It becomes clear that welfare needs and sites of production are not limited to individual states but transcend national boundaries, and are part of a more complex network of actors and organizations. These findings will contribute to welfare state theory, state civil society relations as well as development studies.

\section{Theoretical Framework}

The need for welfare production has been centrally linked to countering the effects of commodification in the marketplace (Esping-Andersen 1990; 1994; 1999). As well, the focus has been on the state's role in buffering the impacts of the market.

Polanyi's concept of an economy being embedded in society draws one to examine what role institutions play in the economy and whether there are non-economic reasons for engaging in a market system. As noted by Polanyi, one needs to examine whether "the running of society" can be "an adjunct to the market," thus "instead of economy being embedded in social relations, social relations are embedded in the economic system" (2001, p. 60). When economic rather than social needs are at the 
forefront, there is a sense that the market can exist in only one way regardless of context. However, Polanyi argues that society has a choice in how the market system functions and emphasizes the role institutions can have in directing the market. Thus, the market should not be seen as superior to society, but subordinate. Polanyi asserts that "to allow the market mechanism to be the sole director of the fate of human beings and their natural environment indeed, even the amount and use of purchasing power, would result in the demolition of society" (2001, p. 76$)$.

The current conceptions of welfare state regime theory provide various opportunities and challenges in understanding the production of welfare. The study of welfare regimes has traditionally focused on welfare states within the OECD with an emphasis on the "state-market nexus" (Davis, 2001). Even so, the family sometimes has been considered a sphere where welfare production takes place. Thus, it extends the "dyad" of the state-market to include the "triad" of state-market and family (Jenson \& Saint-Martin, 2003; Esping-Anderson, 1990). The key underlying assumption of why welfare production is necessary in the first place remains as a way to temper the effects of a dependence on a "commodified" labour market. As such, social welfare policy is focused on providing ways for "decommodification", and incorporates the degree to which rights and exemptions are articulated (i.e., unemployment insurance, pensions etc.). (Esping-Andersen, 1990, p. 22; 1994; 1999). However, as argued by Esping-Anderson, the welfare state is seen, "not just [as] a mechanism that intervenes in, and possibly corrects, the structure of inequality; it is, in its own right, a system of stratification" (1990, p. 23). 
Welfare state regime types articulate the different arrangements between state, market and family in the provision of welfare. The clusters include the "liberal" welfare state, "in which means-tested assistance, modest universal transfers, or modest socialinsurance plans predominate" (Esping-Anderson, 1990, p. 26). Furthermore, EspingAnderson notes how strict entitlement rules often create an us-versus-them mentality that is linked to issues of stigma (1990, p. 26). The conservative regime is described in contrast to the liberal welfare state. Esping-Anderson writes, the "obsession with market efficiency and commodification was never preeminent and, as such, the granting of social rights was hardly ever a seriously contested issue" (1990, p. 27). The "social democratic" state is attributed with the principles of "universalism and decommodification" (ibid.). At the forefront is ensuring equality and striving for higher standards rather than focusing on minimal needs (ibid.).

The emphasis on decommodification was tempered by Kolberg and Kolstad (1992) who argued that the role of the state is not just to mitigate the effects of the market by engaging in decommodification measures, but that it also has a dual role "of both decommodification and commodification" (p. 173).

Sellers and Lidstrom argue that countries with pre-existing strong local governments with strong local capacity in fiscal and political administration tend to possess the so-called social democratic welfare states (2007, p. 626). This brings into question the national level fixation in determining regime type. Furthermore, the welfare regime types are premised on the notion of a fixed logic of a particular welfare regime. However, Bannink and Hoogenboom (2007) question this rigid conceptualization and argue that welfare states "are often hybrid, since they consist of various risk approaches 
which in themselves may be made up of various arrangements, each with their own allocation mechanism and coordination" (p. 31). This idea of hybridity will also be explored with respect to the various sectors within the welfare-mix.

Another area that is underdeveloped is the role of community in welfare production. The idea of a "welfare diamond" (Evers et al., 1994, p. 4) helps expand the scope for understanding welfare production (also see Graefe, 2004; Jenson \& SaintMartin, 2003). As described by Jenson and Saint-Martin (2003):

[...] the architecture reflects decisions about "how to produce welfare" in any country, that is, whether via purchased welfare (markets),via the reciprocity of kin (families), via collective support in communities (voluntary sector), or via collective and public solidarity, that is state provision. The welfare architecture depends to a large extent on choices made about how to structure the responsibility mix of a citizenship regime. (p. 80)

Wood and Gough (2006) also note the importance of the community level and examine whether community involvement leads to further engagement or disengagement from the state when it comes to welfare provisions. As such, added to the triad of statemarket-family is the community element, which includes community organizations and NGOs (ibid.). In addition, Wood and Gough include a supranational component whereby state-market-community-household is considered at the domestic and supranational level (ibid.).

Another aspect to consider is the difference in developed and developing world contexts with respect to social protection. As described by Gough (2004), social policy in developed countries tends to have at the core, a number of assumptions regarding the state, labour and financial markets, namely, a "legitimated state", "pervasive labour markets" and "sophisticated financial markets" (p. 21). In essence, the assumption is that 
you are dealing with an autonomous state in a capitalist context (ibid.). This has a bearing on where the sites of welfare production are expected. So, as argued by Gough (2004) when examining developing countries, there is a need to re-examine the assumptions regarding the state, labour and financial markets. Haggard and Kaufman (2008) go beyond the developed industrialized countries and focus on the various development routes of middle-income countries and their impact on the types of social policy reform that emerge. Rudra (2007) highlights the need to pay attention to the differences in the political economies of less developed countries and the impact this has on types of welfare regimes that emerge. Deacon (2003) notes the importance of understanding the welfare strategies of the middle classes in developing countries, and the role private markets play in health and education. As well, the effect this has on achieving broad based equitable social provision needs consideration (ibid.). According to Gough (2004), the validity of a state-centric approach that is the focus welfare theories in developed countries needs to be re-evaluated, especially for developing world contexts. In so doing, a more comprehensive range of government and non-government mechanisms for social support come to the forefront (Gough, 2004, p. 22). As well, the possibilities of regional approaches for welfare come into the mix (Gough, 2004; Deacon, 2003). As summed up by Wood and Gough (2004), "neither markets, nor states, nor communities alone can provide an adequate framework for meeting human needs" (p. 312).

The dominant actors in conceptions of welfare have been the state, market and to some extent family, and civil society. However, even in this so-called extension to a "diamond", the interconnection of all segments, including community, have not been adequately studied. For example, often the connection is seen as a zero sum game 
whereby if the third sector is engaging in aspects of welfare then the state is seen to have downloaded its responsibility, or one segment is positioned as better suited to produce welfare because of issues of cost and efficiency. Also, the logic of the different segments of state, market, and civil society is often conceptualized as being fixed. The type of relationship between state and non-state actors is premised on the assumption that each of these segments has its own unique DNA. However, as argued by Evers (2005), the interplay of the so-called sector logics can influence each other. As a result, there may not be "clear-cut" segmentation, but rather the potential for a logic of hybridity.

For example, Evers (2005) contends that the distinctiveness of elements of the welfare-mix (i.e., state, market, civil society) may not be as "clear-cut" as previously conceived. He asserts:

There are, however, indications that the traditional clear-cut separation of market based, state-based, and civil society bound/third sector-based service units has become increasingly insufficient; instead, one faces service systems and institutions that are shaped simultaneously by all three possible sectors, their values, and their steering mechanisms. (p. 738)

Evers delineates the concept of hybrids as being "about the potentials, risks, and tensions of an increasing intertwining of components and rationales as they are linked with the state, the market, and civil society and its networks" (pp. 741-742). These hybrid organizations are often classified as "social enterprises" (ibid.). Molina (2009) argues that there is a need to a focus on the processes of social innovation, as this allows for consistency in understanding hybridity. The logic of hybridity is seen as what can be applied to "sectoral spectra" rather than being limited to a particular organization (p. 17). Molina defines the criterion of hybridity as " the degree to which organizations of one sector implement motivations and activities that broadly pertain to the main purpose of 
organizations in another sector" $(2009$, p. 18). Although the concepts of hybrid and logic of hybridity are used to understand the processes of social innovations, there is the potential to miss the important contributions of in-depth studies that examine the internal dynamics of institutions that are engaged in degrees of hybridity. This is demonstrated with the case of the Imamat and the institutions of AKDN and at the Ismaili community level. Therefore, the concepts of hybridity and the logic of hybridity are used in this dissertation as a means for understanding the orchestration and management of welfare production in general terms rather than limiting the analysis to the processes of social innovation.

Fowler (2000), in his examination of non-governmental organizations which are engaged in international development, proposes a "fourth position" to conceptualize the relationship with other sectors. He articulates an intermediary position whereby these organizations are:

$[\ldots]$ more than states and markets, it seems more sensible for them to capitalise fully and effectively on this fact than to fight it. In doing so, they become entities that today's management science would regard as complex, purposeful systems. In this case, they contain characteristics commonly associated with each of the 'traditional' three sectors, but cannot be fully understood or analysed from within the framework of any one of them. [...]. In short, this type of NGDO [non-governmental development organizations] 'belongs in' and is anchored to civil society, but is not solely 'of' civil society because it purposefully inhabits and works in the space and interaction between civil society, state and market. (p. 598)

Furthermore, as described by Fowler (2000), it is when organizations are willing to embrace this so-called "fourth position" that they will be in a "pivotal position to accelerate and direct change in the $21^{\text {st }}$ century" (p. 601). In essence, it is “ $[\ldots]$ the competence to speak different 'sector languages'; engage across institutional boundaries and foster inter-organisational linkages" (p. 598). It is this understanding of a "complex, 
purposeful system" which is not confined to one segment that will be explored in this dissertation.

Pinning down the operational definition or name, for that matter, of a civil society bound/third sector is not a straightforward task (Harris, 2006; Najam, 2000; Scholte, 2002). As described by Najam (2000), scholars and practitioners focus on "different aspects of its essence" (p. 378). For example, Scholte's (2002) definition of civil society excludes organizations that do not seek to "shape policies, norms and structures in society at large" (p. 147). As there is the potential to straddle multiple logics of state, market and civil society bound/third sector, devising a neatly packaged definition is not the aim here. Nonetheless, a broad based understanding of this sector will provide a mental anchor. As such, for this dissertation, the understanding of this sector will encompass a range of organizations that vary in size and governance structures, are separate from government, and are predominately not for profit (Phillips \& Orsini, 2002; Najam, 2000).

Several formulations emerge when examining the relationship of state and civil society in the literature. One is focused on a relationship that is to some extent adversarial whereby civil society organizations keep the state "in-check." This could take the form of advocacy groups/coalitions in various areas of policy (see Keck \& Sikkink, 1998; Cohen \& Arato, 1994). The second stream focuses on partnership, for example, service delivery as well as contributing to aspects of governance. For example, Jessop (1999) notes the increasing government interest in the 1980s to determine how public-private partnerships could contribute to public policy initiatives. However, Jessop argues that governance failure is part and parcel of such relationships, and there is a need to understand issues of co-ordination and have a level of "commitment to participatory politics" (1999, p. 12). 
Finally, we see a collaborative relationship, but also elements of advocacy. This entails a robust engagement of ideas and interests with the state. Thus, a constant tension is in place. Evers aptly describes this as follows: "this relationship between the public sector and the political majority on the one hand and non-profits and other organizations on the other can be referred to as conflictive co-operation" [emphasis in original] (1995, p. 166).

Najam (2000) proposes a model for understanding the different configurations that emerge based on the means and ends of government and non-governmental organizations. He describes the model as "the four-c's of third sector-government relations", whereby there is cooperation when "seeking similar ends and means"; confrontation when "seeking dissimilar ends with dissimilar means"; complementarity where there are "similar ends but dissimilar means"; and co-optation when there are "dissimilar ends and similar means" (p. 375). Thus, the focus is on "strategic institutional interests of both" state and non-state actors in a given interaction (Najam, 2000, p. 376). The environment for engagement is also important. For example, Clark (1995) argues that the capacity for non-governmental organizations to contribute to development is linked to having an enabling environment fostered by the state. Furthermore, he notes non-governmental organizations can serve as a bridge to help articulate needs and enhance participation in development.

An aspect of the relationship between state-civil society that will be examined in this dissertation is the potential for co-production in areas of welfare. At this stage, unpacking the concept of co-production may be useful in understanding the type of relationships between state and civil society in welfare production. Ostrom (1997) examined the synergies that could occur between government and citizens in the 
production of services. Ostrom asserts 'the 'regular' producer of education, health, or infrastructure services is most frequently a government agency. Whether the regular producer is the only producer of these goods and services depend on both the nature of the good or service itself and the incentives that encourage the active participation of others $[\ldots]$ Coproduction implies that citizens can play an active role in producing public goods and services of consequence to them" (1997, p. 86). Peter Evans (1997) highlights that "the combination of strong public institutions and organized communities is a powerful tool for development. Better understanding of the nature of synergistic relations between state and society and the conditions under which such relations can most easily be construed should become a component of future theories of development" (p. 204). For example, he points to the importance of embeddedness, in addition, to complementarity for co-production. This idea of somehow connecting "citizens and public officials across the public-private divide" (Evans, 1997, p. 180) allows for more fluidity than the usual rigid understanding of the state-society relationship.

Relating co-production to the provision of public services by voluntary and community organizations has led to further delineating the concept. For example, Osbrone and McLaughlin (2004) highlight that the voluntary sector in the United Kingdom might have been moving to co-governance, but there has been a shift to more co-production roles akin to being service agents of government in the delivery of public services. Brandsen and Pestoff (2006) further refine the types of cooperation between the state and the voluntary sector, to include co-production where the focus is on service delivery roles; co-management which entails a broader role in the area of collaboration with government; and co-governance denoting the role of the voluntary and community 
sector in policy formation and community governance (p. 497). Brandsen and Pestoff (2006) note that the concepts of co-production, co-management and co-governance are not mutually exclusive, so they retain co-production as an umbrella term for the different permutations (ibid.). For this dissertation, I explore the capacity for co-production and elements of co-management and co-governance. As well, the possible limiting factors of engaging in co-production and instead opting for a strategically tempered engagement with government will be explored.

The focus so far has been on the state and considering other actors involved in welfare-production. In addition, the possibility of a logic of hybridity that may help foster multiple points of engagement on relevant policy issues was introduced. However, the emphasis has been at the domestic level. The literature on transnational policy networks and considering a regional dimension helps orient us to actors both at the domestic and international levels. This allows us to explore how ideas and interests may be transmitted on various policy issues that could extend to aspects of welfare production (see Yeates, 2008; Wood \& Gough, 2006; Stone, 2004; Scholte, 2005; Stone, 2001; Finemore, 1993). As noted by Yeates, "social policy analysis is best understood through the lens of methodological transnationalism. Given the prevailing social policy paradigm, this approach presents important challenges as it involves rethinking the construction of fields of enquiry and revisiting conceptual, theoretical and methodological frameworks developed over many decades" (2008, p. 289).

The state is the centre from which welfare institutions are anchored within the confines of welfare state literature. However, in the context of globalization, the state is no longer the only nexus, but rather "state control over space and time is increasingly 
bypassed by global flows of capital, goods, services, technology, communication and information" (Castells, 2004, p. 303). March and Olsen (2006) highlight the influence of the flow of issues and networks across borders when examining identities and note that "there is no single centre with control over education, socialization and indoctrination" ( $\mathrm{p}$. 9). According to Scholte (2005), there is more layering of governance, and he argues that this has led to states sharing tasks of governance with relatively autonomous sub-state and trans-world agencies (p. 157). This layering could potentially include regional and transnational configurations. Stubbs (2003) argues that although there are progressive aspects of international non-state actors in social development policy, the focus is on efficiency, outcomes, and programmes versus projects. He suggests this requires an examination of the role of subcontracting in aid and development as it can have implications for local capacity. There is also a tendency when examining international NGO's to segment and separate out the logics of government, non-government, and profit-seeking entities. However, there is some acknowledgement that the sectorial divides are blurring (see Florini, 2006, p. 686).

Hall's (1993) engagement with the concept of "social learning" draws attention to the developments outside the state that has influenced policy and how ideas can connect the state, non-state actors and maybe even international organizations. Furthermore, he underlines the importance of not "positing too rigid a distinction between the state and society and an insistence on the autonomy of the state" (p. 292). This marketplace of ideas need not be limited to non-state actors within a particular state, but it can be expanded to networks that comprise representatives of governments, international organizations, civil society associations, or business groups, to name a few (Keck \& 
Sikkink, 1998). As articulated by Stone (2001), networks provide sites for iterative interaction, exchange of information, debate, disagreement, persuasion, as well as the search for solutions (p. 36). Thus, ideas can flow within networks as well as be spread beyond the network (ibid.). Many policy problems today have a strong transnational character that reinforces the rationale for sharing information, exchanging ideas and collaboration (Stone, 2001).

Complex policy issues such as welfare production necessitate an in-depth examination of key strategies that traverse sectors and scale. It brings to the forefront some important questions. For example, how can a logic of hybridity assist in understanding the different components of the welfare-mix and enhance the potential for engagement? What impact does having a transnational perspective have on decisions regarding welfare? Is there a need to consider the balance between social and economic priorities? And how does moving from community welfare production to a broader base affect issues of vulnerability at the community level?

The importance of understanding these cross-cutting issues in an integrated way necessitates examining them in a manner that may be methodologically complex, but it will provide invaluable insights to pressing issues of welfare production. The unique case study of the Ismaili Imamat, Ismaili community institutions and AKDN will be the microcosm for knowledge accumulation in this important policy area.

\section{Theory Link to Case Studies}

Using the case examples of the Ismaili Imamat, AKDN and the Ismaili community institutions I will explore the potential of expanding the conceptions of 
welfare, the rationale for welfare, and understanding how it is produced. As well, the potential for a logic of hybridity that encapsulates aspects of state, market and civil society is explored. As well, this dissertation will highlight the vulnerabilities that may come into play regardless of the conception of welfare or how it is implemented.

The Ismaili community is based on its allegiance to a living Imam, and the authority of the Imam is central to the community. The Imam's progeny is traced to the Prophet Mohammed through his Cousin Ali who married the Prophet's daughter Fatima. There have been several schisms within the Shia tradition because of issues related to succession of the Imamat. The focus in this dissertation is on the Nizari Ismailis whose Imams trace their lineage in history to Imam Nizar, and then back to the family of Prophet Mohammed. This point will be explored in more detail in the Ismaili background chapter.

Within the Ismaili community there is an ethic of voluntary service to the Imam and sharing one's time and knowledge within the Ismaili community and broader society (Daftary, 1998, p. 201). In addition, issues related to the integration of Din (faith/spirituality) and Dunya (society/the material world) are at the forefront, placing an emphasis on an ethical responsibility. As explained by the current Aga Khan:

The ethics of Islam bridge the realms of faith on the one hand and practical life on the other - what we call Din and Dunya. Accordingly, my spiritual responsibilities for interpreting the faith are accompanied by a strong engagement in issues relating to the quality of life and well being. This latter commitment extends not only to the Ismaili community but also to those with whom they share their lives - locally, nationally and internationally. (AKDN, 2007i)

The community and religious affairs are maintained by a comprehensive Council system and other entities with the Imam as the pinnacle. However, the communal entities 
are for the most part institutionally separate from the non-denominational formal institutions of the Aga Khan Development Network (AKDN).

Sir Sultan Muhammad Shah, Aga Khan III, the forty-eight Imam of the Nizari Ismailis focused on the modernization of his community (1885-1957). The areas of focus included education, social welfare, and the role of women (Nanji, 1974). Several formal institutions, predominately in India and East Africa, were created in the areas of health, education, and economic development. The focus of these institutions was to benefit the Ismaili community and later was opened to broader segments of the population.

The emphasis on modernization policies as well as the initiation of new institutions continued with the forty-ninth Imam, Aga Khan IV (1957-present). Ismaili emigration to Europe, United States, and Canada necessitated further expansion of the Council system. As the scope of the various social, economic and cultural institutions expanded, Aga Khan IV shifted his approach to the formal and professional, nondenominational Aga Khan Development Network (AKDN).

The social component of the Network focuses on projects in health, education, planning and building, and humanitarian assistance. Economic development came to encompass projects in financial services, media, aviation, industrial ventures as well as tourism promotion. Finally, the culture component focuses on the preservation and regeneration of cultural heritages of Muslim societies. A more detailed description and analysis of the Ismaili Imamat, the Ismaili community and AKDN are provided in subsequent chapters of this dissertation.

The first point of access for the theoretical links is the Polanyian conception of the capacity for the economy to be embedded in society, whereby individuals in society 
have a role in deciding how to incorporate the market within society (2001). According to Polanyi (2001), groups in society can be part of "countermovements" working together to meet individual and collective needs and respond against the effects of a self-regulating market. These "countermovements" are the mechanism for creating a zone of selfprotection. This assumes a highly interconnected society, but it is unclear what societal mechanisms are in place to bring diverse groups together to react against the effects of the market. However, there are examples such as Occupy Wall Street and the Arab spring movements that tap into this notion of "countermovements". As well, for Polanyi, the state has an important role to play in the intervention of markets to ensure that society can adjust to changes as well as mitigate the effects of comodification of land and labour.

This conception of the embeddeness of the market in society may be useful in examining the principles of AKDN, the role of the Imamat and members of the Ismaili community in welfare. For example, there is an attempt to approach development from an integrated perspective with the components of social, economic, and culture encompassing aspects of well-being. In addition, problems faced by individuals are seen as cross-cutting. However, the actual level of integration of the social and economic components of AKDN, the connection of the Ismaili community with AKDN, and the interconnection within the Ismaili community points to a more complicated relationship. For example, it could be argued that the level of connectivity of the Ismaili community is actually between the individual Ismaili and the Imamat level (based on the idea of allegiance). So although the Imamat level may strive for high levels of connectivity, as a side-effect of allegiance, the differences in socio-economic status, cultural background, and national realities may make networked connections at the community level more 
elusive than expected. As will be demonstrated in the case studies, there has been a shift in focus from the Ismaili community level to a broader based mandate for the formal institutions. The increased inclusion of constituencies outside the Ismaili community has led to a repositioning of priorities based on new needs.

Welfare state theories have focused on the role of the state in decommodification. However, as discussed, Kolberg and Kolstad (1992) argue that the state, in fact, has a dual role "of both decommodification and commodification" (p. 173). So the state is engaged in simultaneously mitigating the effects of the market as well as engaging with the market. Similarly, the AKDN has components that are engaged with the market for profit purposes, and it has the social components that to some extent serve to temper the effects of the market. Other conceptions looked at elements beyond the state to include family and the informal/community third-sector, and this pushes the nexus of welfare, from one predominantly focused on state and market, and expanding it to a "diamond" (see Wood \& Gough, 2006; 2004; Graefe, 2004; Jenson \& Saint-Martin, 2003; Evers et al., 1994).

The "welfare diamond" illustration provided a useful way to articulate "decisions about 'how to produce welfare' in any country" (Jenson \& Saint-Martin, 2003, p. 80). The designation of segments provided a good starting point for understanding the complexity of welfare production. I am arguing in this dissertation that the Imamat level is taking on a "fourth position" (Fowler, 2000) that brings to bear the capacity to function in a space that is connected to aspects of state, market, civil society/third-sector, and community, but is not necessarily a part of those sectors. In fact, there is the capacity to work above the entanglements of a particular sector. As well, the lines between segments 
are not necessarily clear-cut (Evers, 2005). However, the initial "welfare diamond" analysis provides a useful composition to understand the engagement of the various Ismaili institutions and the broader institutions of AKDN. A key aspect of the welfare "diamond" is understanding the responsibility of the various sectors and the degree to which engagement occurs by a particular sector in producing welfare (Jenson \& SaintMartin, 2003). The Ismaili community approach to social provision has been affected by their position as a minority community and sometimes in history being denied access to welfare services. This has led to include a strong focus on self-sufficiency and independence. As such, when you look at the various components of the "welfare diamond", the Imamat and to some extent the Ismaili community focus, has been on ensuring control and access to the various sources of quality of life.

The Imamat level is engaged in the provision of health and education that is purchased and in supporting capital markets via economic development initiatives. Reciprocity is expected at the community level and is demonstrated by having a donation driven welfare mechanism to address issues of individual need. The aspects of collective support are interesting because the Aga Khan Foundation (AKF), a component of the $\mathrm{AKDN}$, has taken on the role of encouraging civil society and stressing the importance of the voluntary sector in buttressing the state, especially in areas of welfare. So there are components of the AKDN that take on engagement of collective support in communities beyond the Ismaili community. Finally, in the area of state provision, the Imamat has a point of access because of its capacity for a state logic and the protocols it has in place regarding issues of health, education, and economic development. Thus, there is a sense 
that the different components of the community level and broader initiatives are to some degree traversing all the components of the "welfare diamond".

This idea of a logic of hybridity and what it means to be able to engage with, state, markets and civil society in areas of welfare production, and the capacity to embody a "fourth position" (Molina, 2009; Evers, 2005; Fowler, 2000) is a key focus in this dissertation. So in a sense, the Imamat level, and to some extent the AKDN, are positioned as intermediary entities that can interact with states because they take on qualities of a state and can engage with the market through its profit making entities. As well, there is a connection with civil society through its social endeavours. However, the Imamat level and the Network are not defined by any one sector.

The Imam's responsibility for a dual mandate and the need to shift focus from the community level to a broader base brings to the forefront how issues of vulnerability are managed within the Ismaili community context. As well, I will examine the difficulties that arise when welfare at the community level is donor-based and can be susceptible to financial and human resource limitations. The expectation of individual Ismailis to be self-sufficient and addressing any remaining vulnerabilities at the Ismaili community level may provide a level of confidence to pursue broader based development. However, there may be an assumption that concepts of Din and Dunya (link between spiritual and material) are centre stage at the community level, so there is a strong level of interconnection. The strength of this interconnection, however, may be superseded by the link between the individual and the Imam. Also, although voluntary service has benefits at the community level, the rationale for engagement is linked to serving the Imam. The focus on self-reliance and independence in such a framework brings to the 
forefront the potential for individuals to slip through the cracks when others within the community have achieved a certain socio-economic status.

The various economic and social reasons for welfare production may provide new insight to possible co-production configurations between state and other so-called civil society bound/third sector entities. Therefore, an understanding of the capacities and limitations of welfare production by various actors allows for a more comprehensive configuration. In addition, the overlaps that may occur between state, market and civil society could provide a more nuanced understanding of co-production.

As well, an understanding of the strategic rationale for engagement (Najam, 2000; 2006), can help explain why an organization such as the AKDN may foster formal relationships with governments in the form of protocol agreements but, at the same time, take a tempered approach in its partnerships with government. Finally, the structure of the Imamat, $\mathrm{AKDN}$, and the Ismaili community institutions necessitate a comprehensive methodological viewpoint that incorporates scale and transnationalism to the study of welfare production. This will serve to provide a more robust understanding of an important area in social policy.

Using the theoretical framework outlined in this chapter, I will explore in more detail, the background of the Ismaili community, AKDN, and the role of the Imamat in welfare production. The case studies will bring to life issues of welfare production, the challenges of a hybrid formulation, the potential for links with the state as well as the differences in social protection in a developed and developing world context. 


\section{CHAPTER 2: ISMAILI HISTORY AND BACKGROUND}

\section{History and Background Overview}

The makeup of the Nizari Ismaili Muslim community today is reflective of the various countries where they live, including regions in Asia, the Middle East, Africa, Europe, and North America. They come from different cultural backgrounds and speak various languages. The population of the Ismaili community throughout the world has been estimated to be as high as twenty million (Williams, 1988 as cited in Kaiser, 1996, p. 41). However, a more non-committal Ismaili population estimation of "several millions" has been maintained elsewhere (Daftary, 1998, p. 4; Daftary, 2011, p. xiii). As with other Shia Muslim communities, the role of the Imam is central and rights to that leadership emanate from the link to the Prophet Muhammad's household (ahl al-bayt) (Daftary, 1998, p. 1). After the death of the Prophet Muhammad, his son-in law Ali was considered the first Imam (leader/guide). However, the succession of Imamat has not been without contention, and this has resulted in major and minor splits within the Shia tradition (ibid.). One of the major splits was that between the Nizari Ismailis and the Ithna ashariyya. The Nizari Ismaili Imams trace their lineage of the Imamat from Prophet Mohammed to the current Imam, His Highness Karim Aga Khan IV, the forty-ninth Imam (Nanji, 1974, p. 124). The Ithna ashariyya assert that their last Imam is in "concealment" and will reappear near the time of Judgment Day (ibid.). The Ismaili Imams resided predominately in Persia in the early 19th century. However, Aga Khan I (the forty-sixth Imam) was the first Imam who relocated to India in 1842 after the defeat of the British forces in 
Kabul and Qandahar (Daftary, 1998, p. 197). It was in India that Aga Khan I and his "cavalry" were instrumental in the incorporation of Sind to British India (ibid.). Aga Khan I was compensated for his services to the British with an annual pension. Also, he received protection from the British in India, which further served to enhance his status (ibid.).

There were several key court cases that have challenged the legitimacy of the Ismaili Imams and their rights to leadership and ownership of communal property. The challenges were filed in 1851 and 1866 with the Bombay High Court (British India) and were adjudicated by the British judiciary (Hirji, 2011, p. 134). In the first case the ruling went against Aga Khan I, and the customary practice of the Khojas was upheld (e.g., election of leaders versus appointment, ownership of religious dues and communal property) (ibid.). The Khoja Ismailis in India were originally Hindus that converted to the Ismaili tradition in the middle of the ninth century A. $\mathrm{H}^{1}$./fifteenth century A.D. and continued for several centuries after (Asani, 2001; Daftary, 1998, p. 4). The Imams at the time relied on a da'wa (i.e., missionaries) to convert new followers.

A formalized effort was made by Aga Khan I in 1861 to establish his authority and quash any dissent by circulating a document outlining the religious identity of the Ismailis in India, and then asking followers for a formal declaration of their allegiance and loyalty to the Imam (Daftary, 1998, p. 198). A number of individuals did not sign the document, and in 1866 there was another court challenge to the Imam's authority. However, in this instance the authority of the Aga Khan and his right to communal property and religious dues was upheld (Hirji, 2011; Daftary, 1998). This case was at a

\footnotetext{
${ }^{1}$ A.H is the abbreviation for After Hijra that is used in Muslim lunar calendars. It bases dates after the migration of Prophet Muhammad from Mecca to Medina (i.e. 622 A.D).
} 
time when the British were seeking more clarity regarding religious groups in India (Hirji, 2011, p. 135). In essence, the decision allowed the British to ensure a single point person regarding the governance of the Ismaili community. The community group was designated the Ismaili Shia Khojas. Those individuals not willing to acknowledge the supremacy of the Imam either followed Sunni Islam or, subscribed to the Khoja Ithnaashari community (ibid.). Another challenge in 1905 (Daftary, 1998) occurred during the time of Aga Khan III and will be discussed in the context of the development of the Ismaili Constitution.

Nizari Ismaili Imams have not always been accessible to their followers, so issues regarding identity were not clear-cut. Nonetheless, the eventual control over the Ismaili community was further cemented when the Imam took full control of the traditional Khoja communal hierarchy that was already in place (Asani, 2001, p. 159; Daftary, 1998, p. 198). The need for asserting the identity of the Ismaili community was also important because various segments of the community and Imams concealed their identity (taqiyya) as a form of self-protection due to fears of persecution (Daftary, 1998, p. 170). This included efforts after the defeat by the Mongols 654 A.H./1256 A.D. and at various times in history in response to possible persecution by other Muslim groups (ibid, p. 4). Aga Khan I died in 1881 and was succeeded by Aga Khan II, but he was Imam for only four years and died in 1885 (Daftary, 1998, p. 199). Although issues of identity were challenged during the time of Aga Khan I and Aga Khan III, the capacity to be fluid in interpreting identity and engaging with the environments where Ismailis find themselves has been an important asset. The Imams have shared their guidance on spiritual and material aspects of life through their firmans. These are verbal or written directives and 
are intended to provide guidance in areas such as education, social welfare, religious practices, and social relationships (Daftary, 1990, p. 526). Adatia and King (1969) note, "firmans apply the faith to different times and circumstances" (p. 182). As such, "the details may change; the spirit remains the same" (ibid.).

Sir Shah Sultan Mohamed Shah, Aga Khan III succeeded to the Imamat in 1885 at the age of eight. It was during the Imamat of Aga Khan III that the residence of the Imam shifted from India to Europe. The relationship the Imams maintained with the British has been noted as being beneficial to Ismailis who lived under British colonial rule in India and later, in Africa (Daftary, 1998; Nanji, 1974). It was in the early $19^{\text {th }}$ century that Ismaili migration from India to East Africa began, first to the coastal region of Zanzibar (Daftary, 1998; Nanji, 1974; Walji, 1974). Aga Khan III focused on enhancing the welfare of the community in the areas of health, education, economic development, and he introduced modernization polices. Aga Khan IV became the Imam of the Nizari Ismaili community in 1957. Migration of Ismailis to countries in the West and access to regions like Central $\mathrm{Asia}^{2}$ created new challenges for Aga Khan IV regarding the management and organization his community. The professionalization of the health, education, and economic development entities continued with Aga Khan IV and gained new momentum with the consolidation of entities under the Aga Khan Development Network (AKDN).

\footnotetext{
${ }^{2}$ In the Ismaili Council and AKDN terminology Central Asia includes Afghanistan. The other countries referenced when referring to Central Asia include Tajikistan, Kyrgyz Republic and Kazakhstan.
} 


\section{The Link of the Imam and his Community}

\section{Imam as the Pinnacle}

The Ismaili Imam is positioned and accepted as being supreme in matters related to the community, be they religious or material. Supremacy is an underlining principle of the doctrine of Imamat. As described by Daftary (2001):

This doctrine, which has continued to occupy a central position in Ismaili theology, was based upon a belief in the permanent need of mankind for a divinely-guided, sinless and infallible (ma`sum) imam to act as the authoritative teacher and guide of men in all their spiritual affairs after the death of the Prophet Muhammad. Indeed, this imam was perceived as a charismatic leader possessing certain superhuman or divinely-ordained attributes. Entitled to temporal leadership as much as to religious authority, the imam's mandate did not, however, depend upon his actual rule over a state. (para. 5)

How this notion of a so-called divinely inspired Imam is understood today at the

Ismaili community level is not the focus of this dissertation, but attempts have been made in other studies to encourage a level of reflexivity at the individual level on this point (see Matthews, 2007; Dossa, 1985). The idea of the Imam not being confined by the boundaries of a state is important and will be explored later in more detail.

The authority and supremacy of the Imam is clearly outlined in the Ismaili Constitution, which begins with the following anchor — "Mawlana Hazir Imam (His Highness addressed by the Ismaili community) — has the inherent right and absolute and unfettered power and authority over and in respect of all religious and jamati matters of the Ismailis" (Aga Khan IV, 1986, p. 9). Furthermore, the Imam has the sole authority to "confer a constitution on the Jamat and amend or discontinue any such constitution or any provision thereof" (ibid.). Religious matters focus on the practice of the Ismaili 
tariqah (i.e. "path") and broadening the understanding of Ismailis in relation to other Muslim communities. The scope of jamati matters may include the functioning of the community vis-à-vis the council structure and the construction of Jamatkhanas (i.e., house of congregation). The Imam provides Ismailis with guidance in matters related to both spiritual and material issues. This includes reconciling issues of modernity with Islam, integration within a particular country context, and enhancing the overall quality of life in various parts of the world.

The Aga Khan has at times been compared to the pope of the Roman Catholic Church and at others times to a head of state. However, neither category is sufficient as will be demonstrated in this dissertation. It is the capacity to bring together the notions of Din (i.e., spiritual) and Dunya (i.e., material) that the position of the Aga Khan is best suited. The state-like qualities of the Imamat will be explored later in this dissertation, but a brief comparison between the authority of the Imam and that of the pope will be instructive. The papacy is described as "the office and jurisdiction" of the pope. ${ }^{3}$ The Holy See ${ }^{4}$ headed by the pope, is the entity that encompasses the authority and government of the Church and maintains diplomatic ties ${ }^{5}$. Vatican City State is a distinct entity of which the pope is the Sovereign ${ }^{6}$. The pope provides general guidance about material matters but the focus is on religious doctrine and moral issues. As such, engagement in for-profit enterprise is not an area of concentration. However, there are various levels of engagement in social provision under the pope's jurisdiction. The pope is elected by the College of Cardinals while the Imam's position is hereditary. The Imam

\footnotetext{
${ }^{3}$ See $<$ www.britannica.com/EBchecked/topic/441722/papacy $>$

${ }^{4}$ It is often referred to as the "Vatican" and resides in Vatican City State

${ }^{5}$ See $<$ http://www.britannica.com/EBchecked/topic/1060041/Holy-See $>$

${ }^{6}$ Founded in 1929 with the Lateran Pacts between the Holy See and Italy. $<$ http://www.vaticanstate.va $>$
} 
is the unfettered authority in the Ismaili community context, so any interpretation and directives stem directly from the Imam's position. In the Roman Catholic context, the doctrine of infallibility articulates that the pope "acting as supreme teacher and under certain conditions, cannot err when he teaches in matters of faith or morals". ${ }^{7}$ However, the pope is also supported by senior Clergy at the Vatican, who are involved in the study of religious doctrine, provide a consultative function and administer church affairs. The power dynamic between the Imam and the Ismaili community is unidirectional. There are aspects of decentralization at the Council level, but ultimately the strategic vision and direction for the community are decided at the Imamat level. In essence, the Imam as the guide/leader of the Ismaili community is the foci and the reason why it exists.

\section{Allegiance of Ismailis to the Imam}

The relationship of the Imam and the Ismaili community is premised on allegiance. His Highness notes,

Historically, Ismailis are united by a common allegiance to the living hereditary Imam of the time in the progeny of Islam's last and final Prophet Muhammad (may peace be upon him) through his daughter Fatima and her husband, Hazrat Ali, the Prophet's cousin and the first Shia Imam. In the Muslim ethical tradition, which links spirit and matter, the Imam not only leads in the interpretation of the faith, but also in the effort to improve the quality of life of his community, and of the wider societies within which it lives. (AKDN, 2007h)

However, His Highness has stressed that the allegiance Ismailis followers have to him does not negate the allegiance Ismaili citizens have to their individual countries. The concept of allegiance is one that would benefit from some unpacking. The MerriamWebster (2012) online dictionary defines allegiance as "(1) $a$ : the obligation of a feudal

\footnotetext{
${ }^{7}$ See $<$ http://www.britannica.com/EBchecked/topic/441822/papal-infallibility $>$
} 
vassal to his liege lord $b$ : the fidelity owed by a subject or citizen to a sovereign or government 2: devotion or loyalty to a person, group, or cause". The level of loyalty and commitment as well as being subordinate to, is one that can include a wide spectrum. Allegiance can range from passive engagement to one that ascribes a complete level of devotion, and in a religious context, this could entail ascribing an all-knowing quality to the Imamat level.

A subordinate position in relation to the Imam in both spiritual and material matters brings into question the ability for community members and the Ismaili leadership to challenge the authority of the Imam. Also, the capacity to implement completely autonomous programs or bring to the forefront failures may be difficult. However, one could argue that centralization, allegiance to the Imam, and his guidance in the areas of education, advancing the role of women and economic development has propelled the community to move more rapidly into modernity.

The way this dynamic plays out within the Ismaili community is not the focus of this dissertation. However, in order to understand the complexity of this relationship, it would be beneficial to explore potential tensions. For example, the Imam within the community is considered and mandated as being supreme in matters related both to spiritual and material aspects, and this may create a strong pull for seeking proximity to the Imam. How this individual interest may conflict with those of the community needs consideration. For example, prestige, status and community capital are connected to an individual's symbolic proximity to the Imam (i.e., service), and in some cases, there is recognition for voluntary service and financial contributions to the Imam, both in the community and AKDN context. This could in some instances create a 
compelling need to connect to the Imam rather than to focus on community needs and priorities. The need for connection may also, to some extent, reinforce a superior/subordinate relationship within the community structure and create barriers to progress. Also, to what extent does fear of losing status (i.e., appointments, committees) within the community come into play when deciding how to engage with the Imam?

The connection of the community and Imam revolves around the mandate of the Imam (i.e., providing guidance in religious matters, economic development, education etc.) and the service provided by the community to the Imam to implement programs. Service is focused on the functioning of the Jamatkhanas, presiding on the Council and as Board Chairs and Committee members (appointed by the Imam) as well as volunteering to implement the various programs and services. The organization of the Ismaili community and the implementation of programs is highly dependant on voluntary service $^{8}$, and it is considered to be direct service to the Imam. Again, there is a link made between the individual community member and the Imam above and beyond the community level. This link provides the impetus to serve the community beyond notions of social obligation and reciprocity.

The vision of having a unified group of followers that have the capacity to work toward common welfare objectives is another area of interest. The cohesiveness of the Ismaili community is not straightforward. The Ismaili community comprises individuals with different cultures, languages, and have different socio-economic levels. As well, there have been differences in terms of access to the Imam, engagement in advisory

${ }^{8}$ The work of Dr. Zahra Jamal may have shed some further light on voluntarism within the Ismaili community, but at the time of dissertation writing the forthcoming book by Jamal, Z. "Work No Words": Voluntarism and Piety among South Asian Ismaili Muslims was under book manuscript preparation and the $\mathrm{PhD}$ thesis, Harvard University (2008) it was based on was under "embargo". 
positions, holding positions of leadership within the community and in AKDN institutions, as well as the capacity for resource generation. This has been concentrated in a certain segment of Ismailis; namely, the Khoja Ismailis. As described by Steinberg (2011),

The diasporic and generally affluent Khoja community, its roots in western india, with colonial migrations to Africa and later migrations to Europe and North America, forms the Ismaili elite. They are at the helm of many of the imam's institutions. They constitute the inner circles of the imam's advisers. Their practice determines the standard and norm for other Ismailis. It is only recently that the imamat encouraged Khojas and nonKhojas to see each other as part of a single community [...]. (pp. 195-196)

What implications these differences have for the Ismaili community as a whole and for its capacity to engage as a cohesive group, especially in countries such as Canada where there is now a commingling of Ismailis from Khoja and Central Asian (predominately from Afghanistan) backgrounds is an important consideration. The internal community dynamic, sharing of resources and engagement in institutional structures is explored in the Canadian case study. However, this is an area that needs further research.

\section{Ismaili Imamat - The Office of the Imam}

The office of the Imamat functions on two levels, one that is directed to the Ismaili community focusing on its spiritual and material well-being, and the other functions in a state-like manner to engage with governments, international organizations, and civil society organizations to address issues of health, education, and economic development. The Aga Khan Development Network (AKDN) is the mechanism that the office of the Imamat uses to engage with government, international agencies and civil 
society organizations. I will discuss the AKDN's background, structure, and levels of engagement in the next chapter.

The mandate of the office of the Imam in contemporary history includes helping Ismailis keep a balance between the two aspects of Din and Dunya (i.e., spiritual and material) and guide his community (Ismaili followers) in these areas. As such, the quality of life of Ismailis is seen as an obligation of the Imam. The community level institutions of the Council and Boards are a reflection of the vision of the Imam with Ismailis engaged in implementation and resource generation.

In addition, His Highness has noted that the commitment to improvement in quality of life extends beyond the Ismaili community to encompass the societies in which Ismailis live (AKDN, 2007m). Capacity building both within the Ismaili community and the countries where Ismailis predominately live is central. One of the aims noted in the Ismaili Constitution is for the Council "to serve the needs of the Jamat to enable it to make an effective contribution to the development of the societies in which it lives" (Aga Khan IV, 1986, p. 14). For example, Aga Khan III started with modernizing the programs/structures that were limited to the Ismaili community, and now there is an interesting issue of balance, where the institutions of AKDN have moved well beyond the Ismaili community, and in some countries there are AKDN entities, but there is no Ismaili presence.

The office of the Imamat is not considered a temporal one. As such, Imams build on the foundation of previous Imams, and are expected to continue with future Imams. Thus, the Imam emphasizes long-term planning both for Jamat institutions and AKDN. 
Another area of engagement of the office of the Imamat is in fostering Islamic pluralism and understanding. The importance of pluralism and understanding is reinforced by the various public speeches made by His Highness, sponsoring architectural awards, promoting building and historic restorations, the creation of the Aga Khan Museum in Toronto and the Global Centre for Pluralism in Ottawa.

\section{Scope of the Imamat Mandate}

The need for institutions in East Africa during the time of Aga Khan III was a key priority for Ismailis and the Imam as there were limited options for health and education because of the segregated race based policies at the time. As well, it was important to be able to engage with the market, which was initially facilitated by kin and community relationships. Thereafter, cooperative societies introduced during the time of Aga Khan III, allowed for systematic borrowing of money, for Ismailis to begin small businesses and invest in housing. Later, the role of women in the community became a focus, as having only half the community engaged would not maximize the potential of the community as a whole. As well, the role of women in income generation and ensuring money is spent on the family in areas of health and education and in turn, improving quality of life at the family level was recognized. For example, in a message to the Ismaili Women's Association of Karachi in 1953 Aga Khan III stated:

No progressive thinker of to-day will challenge the claim that the social advancement and general well-being of communities are greatest where women are least debarred, by artificial barriers and narrow prejudice, from taking their full positions as citizens. (as cited in Aziz, 1997, p. 1295)

The focus on the role of women and their participation in communal and noncommunal institutions continues with the current Imam. For example, women are 
involved in the highest levels of leadership in the community institutions in Canada as well as more recently within the ranks of AKDN. However, cultural factors may play a role in opportunities for Ismaili women depending on where they live and the dominant framework of the role of women in society.

Other priority programs were initiated after the Golden Jubilee (celebration of fifty years of Imamat) of the Aga Khan IV, including quality of life programs, early childhood education and programs for the elderly. The initiation of these programs may reflect a need that is not being fulfilled within the context of the broader AKDN initiatives or government welfare systems.

The mandate of the Imamat level seems to be intertwined in an interesting mix of public (i.e., government, market, civil society engagement) and private (i.e., Ismaili community) dichotomy. It puts the Imamat level at the centre of serving many constituents because of the way its mandate is framed. His Highness is the spiritual leader of the Ismaili community, so to describe the work of the Imamat that goes beyond the Ismaili community as secular seems to be limited. His Highness has described the work of AKDN as being the "social conscience of Islam" as well as linking the work of AKDN to humanistic ideals and a sort of cosmopolitan ethic (AKDN, 2007k; AKDN, 2007f).

This overarching mandate at the Imamat level envisions an environment where there is a level of security and a strong capacity in the areas of health, education, and economic development in countries where Ismailis live. As well, there is an emphasis on encouraging an enabling environment that would facilitate opportunities for Ismailis and others to achieve a certain level of quality of life, economic well-being, security, and the opportunity to practice one's faith. 
An Imamat obligation for quality of life broadens the rationale for welfare and how it is produced. The engagement in countries where Ismailis do not currently live (e.g., Burkina Faso) is an interesting development, but one could argue that it creates the ground work for a level of stability for Ismailis to have more choices of where to live in the future. Global markets are changing, and opportunities for business in emerging markets is yet untapped. The survival of the Ismaili community is linked to being able to enhance their material prosperity and negotiate the new environments where they live. Although Ismaili interaction in some countries is not directly linked to AKDN programs, their mere presence and engagement with governments and civil society organizations may act as a buffer for the Ismaili community. In other cases, having an Imamat institutional presence may create a sense of security and a feeling of being connected to a community when individuals are part of a minority. As well, members of the Ismaili community have relied on the Imamat level and its institutions in cases of heightened instability. This has included the Imamat role in ensuring the safety of Ismailis during the Uganda crisis in the early 1970's and the role of the Ismaili Council in conjunction with Imamat agencies (i.e., FOCUS Canada) in facilitating the immigration of Ismailis beginning in the 1990's to Canada from Afghanistan.

How this grand mandate and the vision at the office of the Imamat level are understood and implemented will be explored in the case study chapters. The Imamat level is ultimately responsible for decisions regarding strategic direction of all the Ismaili Council's and AKDN worldwide. The differences at the country level and how the dual mandate and vision at the Imamat level is translated into practice will also be explored. 


\section{Engagement Strategies and Mechanisms to Fulfil Mandate}

The office of the Imam functions on multiple levels by directing the Ismaili community, engaging with government, international organizations and civil society organizations in areas of social, culture and economic development as well as in policy and idea generation. The Imamat level can engage based on multiple logics and takes on a quality that can be considered a hybrid of state, market and civil society. The capacity for broad scale engagement by the Imamat level reinforces the legitimacy of the office and in turn, allows for even more engagement at the international, regional, national, and local levels. The capacity to shift and engage on multiple fronts is similar to the Ismailis themselves. This has allowed for an identity that is not necessarily fixed but rather dynamic and adaptable depending on context. This capacity to adapt to their environment has, in a sense, made it possible for Ismailis to function in difficult contexts as a minority in fragile states. In addition, the Imamat level acts as a focal point for identity that goes beyond culture, language, and nationality. The link to the Imamat level transcends the usual way we perceive of culture or ethnicity. This fluidity highlights the point that in many cases understanding of "culture" is stuck rather than having the capacity to incorporate, evolve, and become something else.

There are areas of contradiction between the Imamat engagement at the community level and its engagement with the broader context (i.e., government, privatesector and civil society organizations). For example, how issues of transparency and accountability are envisaged is not the same within the community level and externally. When His Highness engages with leaders in various developing countries, the importance 
of transparency and accountability is at the forefront. However, within the Ismaili community context, it is not necessarily the case that transparency and accountability are observed at all levels. For example, although there is a mechanism for audit of resources collected at the community level, the Ismaili community does not have access to that information. The Grants and Review Board (engaged with Council but not part of the Council) is the audit arm and is accountable to the Imam rather than the community itself. Also, other resources, for example, religious dues, are the prerogative of the Imam; therefore, it is unconditional. As the office of the Imamat in some ways becomes more public and visible and articulates openness and transparency, an interesting juxtaposition is created between the public and private aspects of the office.

\section{Ismaili Governance and Institution Building}

\section{Ismaili Constitution}

The Ismaili Constitution serves to outline the authority of the Imam, the governance structure of the Ismailis as well as the aims and goals of the Council. The first so-called Constitution or "rules and regulations" for the Ismaili community in East Africa came into effect shortly after there was a challenge to the authority of Aga Khan III in a Bombay High Court, when the Imam was visiting Ismailis in East Africa in 1905 (Daftary, 1998, p. 200). However, Hirji (2011) points to other instances of rule books for Ismailis, for example, Bombay in 1901 and earlier unsuccessful attempts to develop laws for the Ismaili community during the time of Aga Khan I and II (pp. 147-148). Nonetheless, the rules and regulations developed in 1905 were a key turning point in establishing more of a centralized control over the affairs of the Ismaili community. 
The recognition of the authority of Aga Khan III by the British courts validated the seat of power of the Imamat and reinforced his authority and status within the Ismaili community.

Although the term Constitution is used to describe early iterations of the rules and regulations for the Ismaili community, Hirji (2011) notes that it was not until 1946 that the word Constitution appears in the title of the written "rules and regulations". Nonetheless, he acknowledges that the effect was similar to a Constitution. The first region in East Africa where the "rules and regulations" were applicable was in Zanzibar. The rules and regulations and later Constitution served as a systematic way of identifying the distinctiveness of the Ismaili community and outlining its governance structure (Daftary, 1998, p. 200). As well, the rules and regulations addressed the Imam's right to ownership of communal property (Nanji, 1974, p. 128). There were additional iterations of the "rules and regulations" as the Ismaili population grew beyond Zanzibar and more formalized structures were needed such as the Council administration (Nanji, 1974). Also, the rules and regulations outlined the procedures and consequences (i.e., excommunication) for challenging the fundamental authority of the Imam within the Ismaili Community (Nanji, 1974, p. 128). The formal rules and regulations served to bind the Ismaili community and removed any doubt about the authority of the Imam.

Aga Khan IV became Imam of the Nizari Ismaili community in 1957 and during his Imamat there have been two more formal Constitutions. One in 1962 expanded council responsibility to local affairs via economic committees, welfare societies, women's associations as well as youth associations (Nanji, 1974). The mechanism of the council and its link with the Imam is explained as follows: 
The various councils and organizations, seen against the background of the whole system, emerge as extensions of the Imam's authority and guidance, both of which, in a sense, mirror the community's vision of life. These extensions are coordinated to involve as many Ismailis as possible at varying levels of organization. Hence, though the main thrust comes from the Imam, it is, in actuality, the community by its involvement in the day-to-day workings of the system that keeps it functioning. (Nanji,1974, p. 131)

Furthermore, Nanji notes that the changes to the Constitution resulted after Aga Khan IV consulted with "Constitutional Committees" formed under his purview that provided input regarding changes after meeting with Ismailis in various African countries (ibid.). However, the ultimate decision regarding language and substance was the authority of the Imam. The most recent Constitution was promulgated in 1986. The document superseded any previous constitutions and served to consolidate and provide coherence to the Council system throughout the world, and it specified 15 territories with National councils (Aga Khan IV, 1986). This latest Constitution reinforces the authority of the Imam and his role as spiritual guide and the Imam's concern for quality of life of Ismailis as well as affirming the fundamental principles of Islam (Aga Khan IV, 1986). Ultimately, the Constitution serves to unify the Ismaili community worldwide and provides a vehicle for the Imam to have oversight of the community.

The Council system itself provided a mechanism for the modernization policies of Aga Khan III and IV to be implemented. The various Boards such as economic, education and health facilitated the building of schools, establishing cooperative organizations and health facilities (Nanji, 1974). Also, the appointments of Council Chairs and Board members are approved by the Imam, providing a level of control. In recent years, other regions of the world where contact with the Aga Khan was less accessible, such as Central Asia, are becoming more open. The inclusion of these regions 
in an appointed council structure as opposed to the traditional hereditary structure is underway.

The Ismaili Constitution in a sense is fashioned around the office of the Ismaili Imamat that has a state-like presence with the various branches of the Council and Boards reporting to the Imamat level. In a sense, the office of the Imam can be equated with a state-like entity without a country trying to manage its transnational community. The executive level can be aligned with the office of the Imamat itself, with the Presidents of the various National Councils reporting to the Department of Jamati Institutions (DJI) that, in turn, informs the office. The DJI is located in Aiglemont, and it plays a coordinating role for the various activities and programs of the Ismaili community's initiatives in the various countries. The legislative branch can be equated with the various boards of the National Council. The Grants and Review Board can be considered an auditor general type office; and finally, the Conciliation and Arbitration Board could be equated with a quasi-judicial body.

Although the focus of this dissertation is on the modern period of the Imamat and Ismailis, a brief glance at the historical roots of the community provides an understanding of the underpinnings for the state-like logic in the current office of the Imam.

The Ismaili Constitution (1986) itself notes that Ismaili Imams have previously ruled over territories in various parts of the world. There were two historical periods where the Ismaili Imamat established formal states attached to territory. The first was during the Fatimid period, the first Shia caliphate 297 A.H /909 A.D. in North Africa (Daftary, 1998, p. 1). However, after the death of Imam al-Mustansir, there was a split of Ismailis because of issues of succession of Imamat. Two branches resulted, namely, the 
Nizari and Mustalian. A state was founded by the Nizari branch in Persia concentrated in Alamut around the time of 488 A.H./1095 A.D. The state came to an end after defeat by the Mongols 654 A.H./1256 A.D. (Daftary, 1998, pp. 1-2). The current Aga Khan claims lineage to the Nizari Branch. After the $13^{\text {th }}$ century, there were no territorial based Ismaili states. However, Sir Sultan Mohammed Shah, Aga Khan III, mentions in his memoirs his attempt to secure a territorial state in India in the 1930's for Ismailis, albeit unsuccessfully (2005, p. 142). He attributed the desire for a territorial state to the Ismaili community's aspiration rather than his own.

Nonetheless, despite not having a state, this notion of a state-like logic persists with the current Aga Khan. It is exemplified by the number of protocol agreements that are in place with various countries, and the Imamat level is represented in those countries by individuals that in some cases have ambassadorial status. In addition, permanent embassy like entities such as the Delegation of the Ismaili Imamat in Canada, in the midst of other embassies in Ottawa, reinforces this state-like logic. This idea of not necessarily having a territorial space where individuals are linked but at the same time having the logic of a state is described by Kjellberg in Kaiser (1996):

the Ismailis do not have a country of their own anywhere in the world-- in some ways they are like the Jews before the creation of Israel. But wherever they are found, they tend to create a "state within a state," characterised by an elaborate structure and an efficient organisation, unless discouraged or prevented by a centralising government. (Kjellberg, 1967 as cited in Kaiser, 1996, p. 20)

More recently, Steinburg (2011) in theorizing an Ismaili globality argues:

Certainly in a world of nation-states the Ismaili formation embodies something anomalous and unique. Whether Ismaili transnationality, emerging as it does from a set of widely shared historical conditions, might potentially constitute a token of a more universal type, a harbinger of things to come, cannot yet be answered. Whether it fills the role 
formerly or normally filled by the state is a question whose answer varies from setting to setting. That it draws attention to a possibility for allegiance and membership external to the system of states is undeniable [...]. (p. 208)

Given the previous historical connections to state entities, the current formulation of the Ismaili Imamat may constitute a new imagining of what it entails to encompass a statelike logic.

\section{Governance}

The governance structure of the Ismaili community is hierarchical in nature, and it is centralized at the Imamat level. The structure consists of national, regional, and local Council and Boards. This allows for the Councils and Boards to take different contexts into account when determining the priorities and needs of the Jamat.

The Council system has been developed over time and has evolved to accommodate the various stages of Ismaili migration. The periods of focus in this dissertation include the initial migration of Ismailis from India to East Africa, Ismaili migration from East Africa to Canada in the 1960-1970's, and the migration of Ismailis from Afghanistan to Canada in the 1990's. The Council structure focuses on various aspects including health, education, economic development, social welfare (i.e., poverty alleviation) and more recently, the care for the elderly and early childhood education. A key rationale for the Council programs and services is to provide Ismailis with an infrastructure to address issues related to capacity building and foster self-reliance. This internal organization has contributed to the capacity for Ismailis to function and seek support in countries in which they live and acts as a potential stabilizing factor, should Ismailis choose to migrate to other parts of the world. As the level of government 
supported welfare differs in the various countries where Ismailis live, the Council and various Boards seek to provide a buffer for the Ismaili community.

There are different streams of funding within the Ismaili community. Religious dues are directed to the Imam who has unconditional authority as to the allocation of those funds (Daftary, 1998; Walji, 1974). A Jamati Development Fund is collected based on donations from community members for the various programs and services implemented by the Council and Boards. This would include services such as the social welfare fund, services for the elderly and supplemental services in the areas of economic development and education. Although the infrastructure of the various Councils and Boards are similar, the human resource capacity and financial resources available may vary. As well, issues of donor fatigue may come into play when there are multiple streams of financial obligation and requests (e.g., religious dues, donations to the Jamati Development Fund, and donations to AKDN). The funding for the administrative component of the Council including any full-time staff and the physical building is provided by the Imamat level.

The Chair and Board members are appointed every three years. These individuals volunteer their time and are usually professionals (both men and women) within the community. The structure and function of the Council and Boards are outlined in the Ismaili Constitution. It also provides guidelines for the objectives and aims for the Council.

How the Council is perceived by members of the community is something that needs more examination. For example, is it an open or closed system? Are there mechanisms in place for the community to be directly involved in decision making? 
Is there a gap in terms of Ismailis from different parts of the world and different practices and their capacity to access levels of support? Although the individuals interviewed for this dissertation held positions of leadership within the Council and other structures, some of these questions, and tensions did come to the forefront.

The potential for collaboration between the Councils and AKDN (i.e., incorporated Central and Apex Institutions) as stipulated in the Constitution is another area that will be explored in greater detail in the case studies. The AKDN will be examined in more detail in the next chapter. However, it is important to note that there are Apex institutions including the Aga Khan Foundation (AKF), the Aga Khan University (AKU), the Aga Khan Fund for Economic Development (AKFED) and the Aga Khan Trust for Culture (AKTC). There are also incorporated Central institutions which include the incorporated bodies of Aga Khan Education Service (AKES) and the Aga Khan Health Service (AKHS), Aga Khan Planning and Building Service (AKPBS) and the communal unincorporated bodies of the various Boards (i.e., Economic Planning, Education, Health, Housing, Social Welfare, Youth and Sports) (Aga Khan IV, 1986). As Aga Khan IV moved to streamline the Institutions, the Apex institutions and Central institutions of the AKES, AKHS, and AKPB became known together as the Aga Khan Development Network. As well, the AKDN was positioned as being non-denominational and focused on broader development goals.

However, because the precursors to the more formalized incorporated bodies of AKES and AKHS originally focused on the Jamat, there is an attempt to maintain a link with the Council. This takes the form of Jamati committees within the national service companies of Aga Khan Education Service and Aga Khan Health Service. However, as 
will be demonstrated in the Tanzania case study, there in an interesting dynamic that is evolving as the AKDN trajectory has shifted beyond the Ismaili community level. The target market for AKDN agencies in Tanzania is no longer the Ismaili community, and this brings to the forefront whether there is a need to have a complete separation of AKDN from the community and instead, focus on enhancing community level structures. In essence, is there a need for a parallel system that is designated for a so-called "priority" community? There may also be a need for a re-evaluation of the connection of the Ismaili community to the AKDN institutions. This could entail articulating that although the Ismaili community was instrumental in the initial phases of institution building, the individuals that are now being served have shifted, so there is no need to ensure Ismailis are still involved in the governance of AKDN. Fundamentally, the issue is that of ownership of institutions, and as was described earlier that does not reside at the Ismaili community level but rather, at the Imamat level. Although there are individual Ismailis working in various voluntary and paid positions including leadership within AKDN, it does not necessarily signify that the needs of the community are being addressed. This tension seems to exist because the current donors and so-called beneficiaries are no longer predominately from the Ismaili community, so there is to some extent, an air of trying not to be seen as prioritizing the Ismaili community. Also, there are still remnants of the sentiment that the Aga Khan institutions are exclusively for the Ismailis. Hence, there is a need to justify that this is not the case.

\section{Self-reliance and Independence}

The focus in the context of Ismaili community as well as AKDN is on selfreliance and independence. However, the implications this may have for individuals that 
are unable to engage fully in the market and are dependent on a donor driven system will be explored in the case study examples. It could be argued that the community as a whole, beyond what the Imamat level does (i.e., ensuring administrative costs are covered), is responsible for poverty alleviation, and overall community development. However, as will be explored in the case studies, the level of engagement of individual Ismailis runs the spectrum from those that may find a sense of belonging and an outlet to express service to the Imam at the community and AKDN level while others may compartmentalize the spiritual and material aspects of their lives, and for some there may be a level of detachment from the community itself.

\section{Regionalization}

The Councils are structured predominately on a country basis, but there is potential for regionalization. The Constitution notes the importance of working in "close collaboration with other Councils in different regions of the world" (Aga Khan IV, 1986, p. 14), and some countries with a small Ismaili presence may fall under the jurisdiction of another country in the region. In a sense, the Constitution serves to unite the Ismailis worldwide and inculcate a transnational connection. However, the push for regionalization seems to be more of an urgency at the AKDN level than for Councils.

However, given the allegiance to the Imam is not linked to a country per se, the potentiality for such collaboration exists. In addition, the engagement of the Imamat level in fora that brings to the forefront the importance of regional capacity may further reinforce a regional perspective within the community structures to foster long-term 
stability. The potential of sharing resources and best practices in comprehensive ways will be explored in the case study examples.

\section{Centralization and Decentralization of Engagement Structures}

The Ismailis to some extent have a hybrid community approach that is both centralized and decentralized. The power of strategic direction and vision is centralized with the implementation of programs and services being more decentralized. Even with aspects of decentralization, there is a hierarchy in place, and it is concentrated at the Council and Boards rather than the full engagement of the community itself. However, there are informal needs assessments conducted at the community level to help inform direction. At the leadership level, although the capacity to engage with the Imamat level and articulate a certain position or collaborate is available in theory, the willingness to do so is intertwined with the Imam having an unfettered authority over the community. This may lead to a level of hesitancy to fully engage with the Imamat level.

The Council structure itself is a mechanism that allows for a great degree of centralization at the Imamat level. The appointment of the Board Chairs, and members are overseen by the Imam and decisions are finalized at that level. In addition, the key strategic direction, policy directives and ultimate decisions regarding programs and services are approved at the Imamat level.

\section{Conclusion}

As described, the Imamat level holds a central position within the Ismaili community and in many ways plays an intermediary position in its connection to state, 
market, civil society organizations and the community level. To some degree AKDN is the mechanism that the Imamat utilizes to engage with the various sectors while the Ismaili Council structure is the mechanism that the Imamat uses to engage with the Ismaili community. In a sense, the office of the Imamat holds the "fourth position" as described by Fowler (2000). There have been compelling reasons throughout the evolution of the Ismaili community for not being confined by a particular sector logic. The idea of blurring the lines between sectors as described by Evers (2005) and Molina (2009) comes to life when considering the crucial points in the Ismaili background and history. However, the capacity to straddle multiple logics may create a dominance of a particular logic at a specific time and place. The AKDN background chapter and the two case studies will help further tease out these ideas.

The authority or legitimacy to engage in this "fourth position" is possible vis-à-vis the community level by having in place a doctrine of Imamat that places the Imam at the pinnacle. In addition, this authority was solidified via crucial court cases in the Ismaili historical context. The capacity for the Imamat level to engage with government and international organizations is rooted in the historical context of Imams having territory and later engaging as strategic intermediaries for the British, for instance. This capacity continues in a different form today, but it is recognizable in its broad scale national and international level engagement and in the formalized protocol agreements with various countries. Despite not having territorial basis, the Ismaili Imamat continues to be able to engage with state entities.

The current engagement and management of the Ismaili community on a transnational basis no longer make the confines of a particular state a necessity. 
This is similar to transnational policy networks and the capacity to engage with multiple scales, be they local, national, or regional. It opens the space where ideas about policy issues (i.e., welfare) can be fostered. The requirement of the Imamat level to take into consideration the transnational and regional needs of the Ismaili community provide the impetus to examine issues of welfare from a broader perspective. 


\section{CHAPTER 3: AGA KHAN DEVELOPMENT NETWORK (AKDN) BACKGROUND}

\section{Overview of AKDN}

As the scope of social and economic programs grew from those initiated by Aga Khan III (1885-1957), a more comprehensive and integrated approach was envisaged by Aga Khan IV (1957-present) to address issues facing developing countries. The consolidation of the Apex and incorporated Central institutions under the umbrella of AKDN started taking shape after the 1986 Constitution.

Although the evolution of what is now AKDN started with the Ismaili community and there is still a connection via volunteers, financial resources, and individual Ismailis serving in governance, management, and other positions, there has been a shift. Even when Ismailis were the focus of programs and services, one could argue that the Imamat level was the strategic visionary of welfare production rather than the Ismaili community itself. This is because the strategic and ultimate decision-making takes place at the Imamat level for both the Ismaili Council and AKDN.

Describing the AKDN is a difficult task. As suggested in the theoretical chapter, there is a need to envisage the possibility of a "fourth position" (Fowler, 2000) directing the institutions. The office of the Imamat holds that space which is not confined to a particular logic, and AKDN is an extension of that office, trying to tap into, and affect multiple sectors simultaneously. As described by Aga Khan IV, " the Network is a model in its own right. We work with international financial institutions, government, 
development agencies, the private sector, both local and international, for-profit and notfor-profit and civil society groups.” (Aga Khan IV, 2012, p. 9). Ruthven (2011) in an overview of AKDN, notes:

AKDN eludes familiar definitions based on normal organizational categories. It is neither a non-government organization (NGO) concerned with international development or a faith-based charity [...]. In several countries its representatives enjoy diplomatic status and have close relationships with government, allowing them to engage in policy discussion at the highest levels. However, they are not state actors and operate within a tradition of strict political neutrality. While the Network includes profit-making enterprises [...], it does not fit the model of the business conglomerate that claims to be committed to 'good corporate citizenship'; the ratio of profit and non-profit sectors in the Network, [...], is much more evenly balanced. (2011, p. 190)

The Aga Khan Development Network (AKDN) is now active in over thirty countries $^{9}$ in both the developed and developing world. The AKDN is described as a group of private, international, non-denominational agencies with the aim of building institutions and programs that can address social, economic and cultural issues from a long-a term perspective in specific regions of the developing world (AKDN, 2007). The scope of AKDN now spans more than 140 separate entities and employs 58,000 individuals as well as relies on 20,000 volunteers (Ruthven, 2011, p. 189).

After providing an overview of the organizational structure of the AKDN, I will highlight several areas that need further exploration. These include:the engagement of the Ismaili community with $\mathrm{AKDN}$ and the shift in focus from the community level to the broader context; the impact of having a spiritual leader grounded in the ethics of Islam engaging in broader initiatives; the rationale for the for-profit segments of the Network as

\footnotetext{
${ }^{9}$ Countries include Afghanistan, Bangladesh, Bosnia-Herzegovina, Burkina Faso, Canada, Congo (DRC), Côte d'Ivoire, Egypt, India, Kazakhstan, Kenya, Kyrgyz Republic, Madagascar, Mali, Mozambique, Portugal, Pakistan, Switzerland, Syria, Tajikistan, Uganda, United Kingdom and the USA
} 
well as the relationship to the not-for-profit components of the Network, and finally the evolution of AKDN's institutions and capacity to engage with a wide spectrum of stakeholders including government, private-sector, international organizations, donors, and civil society organizations.

The AKDN is hierarchically structured, in that it is directly linked to the office of the Ismaili Imamat (see Appendix).

Table 3-1 Summary of Key AKDN and Non-AKDN entities

\begin{tabular}{|c|l|}
\hline Economic Development & \\
\hline $\begin{array}{c}\text { Aga Khan Fund for Economic } \\
\text { Development (AKFED) }\end{array}$ & $\begin{array}{l}\text { The coordinating body for the for-profit } \\
\text { components of AKDN. }\end{array}$ \\
\hline Financial Services & $\begin{array}{l}\text { Includes banks, insurance services, } \\
\text { property ownership and management. }\end{array}$ \\
\hline Media Services & $\begin{array}{l}\text { National newspapers, radio and television } \\
\text { stations. }\end{array}$ \\
\hline Tourism Promotion Services (TPS) & $\begin{array}{l}\text { Construction, rehabilitation and } \\
\text { management of hotels and lodges. }\end{array}$ \\
\hline Industrial Promotion Services (IPS) & $\begin{array}{l}\text { Investment and management of } \\
\text { infrastructure, power generation and } \\
\text { telecommunication projects. }\end{array}$ \\
\hline Aviation Services & $\begin{array}{l}\text { Improvement of aviation infrastructure } \\
\text { (i.e., investment, management and } \\
\text { training). AKFED has investments in } \\
\text { airlines in Burkina Faso, Mali and Uganda. }\end{array}$ \\
\hline Social Development & $\begin{array}{l}\text { Microfinance and micro-insurance } \\
\text { institutions and integrated development } \\
\text { initiatives. }\end{array}$ \\
\hline Aga Khan Agency for Microfinance \\
(AKAM) & $\begin{array}{l}\text { Programs focus on poor and vulnerable } \\
\text { populations. The areas of concentration } \\
\text { include health, education, rural } \\
\text { development, environment and enhancing } \\
\text { civil society institutions. Also, it engages in } \\
\text { policy issues and raising awareness of } \\
\text { development issues. }\end{array}$ \\
\hline Aga Khan Foundation (AKF) & $\begin{array}{l}\text { Includes a Medical College, School of } \\
\text { Nursing, Educational development, } \\
\text { teaching Hospitals, post-graduate medical } \\
\text { programs, advanced nursing programs, and } \\
\text { the Institute for the Study of Muslim }\end{array}$ \\
\hline Aga Khan University (AKU)
\end{tabular}




\begin{tabular}{|c|c|}
\hline & $\begin{array}{l}\text { Civilisations (ISMC). A Faculty of Arts } \\
\text { and Science in Karachi and a regional } \\
\text { University in Tanzania are in planning and } \\
\text { development stages. }\end{array}$ \\
\hline University of Central Asia (UCA) & $\begin{array}{l}\text { Founded by the governments of } \\
\text { Kazakhstan, the Kyrgyz Republic and } \\
\text { Tajikistan, and His Highness. The focus is } \\
\text { on social and economic issues facing } \\
\text { mountain societies. }\end{array}$ \\
\hline Aga Khan Education Services (AKES) & $\begin{array}{l}\text { Includes pre-school, primary and secondary } \\
\text { schools. }\end{array}$ \\
\hline Aga Khan Health Services (AKHS) & $\begin{array}{l}\text { Private not-for-profit health services (i.e., } \\
\text { health clinics and hospitals). }\end{array}$ \\
\hline $\begin{array}{l}\text { Aga Khan Planning and Building Services } \\
\text { (AKPBS) }\end{array}$ & $\begin{array}{l}\text { Focuses on housing design \& construction, } \\
\text { sanitation, and natural disaster mitigation } \\
\text { (e.g., earthquakes, floods). }\end{array}$ \\
\hline \multicolumn{2}{|l|}{ Culture } \\
\hline \multicolumn{2}{|l|}{ Aga Khan Trust for Culture } \\
\hline Aga Khan Award for Architecture & $\begin{array}{l}\text { Award for excellence in architecture, } \\
\text { planning and historic preservation in } \\
\text { countries with a significant Muslim } \\
\text { population. }\end{array}$ \\
\hline Historic Cities Support Programme & $\begin{array}{l}\text { Building and conservation of public spaces } \\
\text { in Muslim societies. }\end{array}$ \\
\hline $\begin{array}{l}\text { Aga Khan Program for Islamic } \\
\text { Architecture (Harvard and MIT) }\end{array}$ & $\begin{array}{l}\text { The study and application of Islamic art, } \\
\text { architecture and urban planning. }\end{array}$ \\
\hline Music Initiative in Central Asia & $\begin{array}{l}\text { Focus is on retention, and dissemination of } \\
\text { musical traditions. }\end{array}$ \\
\hline Museum \& Exhibitions & Museum and exhibit coordination. \\
\hline \multicolumn{2}{|l|}{ Non-AKDN Entities } \\
\hline Global Centre for Pluralism (GCP) & $\begin{array}{l}\text { Initiative of the Aga Khan and founding } \\
\text { partner the Government of Canada. The } \\
\text { focus is on research and dissemination of } \\
\text { information related to plural societies } \\
\text { around the world. }\end{array}$ \\
\hline Delegation of the Ismaili Imamat & $\begin{array}{l}\text { A space for dialogue and engagement on } \\
\text { issues of relevance to overall development. }\end{array}$ \\
\hline FOCUS Humanitarian Assistance & Emergency relief and relocation services. \\
\hline Institute for Ismaili Studies (IIS) & $\begin{array}{l}\text { Study of Shi'ism with a focus on Ismaili } \\
\text { history and translation of historical texts. }\end{array}$ \\
\hline
\end{tabular}


A brief overview of some key economic and social entities of AKDN with an emphasis on East Africa and Canada is highlighted below. More detailed analysis of the relevant entities is provided in the case study chapters.

\section{Aga Khan Fund for Economic Development (AKFED)}

The Aga Khan Fund for Economic Development (AKFED) is the for-profit component of AKDN and operates upwards of ninety separate project companies and employs approximately 30,000 people in East Africa, West Africa, South Asia and Central Asia. The revenues are estimated at US $\$ 1.5$ billion (AKDN, 2007, p. 13). AKFED was formed in 1984, building on the institutions established by Aga Khan III.

The financial services institutions were initially conceived as cooperative societies but later transitioned, under the present Aga Khan, to more formalized banks, general and life insurance companies. For example, the precursors of the current Diamond Trust Bank started in the 1930's in Kenya focusing on housing and small businesses for the Ismaili community. The more formalized entity Diamond Jubilee Investment Trust Company Limited (DJIT) was established in the jubilee year (1946) of Aga Khan III. There were branches in Tanzania, Uganda and Kenya. It transitioned to a commercial bank in Tanzania in 1997. The insurance component includes the Jubilee Insurance Group operating in Kenya, Tanzania, and Uganda offering general, life and medical insurance. As well, AKFED has investments in the financial sector in other countries $^{10}$ that were acquired or established at various times since 1941 (AKDN, 2007, p. 14). The tourism sector includes Serena Hotels, which are located in various countries of

10 Countries include Bangladesh, India, Kyrgyzstan, and Pakistan. 
Africa and Asia ${ }^{11}$. AKFED is also a shareholder in various media services in Kenya, Uganda, and Tanzania. The media services include newspapers, TV, radio as well as Nation Marketing and Publishing Limited and Nation Carriers division. The Aviation Services include various investments in airlines and the aviation services sector (i.e., investment, management and training) in East and West Africa (AKDN, 2007).

Large-scale projects and encouraging private enterprise has been the focus of Industrial Promotion Services (IPS) since 1963 in various countries of sub-Saharan Africa and South Asia (AKDN, 2007, p. 17). These include various projects in food and agro processing and infrastructure. Some key infrastructure projects include electricity generation and development in Tajikistan, a hydro project in Uganda as well as telecommunications services in Afghanistan and Tajikistan. The underpinning of AKFED is to take a lead role in high-risk investment ventures in developing countries of interest and act as a "magnet" for others to follow (Ruthven, 2011, p. 211).

\section{Social Development}

The Aga Khan Foundation was established in Switzerland in 1967. There are currently branches and affiliates in Central and South Asia, the Middle East, Sub-Saharan Africa, Europe, and North America. The Foundation is engaged in program delivery, fundraising and providing grants as well as research and policy dialogue to share its experience and knowledge (AKDN, 2007, p. 23). AKF stresses a multi-dimensional and long-term approach to development; the areas of concentration include rural development, health, education, civil society, and the environment. AKF is engaged in building partnerships among various stakeholders including the community and the state. In some

${ }^{11}$ Countries include Afghanistan, Kenya, Mozambique, Rwanda, Tajikistan, and Tanzania 
countries the Foundation is involved in policy promotion and in supporting reform of health systems (AKF, 2008, p. 32).

The formal Aga Khan Education Services (AKES) was established in 1986. However, the focus on the importance of learning is traced to historical Muslim traditions that date back over a thousand years (AKES, 2003). The Ismaili community education initiatives go back to the early 1900's in East Africa and South Asia, beginning at the community level and then later under the direction of the Imam. In 1905 the learning centres were structured under local and provincial Education Boards of the Ismaili community. In 1970 the idea of the "service company" was envisaged where the community structures started becoming more formalized (ibid.). Currently, AKES encompasses a school system with over 300 schools $^{12}$ from pre-primary to higher secondary levels, including schools of excellence (i.e., Aga Khan Academies) (AKES, 2003). There are some links between Education Boards (part of the Council system) in Europe and North America and AKES that foster information exchange on issues such as early childhood education, parental involvement, and career counselling while there is a Jamati committee as part of the AKES structure in developing countries such as Tanzania.

The current governance structure of AKES incorporates international, national, and local elements. The Social Welfare Department (SWD), located in France has overall responsibility for developing, managing, and coordinating the various education initiatives. The activities of the various service companies are coordinated by SWD through strategic plans and budgets. In addition, SWD provides technical assistance to individual country programs (AKDN, 2007a). The national service companies are said to

${ }^{12}$ Countries include Pakistan, India, Bangladesh, Kenya, Kyrgyz Republic, Uganda, Tanzania, and Tajikistan 
plan, organize, and finance the education services. However, the actual level of decentralization will be explored in more detail in the Tanzania case study example. The national service companies are registered as not-for-profit entities in the various countries of operation. Aga Khan Education Services S.A., the not-for-profit company in Geneva, Switzerland is the sponsoring company and appoints the chairperson as well as directors of the boards as necessary (ibid.). The fact that AKES is based on a volunteer governance structure as well as being rooted in the community is highlighted as a strength (ibid.). In addition, the importance of being cost-effective and efficient is stressed. The funding for AKES in various countries consists of local fees, community support, international donors and contributions from the Aga Khan.

The Aga Khan Health Service (AKHS) today includes a variety of private not-forprofit hospitals and clinics that started off serving the needs of the Ismaili community. Currently, there are approximately 200 community health programs, health facilities including hospitals in Central and South Asia as well as East Africa (AKDN, 2007b). In addition, AKHS provides technical assistance in health service delivery to governments. As with AKES, the SWD coordinates the activities of the individual service companies. AKHS is also based on the service company model. The AKDN literature states that the planning and management of the service company is decentralized and rests with the board appointed CEO. The funding for services, facilities and programs include user fees, community support, international donors and contributions form the Aga Khan (ibid.). An "entrepreneurial approach" is emphasized in all operations of AKHS national service companies (ibid.). For example, even in the area of community health programs and 
services there are strategies in place to achieve self-sufficiency, which can have a timeframe of 15-20 years (ibid.).

The Aga Khan University (AKU) was the first private international university chartered in Pakistan in 1983. The School of Nursing began its programs in 1980 and in 2001 initiated Advanced Nursing Studies programs in Kenya, Uganda and Tanzania ${ }^{13}$ (AKDN, 2007). The Aga Khan University Hospital in Karachi established in 1985 is the primary teaching site for the school of nursing and medical college. As of 2004, postgraduate programs were offered in Kenya and Tanzania at the Aga Khan Hospital in Nairobi and Aga Khan Hospital, Dar es Salaam (ibid.). In 2005, the Aga Khan Hospital in Nairobi, initially established in 1958 and operating under the management of Aga Khan Health Services, became a part of the Aga Khan University structure. The Institute for Educational Development was established in 1993 in Karachi. It focuses on improving educational standards in primary and secondary schools as well as school management and leadership. The Institute is involved in policy studies and dialogue with government regarding the education sector. Another Institute for Educational Development located in Tanzania, with a regional focus, was established in 2007. The Institute for the Study of Muslim Civilisations (ISMC) located in the United Kingdom established in 2002 is also part of the University. A Faculty of Arts and Science is in development phases and is to be located on a separate campus outside Karachi. A regional Aga Khan University for East Africa located in Arusha, Tanzania is also in the planning and development stages.

\footnotetext{
${ }^{13}$ The University nursing program also has a presence in Afghanistan, Egypt and Syria.
} 
The University of Central Asia (UCA) was founded in 2000 as a joint endeavour by His Highness and the governments of Kazakhstan, the Kyrgyz Republic and Tajikistan. The international treaty and charter for the University were signed by the Aga Khan and the Presidents of the relevant countries, and it is registered with the United Nations (AKDN, 2007, p. 47). UCA is in various stages of implementation and development.

The micro-finance products and services of AKDN are overseen by the Aga Khan Agency for Micro-finance (AKAM). Micro-finance initiatives have been a part of AKDN programs for over 25 years and were previously managed in partnership by AKF, AKFED, and AKTC. The products and services under micro-finance include income generation loans as well as loans to finance health care, education, and housing. In addition, more recent offerings include savings, micro-insurance, micro-leasing and money transfer services (AKDN, 2007, pp. 37-39).

\section{AKDN Affiliates and Other Organizations}

FOCUS Humanitarian Assistance is an affiliate of AKDN and is an international relief agency developed in 1994. It is described as an initiative of the Ismaili community under the direction of His Highness the Aga Khan IV (Focus, 2009). It has offices in Central and South Asia Europe as well as North America. It provides various forms of emergency assistance to communities after natural disasters, crisis situations, and assistance with issues of resettlement. Also, FOCUS is engaged with various disaster risk reduction programs such as assisting in the building of seismically resistant homes (Focus, 2009). 
The Institute of Ismaili Studies (IIS) located in the United Kingdom, was founded in 1977 by the Aga Khan with an emphasis on Shi'ism, particularly on Ismaili history and translation of historical texts. ${ }^{14}$

The Global Centre for Pluralism is an initiative of the Ismaili Imamat in partnership with the Government of Canada that seeks to focus on research and dissemination of information related to plural societies around the world. The Delegation of the Ismaili Imamat located in Ottawa is described as an endeavour to help build relationships and provide a space for "quiet diplomacy" informed by the Imamat's outlook (AKDN, 2007h).

\section{AKDN funding for programs}

According to AKDN brochures (AKDN, 2007), the main sources of funding for development activities for AKDN include national governments, multilateral institutions, and private sector partners. The AKFED entities acquire funding through similar means as other private enterprise including banks and international lending organizations (interview 1). As well, the importance of the Aga Khan in making funds available for projects in countries that others may be apprehensive about (i.e., fragile environments, long time frame for return on investment) was seen as important (interview 1). It was pointed out that it is difficult to garner financial support for programs and services that do not already exist (ibid.). It is noted that AKFED reinvests all surplus in further development projects including social and cultural components (AKDN, 2007g) The funding for the social segments of AKDN is a combination of country donor agencies (e.g., CIDA, USAID, European Commission etc.), fundraising revenues of AKF's in

${ }^{14}$ For further information regarding the Institute of Ismaili Studies see $<$ http://www.iis.ac.uk> 
developed countries (i.e., Canada, US and the UK), government funding, and user fees (interview 1). In addition, the Aga Khan provides ongoing funding for administration, core program activities as well as new program and country activities. Although the core Ismaili community is no longer the only source of financial support, individuals within the Ismaili community continue to provide volunteer time, professional expertise as well as financial resources. The sources of funding are examined further in the case study chapters.

\section{Community v. Broader Scale}

Initially, the AKDN appears to be a community organization because of its connection to the Ismaili community, but on further investigation it is a more complicated relationship. The precursors to AKDN that started during the time of Aga Khan III were closely linked to the needs of the Ismaili community as many relied on the services in sectors such as health, education, and financial cooperatives. The impetus for services in the Ismaili community addressed issues of access, low income, and consolidating resources. In East Africa, for example, Ruthven (2011) notes that till the 1930's the financing for schools came exclusively from the Ismaili community with grants from the Aga Khan and after changes to colonial policies, schools opened up to broader segments of the population with grant-in-aid received from colonial powers. Although AKDN has grown in its scope, the literature still notes, "the fulcrum of the Network's activities, however, remains the Ismaili Community - its traditions of volunteer service, selfreliance, generosity and the leadership of the hereditary Imam” (AKDN, 2007, p. 5). However, it is important to explore how the Ismaili community fits in with the broader 
mandate of the AKDN. Currently, the AKDN is evolving to move into areas that are no longer directly connected with the Ismaili community, i.e., media, airlines, tourism and large-scale infrastructure projects. Also, the focus of the non-for-profit segments (e.g., AKES, AKHS) is on surplus generation and self-sufficiency, so finding new markets for services outside the Ismaili community is essential.

This shift from the Ismaili community to the broader context is described by a senior member of AKF in Geneva and a member of the overall AKDN committee as follows:

If you look at the key social development institutions which I would regard as AKHS and AKES, you go back to His Highness's predecessor and the early years of His Highness's time as Imam. Those institutions were primarily serving Ismaili communities $[\ldots]$. They were not generally conceived of as $[\ldots]$ open to the public. We have come a long way very deliberately over the last 50 years away from that, and I think it's really a reflection of the political evolution of the world and decolonization [...]. So there was a movement away from, for good practical and political reasons, concentrating on just community matters and trying to make these institutions not only serve broader populations, but be models [...]. The only institutions $[\ldots]$ that are only open to Ismailis are those that are run by the various Council Boards, and the other exception for some programs $[\ldots]$ of IIS which is not part of the AKDN. The rest of us are all nondenominational in terms of our legal status, the beneficiaries we serve, and our employment practices. [...]. (interview 1)

The strategic vision of the Imamat level and the implementation capacity of a loyal base is what has made the progression and scope of AKDN what it is today. In essence, the origins and existence of AKDN are rooted in the Ismaili community. However, as AKDN continues to evolve, it is becoming more of a "force-field" that is being pulled in many directions and is no longer confined to the initial religious community. Also, the growth of AKDN and the speed of its trajectory necessitates 
engaging in various partnerships and relationships with government and the private sector entities to help facilitate venturing into new areas of interest.

This can create a push and pull dynamic with the core Ismaili community, for example, members of the Ismaili community sit on Boards and are in positions of leadership within the AKDN organization and volunteer in various capacities. However, at some point can it become a hindrance to try and maintain an Ismaili community link when $\mathrm{AKDN}$ is positioned to address broader developmental goals?

As the growth of AKDN and the corresponding focus of the Imamat level on the broader context continues, the potential impact on Council programs and services needs closer examination. As discussed, there is a link between the Council and the Jamati committees of AKHS and AKES, but the robustness of this link needs exploration. The differences in capacity from a voluntary and financial perspective of the Council versus AKDN and how that is managed will be discussed in the case studies.

\section{Authority of His Highness the Aga Khan}

The role of His Highness vis-à-vis AKDN is important to describe. In a sense, he is AKDN. As with the community level, the ultimate decision-making and vision of the Network rests at the Imamat level. As discussed, the Imam is seen as a living guide, and he has the responsibility for interpretation of the Quran, security, quality of life, and spiritual well-being of the Ismaili community. Given the role allegiance plays in the relationship between the Aga Khan and his community and the underpinning of service to the Imam, the gravitation for individual Ismailis to be involved in the AKDN by seeing it as an Imamat institution is not difficult. The AKDN is described not as a personal venture 
of the Aga Khan though the name Aga Khan is at the forefront. Rather, it is described as an extension of the office of the Imam to fulfill his mandate as Imam.

Volunteers from the Ismaili community continue to play an integral part of AKDN as a mechanism to sustain the "para-companies model". For example, a recent initiative of the Time and Knowledge Nazrana (TKN) within the Ismaili community looks at how professionals within the community can be of service to AKDN and Council. The idea of self-sufficiency within a non-profit model will be discussed in the social versus economic section. AKDN is also branching out to the broader context for volunteer assistance and financial support.

As explained by a senior member of AKF in Geneva, there were several areas where individuals from the Ismaili community were thought to make a significant contribution to the overall work of AKDN. Volunteers for the AKDN governing bodies were said to be predominately individuals from the Ismaili community. Individual Ismailis were also seen as an important resource, in countries where AKDN operates, to draw on to provide in-country information regarding the status of the various projects. As well, the volunteer service provided in the hospitals and schools was seen as critical (interview 1).

His Highness has noted that AKDN and its focus on development comes not from a connection to philanthropy or entrepreneurship, but rather the institutional responsibility that emanates from the mandate of the office of the Imam to ensure the security, quality of life and the spiritual well-being of Ismailis as well as to enhance the capacity of societies where Ismailis live (AKDN, 20071). As such, the Imamat level is the intermediary space where the mandate for the Ismaili community and the broader based 
development efforts of AKDN rests. In this context, there is the potential for tensions between community based and broader based initiatives. The overall plan and mandate rests at the Imamat level with others within AKDN and the Council being privy to a particular snippet of the mandate and engaging based on their understanding of the logic of the organization. There were examples of individuals expressing the dual mandate of the Imam as the basis for the rationale of the programs and services of AKDN. For example, members of the leadership in AKFC and an AKF interviewee in Tanzania expressed an articulation of the Imamat role as one that is not exclusive to the Ismaili community, but one that has a responsibility to also be involved in overall issues of human development (interview 2 , interview $3 \&$ interview 28). This responsibility was seen to emanate from the historical traditions of the Imamat, and the demands placed on Muslim leaders to foster both spiritual and material well-being (interview 2, interview 3 $\&$ interview 28). Thus, the ethics and the social conscience of Islam are seen as the underpinning for the non-denominational work of the Network (interview 2).

Table 3-2 Key Coordination Mechanisms for the 'Office of the Imam'

\begin{tabular}{|l|l|}
\hline AKDN Committee & $\begin{array}{l}\text { Chaired by His Highness (HH). It is the } \\
\text { coordinating body for all AKDN } \\
\text { entities (economic, social and culture } \\
\text { entities). }\end{array}$ \\
\hline AKFED & $\begin{array}{l}\text { Coordinating body for AKDN profit- } \\
\text { making entities. Aga Khan's brother } \\
\text { Prince Amyn is Chairman of its } \\
\text { executive committee. Aga Khan's son } \\
\text { Prince Rahim is an executive director. }\end{array}$ \\
\hline $\begin{array}{l}\text { Social Welfare Department (SWD) in } \\
\text { Aiglemont }\end{array}$ & $\begin{array}{l}\text { Headed by Aga Khan's daughter } \\
\text { Princess Zahra. SWD coordinates the } \\
\text { national service companies (i.e., AKES, } \\
\text { AKHS). SWD has financial and } \\
\text { technical oversight. }\end{array}$ \\
\hline
\end{tabular}




\begin{tabular}{|l|l|}
\hline AKF (Geneva, Switzerland) & $\begin{array}{l}\text { AKF is part of the overall AKDN, but it } \\
\text { also has a separate AKF coordinating } \\
\text { body in Geneva. HH heads that Board, } \\
\text { and Prince Amyn is Director of AKF. }\end{array}$ \\
\hline $\begin{array}{l}\text { Aga Khan Agency Microfinance } \\
\text { AKAM) }\end{array}$ & $\begin{array}{l}\text { Coordinated from Geneva, its focus is } \\
\text { the overall micro-finance and micro- } \\
\text { insurance services. HH is the Chairman } \\
\text { of the Board. }\end{array}$ \\
\hline Aga Khan Trust for Culture (AKTC) & $\begin{array}{l}\text { Coordinates the cultural components of } \\
\text { AKDN. Prince Amyn is a Director. }\end{array}$ \\
\hline Department of Jamati Institutions (DJI) & $\begin{array}{l}\text { Coordinating body for Ismaili } \\
\text { Community Institutions (i.e. the non- } \\
\text { incorporated Central Institutions, e.g., } \\
\text { the Education Board, Economic and } \\
\text { Planning Board etc.) }\end{array}$ \\
\hline Other Entities & $\begin{array}{l}\text { HH, Princess Zahra and representatives } \\
\text { from AKTC and AKFC are on the GCP } \\
\text { Board. }\end{array}$ \\
\hline Global Centre for Pluralism (GCP) & $\begin{array}{l}\text { Imam's representation in Canada. } \\
\text { AKFC plays a facilitative role for the } \\
\text { DII and has its offices in the building. }\end{array}$ \\
\hline Delegation for the Ismaili Imamat (DII)
\end{tabular}

\section{Din and Dunya - The Balance between Spiritual and Material}

The role of faith-based organizations in development has in recent years become an area of growing interest. According to Clarke (2007), development is becoming defined in broader terms that encompass material and non-material aspects. Clarke states:

In contrast to the government-to-government paradigm of old, a new paradigm acknowledges the importance of multi-stakeholder partnerships, of including the private sector and civil society in development policy and of multiple tiers of partnerships and networks from local to global. In this context faith communities and FBOs are important actors, using the idioms of spiritual belief to provide practical support to the poor and to mobilise the popular moral energy needed to effect political change. (p. 90) 
However, within this context Clarke (2007) argues that donors such as DFID (the focus of his study) need to change conceptually and operationally to take into account the role of faith in development and consider challenges of engagement and funding of faithbased organizations. He writes:

Conceptually it must revise its secular and technocratic vision of development, $[\ldots]$ and explore practical overlaps between the previously separate worlds of faith and development. Operationally it must develop a more coherent corporate position on faith and development, promote faith literacy among staff, adjust its funding modalities to better accommodate FBOs, and diversify its engagement with FBOs beyond the mainstream Christian churches, while working to build their capacity and their inclusion in key development partnerships. (p. 91)

An interesting issue that will be explored in this dissertation is how an organization such as AKDN conceptualizes and interacts with its environment given its founder is a Muslim spiritual leader. Although the focus is on the non-denominational aspects of AKDN, there is a pull to address the broader role of faith-based (or faith-inspired) organizations in overall development. For example, Clarke (2007) notes that in 1998 James Wolfensohn (then President World Bank), Lord George Carey (then Archbishop of Canterbury) and the Aga Khan established an independent think tank (World Faiths Development Dialogue - WFDD) to focus research on the intersection of faith and development, with the goal of "building bridges" between donor and faith-based communities. However, an attempt to increase the profile of the "Directorate on Faith" (later renamed "Development Dialogue on Ethics and Values") within the Bank itself was not successful. This according to Clarke led the Aga Khan to withdraw support from the think tank (pp. 8182). The think tank continues, although the World Bank's website notes it was established in 2000 by Wolfensohn and Lord Carey and that the World Bank and WFDD signed a Memorandum of Understanding in May 2002. 
The capacity of the Imamat to maintain that intermediary space between Din and Dunya will be explored in more detail in this dissertation. However, it is important to point out that there is a range of organizations that fall on a spectrum of faith-based organizations and how they approach their role in the broader context of social provision. For example, the Mennonite Central Committee (MCC) ${ }^{15}$ clearly articulates the link of their work to faith. The purpose and vision of the organization states:

Mennonite Central Committee (MCC), a worldwide ministry of Anabaptist churches, shares God's love and compassion for all in the name of Christ by responding to basic human needs and working for peace and justice. MCC envisions communities worldwide in right relationship with God, one another and creation. (Mennonite Central Committee Canada, n.d.)

Organizations such as Unitarian Universalist Service Committee link their mandate to the Universal Declaration of Human Rights. The focus is placed on human rights and social justice issues.

Leurs, Tumanini-Mungu and Mvungi (2011) provide a first step in mapping the engagement of faith-based organizations in Tanzania. However, they note the difficulty in obtaining data regarding the various faith-based organizations and as such the study is an overview rather than a comprehensive analysis. Nonetheless, it highlights the need to understand the full spectrum of entities involved in development.

As will be discussed in this dissertation the importance of understanding the space for hybrid logics may also be informative in future research focused on understanding the full range of actors within the faith based-faith inspired continuum. As well, how donors

\footnotetext{
${ }^{15}$ MCC considers itself a relief and development service agency. It was founded in 1920 and is a joint initiative of Mennonite and Brethren in Christ Churches in Canada and the United States.
} 
and governments partner and fund the spectrum of faith-based organizations needs more evaluation and study.

Aga Khan IV describes why he is involved in welfare and development as follows:

You may wonder why I am involved in welfare at all. As the Imam of the Ismaili Muslim Community spread over twenty-five countries, I have necessarily become a student of social problems. Islam is an all encompassing faith and it gives direction to every aspect of one's life. It urges the individual to lead a balanced life, one that strives to accommodate both material progress and spiritual well-being. But no man, woman, or child can hope to achieve this balance in sickness, illiteracy or squalor... [Thus] I have become deeply involved in the provision of basic health and education, which I believe are crucial stepping stones towards mankind's self-realization and growth. (Aga Khan IV as cited in Kassam 2003)

The AKDN is described as a private, international, non-denominational development organization as it does not limit its programs to a particular community, country, or region. In addition, it notes that programs are open regardless of religion, race ethnicity, or gender. Furthermore, it highlights that employees are of different faiths, origins, and backgrounds (AKDN, 2007).

This connection of the role of His Highness as spiritual leader and Imam of the Shia Ismaili Muslims and how it affects his role as the visionary of AKDN is interesting. AKDN literature and leadership point out that $\mathrm{AKDN}$ is non-denominational and open to all, regardless of religion, race and gender, but His Highness also notes that the principles of Islam guide the work of AKDN. For example, AKDN is described as "a contemporary endeavour of the Ismaili Imamat to realise the social conscience of Islam through institutional action" (Sajoo, 2004, p. 99). It is suggested that the integration of Din and Dunya grounds "societal values in the principle of human moral responsibility to the Divine" and consequently "lifts the sense of public and social order to a transcendent 
level” (ibid, p. 100). Various ethical ideals are stipulated as informing AKDN's mandate, these include an ethic of inclusiveness; ethic of education and research; ethic of compassion and sharing; ethic of self-reliance; ethic of respect of life and health care; ethic of sound mind; ethic of sustainable environment: physical, social and cultural; ethic of governance (trust, probity, equity and accountability) (Sajoo, 2004, pp. 101-107). Kassam (2003) in a series dedicated to Islam and ecology examined the AKDN within the context of an ethic of sustainable development and social conscience and writes, "although it draws its inspiration from Islamic concepts, these ethical principles are rational, rigorous, and humanistic in scope" (p. 493). Furthermore, Kassam notes the pragmatic approach of AKDN development strategies, including meeting urgent needs with limited resources, focusing on a multidisciplinary approach (social, economic, cultural), building partnerships (with other NGO, governments, private sector), and harnessing the voluntary sector as well as cultivating grassroots management.

When interviewees were asked about the extent to which ideas such as the inextricable link between spiritual (i.e., Din) and material (i.e., Dunya) are reconciled within AKDN, and whether AKDN would be considered a faith-inspired or faith-based organization, various responses were garnered. At one end of the continuum were individuals who were adamant to demonstrate a separateness of any spiritual component and emphasized the non-denominational nature of AKDN while others offered a more nuanced explanation of their understanding of the role of His Highness as Imam and how that informs the AKDN.

A member of the AKFC leadership provided the following analysis of how one would describe the approach of AKDN. As well, the dual set of institutions those 
dedicated to overall human development versus those institutions focused on the needs of the Jamat specifically were distinguished:

The development of the organization and its existence is certainly inspired by faith, and the values of the Islamic faith about service to humanity, but our work is non-denominational. [...] the Imamat does have a dual set of institutions complementary but separate institutions. So there are institutions that deal with human development at large through the AKDN, but then there are institutions that are just for the Jamat from the Jamat by the Jamat. [...] That is the one area that I think we take a lot of comfort in saying. That there is not too much pressure on the Development Network to focus its work on the development of the Jamat because there are Jamati development institutions in every country where the Jamat resides, and [it] allows us to focus on the broader human development agenda. Of course, you have beneficiaries that straddle both [...]. (interview 2)

Similarly, another individual within the AKFC leadership noted that the interpretation of the faith and how it informs the activities of the Imamat could not be separated. Furthermore, it was noted that although the Imamat can attract people from all faiths to the work of AKDN, it important not to "dilute the idea that it is rooted in a particular understanding and interpretation of Islam" (interview 3).

An executive officer at AKF in Tanzania noted that his personal understanding of AKDN was that it was an expression of His Highness's role as a Muslim leader to contribute to overall development goals. As well, the ethic underlining the work of $\mathrm{AKF} / \mathrm{AKDN}$ was seen not as "religious rhetoric" but something that could be agreed upon by a broader spectrum of people (interview 28). An individual in the for-profit banking sector of AKDN noted that the values and ethics underpinning AKDN were in a sense accepted as universal, so there was no conflict from his perspective. Further noting that the values and ethics keep things "above murky waters" (interview 32). 
Other individuals interviewed articulated the need to separate any aspect of spiritual or faith within the context of AKDN. For example, an individual at the regional level of AKF noted the focus was on programs, so there was no open discussion regarding religion or the intersection of Din and Dunya (interview 29). An individual within the Hospital governance structure noted the importance of viewing the hospital as a secular institution and treating everyone equally. It was indicated that the Hospital may have started out as "faith-based", but it is now moving towards being a secular institution (interview 22). There were some strong personal reactions to this question as was the case with an individual within the for-profit insurance segment. Any idea of faith-based or faith-inspired was equated with trying to influence one's religious affiliation. As such, there was a need for this individual to make it clear that the Aga Khan may be a religious leader, but this does not in any way pressure one to follow Ismaili religious practices (interview 30).

Although the link between Din and Dunya may be seen as a seamless proposition at the Imamat level, there seems to be more variance in the capacity to integrate these concepts at the AKDN institutional level. Also, as described earlier, the capacity to integrate aspects of a multiple logic and straddle multiple sectors flows from the Imamat level. The Aga Khan plays the pivotal role in the vision and direction of the AKDN entities, so the capacity for such a formidable mandate to be reconciled at the various components of AKDN may be more difficult. 


\section{Social vs. Economic}

In a 2003 speech in Kenya describing AKFED the Aga Khan IV stated the following:

AKFED, $[\ldots]$, is therefore neither a charitable foundation, nor a vehicle for the personal wealth of the Ismaili Imam of the time. It is a for-profit, international development agency that, because of its institutional background and social conscience, invests in countries, sectors and projects, on criteria far different from those of a straightforward commercial investor. Investment decisions are based more on the prospects for better lives for the constituencies of people that will be impacted by the investments and their results rather than on bottom line profitability. AKFED does seek to generate profits, but they are entirely reinvested in future development initiatives. (AKDN, 2007g)

Ghani and Lockhart (2008) note the willingness of AKFED to invest in

Afghanistan after September 11, 2001, when most investors were cautious of the country. According to the authors, this strategy of early investment in the social fabric of "failed states" has led to profits (p. 50).

Kaiser argues that the management techniques (i.e., efficiency and surplus generation) and structure, particularly the Aga Khan health facilities and to a lesser extent the Aga Khan schools in Tanzania is similar to a depiction of a "post imperialist transnational corporation" (1996, pp.12-13). Although he notes that for Aga Khan health and education services, when a surplus is generated, it is reinvested instead of a source of dividends for corporate shareholders (ibid.). Also, the international support via financial, material and labour resources (volunteer, non-volunteer) further the effectiveness of the local and national initiatives (ibid, p. 65). According to Kaiser (1996), this strategy allows the Aga Khan health and education initiatives to deliver non-profit social services without being completely reliant on external donor funding. However, he notes that the 
balance between economic self-sufficiency and social goals creates a tension in the types of services offered (Kaiser, 1996, p. 68). These potential tensions will be further explored in the Tanzania case study.

The Social component is interesting because the not-for-profit sector is usually not equated with a focus on surplus generation. The initial costs and often the costs for infrastructure improvement are provided by the Imamat level. As such, the capital costs are not expected to be covered by the non-profit agencies. This takes away the financial burden and allows the hospitals and schools to focus on mechanisms to sustain the operation and generate revenue and surplus that will maintain the service for the longterm. This emphasis on surplus in a non-profit environment brings up the issue of how a balance is maintained to ensure that those individuals that may not be able to afford the services have access. This can create a situation where individuals that have the resources become the target market for the non-profit entities in order to generate the surplus. Thus, individuals who cannot afford the services, either have to do without, utilize sub-par services or in the context of the Ismaili community rely on a donor driven system at the community level.

Investment in economic development is seen as a long-term endeavour and venture capital provides the means for capacity building. The economic component of AKDN as described by His Highness is one where AKFED decisions are not based on a typical business model. The focus in on creating equity partnerships that draws foreign investment which otherwise may not engage in large-scale development initiatives in developing countries (Ruthven, 2011, p. 211). Many private sector investors may 
consider investment too risky in fragile environments, but for various AKDN initiatives it may be a manageable risk because of its long-term experience in many countries.

This idea of engaging in long-term investments in areas where AKDN chooses to operate was reiterated in an interview with the AKF General Manager. It was explained that the focus of AKDN was not on having single projects or an exit strategy in mind, but the goal is to make investments in people and institutions as well as create institutions (interview 1). As such, it was noted that His Highness shares a timeline for activities that usually spans ten to twenty-five years depending on the country, and this is even before a determination is made regarding the range of activities or how it will be financed (ibid).

The engagement in large-scale infrastructure building is seldom considered the work of a development agency, and it brings to the forefront the possible shifting of approach to a more economic centric framework, especially now that funding includes government, donors, larger foundations, and private equity groups. As such, there is a need to assess to what extent an economic logic may be overtaking or squeezing out the logic at the social level that is rooted in the community.

The AKDN model is premised on self-reliance, building capacity, and long-term investment. As such, user fees are part of the model because the amount that the Imamat level can provide is limited. However, the fees even if there is a level of subsidization may not be feasible for a large segment of the population. Thus, what trade-offs are acceptable to maintain a surplus model within the context of welfare delivery needs examination.

Wood and Malik (2006) use a framework of state-market-family and community at the domestic and supranational level to examine the extent to which social insurance 
and sustained welfare transfers are of relevance in the Northern areas of Pakistan. The authors examine the Aga Khan Rural Support Program (AKRSP) in the Northern AreaChitral region over a twenty-year period, and note that although there has been progress in enhancing subsistence issues, vulnerability, insecurity, and poverty continue for many. For example, different categories of households have emerged, e.g., graduated from poor, graduated but still vulnerable and continuing poor. The authors note that initially AKRSP focused on an approach to address poverty that would be considered productivist. This included addressing productivity infrastructure, providing skills training and access to micro-credit products. However, as different categories of households emerge, the authors note the importance of considering the relationship between productivist strategies and social protection (i.e., safety nets and transfers). Also, another issue is whether such social protection is embedded in programs or is designated as funds for emergency situations (pp. 113-117).

According to Wood and Malik (2006), a broad-based embedded social protection mechanism does not often come into play in countries with a low tax base and a large informal employment sector. As such, they argue, it becomes more relevant for organizations like AKRSP to question whether their strategy should be limited to economic development (i.e., market expansion) or entail a combination of capacity building and forms of social protection (i.e., enhancing indigenous practices, targeted funds etc.) (p. 114). The authors highlight AKRSP's introduction of a Poverty Fund as a mechanism to address issues of social protection. However, they note that the burden of sustained welfare transfers (ongoing money and in kind) still remain with households and kin groups who themselves are experiencing their own levels of vulnerability and poverty 
(p. 116). This dilemma of having limited funds and the extent to which social protection can be a comprehensive undertaking within a framework of self-reliance and independence will be examined in the case study chapters. In a sense, the focus on selfreliance and independence places the onus on the individual to secure his/her welfare needs, and then having targeted programs for those that need help rather than having comprehensive social protection programs that may encompass a more rights based perspective of welfare.

\section{Logic of AKDN /HH/ AKDN Relationship to State}

The logic of the Imamat level has continued from the days of Aga Khan III to encompass a state-like quality engaging in various forms of diplomacy. For example, Aga Khan III was considered a statesman by many and was appointed President of the League of Nations in 1937. The current Aga Khan continues the legacy of maintaining connections and relationships at the national and international levels. This provides a certain level of legitimacy that governments are willing to engage with for development purposes. This is further reinforced when His Highness is invited by world leaders to celebrate his Imamat, as was recently the case, or is acknowledged by awards, both individually and for the agencies of AKDN. For example, the Aga Khan was awarded with the honorary Companion of the Order of Canada in 2005.

The capacity to demonstrate high quality services is another reason that puts $\mathrm{AKDN}$ in a position to garner government support and resources from donor agencies, private foundations as well as its capacity to create equity partnerships. This multi-fold strategy shows the comprehensive logic of the Imamat level and allows for long-term 
sustainability. It also highlights the need for the Imamat level and by extension AKDN to balance the demands of various constituents/stakeholders such as governments, donors, private-sector and the community level.

There are benefits that AKDN acquires by virtue of having formal agreements with many countries where AKDN operates. These agreements allow for varying degrees of diplomatic privileges. In addition, many countries have a permanent AKDN representative who is tasked with paving the way for various AKDN agencies in their relationships with relevant Ministries to ensure projects move forward. The AKDN representative office is like having a state embassy dealing with issues of engagement with relevant governments. As such, the Imamat level has inroads in the various countries and can more effectively participate in the economic and social issues of a country. These formal relationships provide the basis to engage in project partnership. However, the extent to which AKDN and the Imamat level engage in co-production of services with government will be explored in more detail in the case study chapters. It is important to consider strategies such as keeping governments at an "arms length" from projects as suggested by Najam (2006) to ensure control over a project and keeping a distance from any issues of government instability or corruption. Najam (2006), in examining the relationship of AKRSP in Pakistan with government notes that influencing government has been the strategy rather than directly opposing government. Furthermore, the author notes AKRSP plays the role of an advocate for policy change, either directly or, for instance as an innovator in implementation.

AKDN is positioned as a catalyst for change in areas such as education, health, infrastructure, policy, and curriculum assistance. As a result, AKDN is seen as a leader 
and its expertise is sought by government. The capacity to draw foreign capital to initiate and sustain large scale infrastructure projects and create jobs in countries where it operates are other reasons for the willingness of governments to engage in agreements of protocol with the Imamat. Also, governments seek its support or make it conducive for it to start infrastructure projects because the government is lacking the internal infrastructure or the capacity to do so. However, when this void is filled by an entity other than government, it can have the effect of governments choosing to opt out of crucial social protection functions and staying on the sidelines.

This capacity for the Imamat and his representatives to engage at the national level and international level cannot be underestimated. The ground level representation allows for a level of understanding of the different development needs and adds relevance and in turn legitimacy to engagement at the national and international levels. The engagement of AKDN with government with its state-like elements enables it to create a level of assurance as well as maintain an iterative relationship for future engagement. The transnational nature of the AKDN and the relationships the Imamat fosters makes it conducive for involvement in the service delivery of development, but it goes further into the realm of policy and ideas. The AKDN is able to engage with multiple stakeholders at international, regional, national, and local levels and this can be beneficial in a competitive development environment. As well, a loyal base of Ismailis engaged in resource generation and professionally within the organization creates a level of stability.

The experience in countries at different phases of development as well as during different regime control provides AKDN/Imamat level with a unique perspective into the development and economic needs of various countries. AKDN is involved in many 
countries around the world and maintaining political neutrality is seen as important.

However, this stance does not exclude influencing government in areas of interest to AKDN and setting the stage for the development process itself. For example, an "enabling environment" has been the subject of different country, regional and international conferences. At one such conference focusing on economic partnership between Central Asia and Europe the Aga Khan IV stated:

A sound enabling environment must create a favourable framework in which people's energy and creativity can be motivated, mobilized and rewarded. This framework should embrace such conditions as political stability, safety and security, citizen rights and predictable democratic practices. [...] These concerns are largely the responsibilities of government, but effective governmental efforts can take us only so far. And that is why I so often talk about the role of "Civil Society"; the capacities of the private sector, and the value of partnerships among these various institutions. (AKDN, 2007j)

The programs and services that are provided by the AKDN and the extent to which government is involved are not at the level of co-production. However, as discussed, there is a sense that AKDN at some level tries to keep government at a distance because of issues related to instability or not wanting any potential government constraints in decision-making that may influence the trajectory of projects. As well, moving to a more regional approach may create different levels of priority than perhaps engaging in co-production with a particular state.

A senior member of AKF in Geneva noted that although the work of AKDN considers the overall country strategy, they are not willing to give control of financial resources to the government for development initiatives (interview 1). He stated that, "We have a relationship. It is one that we hope is cordial and interactive, but it is also one that keeps us a little bit away from some of the terms [i.e., co-production] that you used 
might imply." The issue, it was explained, was not because of concerns related to corruption, but rather to ensure development that is distinctive and will not struggle like perhaps a government institution (interview 1). There were initiatives that were described as public-private partnerships whereby AKDN would sign an agreement with government for a specified period (e.g., ten years) to help develop and manage a particular institution that was critical to the country, but the government would continue to own it and put in the revenue (ibid.).

The relationship AKDN has with government in many respects seems to be that

of initiator and catalyst of projects or ideas (also see Ruthven, 2011; Najam, 2006). There is a sense that the dynamic with government is managed very carefully by the Imamat level and any engagement with government needs to fit within the vision of the Imamat rather than the relationship being orchestrated and controlled by the state.

\section{Regionalization}

Although AKDN may be moving in a regional direction, this has not been the case with donor countries or private donors. The emphasis is still country specific development. A regional approach can allow for harnessing institutional capacity, decreasing duplication of services and addressing welfare needs that cross national borders. The capacity for a regional outlook both in the context of community institutions and the Broader AKDN will be explored in the case studies in more detail. 


\section{Conclusion}

AKDN is more readily described by what it is not rather than what it is. This is predominately because the organization is a composed of a hybrid logic that is being directed by an Imamat level with the capacity to blur the lines between traditional welfare segments. Because AKDN is not a government institution, some may find it falls under the umbrella of NGO or private sector, but we need to look at the dynamics of the organization and the role of His Highness to fully understand its scope. The experience in East Africa of the precursors to AKDN is over a hundred years old. This is in contrast to some NGO's that function in countries on a short-term basis or are tasked with addressing a particular crisis. The administration costs are minimized compared to other NGO's because of the Ismaili volunteer capacity as well as the initial infrastructure funding and future capital construction costs being absorbed by the Imamat level. This creates the foundation for initial stability, and thereafter the focus is on a type of "para-company" model for the social sector. This "para-company" set-up for the social side is different from what is traditionally considered a non-profit organization. The focus is on getting the companies to the break-even point, and then focusing on generating a surplus that can be reinvested into the service company. This creates an atmosphere that is thought to be conducive for self-reliance and ultimately independence. The complications of this set-up could include too much of a focus on user-fees and leaving some individuals to fall between the cracks because of lack of resources. Also, the logic of the economic may overshadow the social aspects of the para-company composition such as capacity building and poverty alleviation. 
AKFED entities focus on profit generation. The regions where the AKFED operates are often considered risky by other private-sector entities. However, the longterm outlook and previous experience in many of these fragile environments create a different decision-model for AKFED in terms of engaging in a particular venture. As such, placing AKDN in the category of the private-sector or a transnational corporation is inadequate.

AKDN is also not described as a faith-based organization. However, because the head of the organization is the spiritual leader of the Ismailis, the AKDN is described as the "social conscience" of Islam, and the Aga Khan speaks of the inextricable link between Din and Dunya, there is a need for a more nuanced understanding. It also points to the difficulty in making a separation from the precursors of the organization being rooted in a religious faith to one that is now focused on a broader mandate. In addition, it puts into context the push and pull dynamic between the Ismaili community level and the overall AKDN.

The ability for the economic side and the social side to be mutually reinforcing is another aspect of AKDN's makeup. The possibility of AKFED agencies to subsidize services on the social side exists, but to what extent this is happening on the ground needs to be explored. Also, the infrastructure and stability that the social components provide in the area of health and education allows for a level of stability to start up large-scale business ventures. When looking at components of AKDN in the profit and non-profit segments, the use of fees articulates a vision of welfare that is rooted in self-sufficiency and not being dependent. However, as will be explored in the case studies, there are implications for those that are the most vulnerable. 
This focus on the broader society has intensified engagement with states, and having formal agreements in place to some extent privileges AKDN as a "broker of choice". Although the precursors of AKDN entities in East Africa were initiated in the context of the community, the beneficiaries as demonstrated in the Tanzanian context are not focused on the Ismaili community. Individual Ismailis continue to be involved with AKDN in various capacities but not as representatives of the community as a whole. The capacity to tap into the multiple segments allows for an acceleration of trajectory because the community level is not the sole constituency. The evolution of the AKDN components may be rooted in community, but at the same time, there is a need to de-link in some respects to have the capacity to take on a new form. However, the capacity to address vulnerabilities in the community context when issues of resources both volunteer and financial are limited brings to the forefront whether de-linking of the community (or those individuals that are unable to thrive in a market driven environment) has gone too far.

The broad range vision that incorporates a transnational perspective with a regional focus is a demonstration of trying to negotiate multiple constituents and engage at the international, national, regional, and local levels. This transnational capacity was initially generated from the Ismailis community itself and precursors of AKDN being able to tap into the resources and serve the needs of Ismailis in various countries. As well, the focus on promoting regional co-operation highlights a transnational perspective rather than one that is state-centric, the predominate lens for welfare provision.

AKDN may seem like a complex set of contradictions, especially if an attempt to understand the organization is from the lens of distinct sectors (i.e., state, market, third 
sector) and/or confining it to a particular scale (i.e., international, national, regional, local). However, the dual mandate at the Imamat level and having a transnational perspective allows for maneuvering in a space that is not confined to a particular sector or scale. Nonetheless, as demonstrated with the signing of protocol agreements with governments and the accompanying diplomatic prestige, there is the capacity to speak the language of a particular sector (i.e., state). As well, the Imamat level engagement with issues such as creating an enabling environment, governance, and issues of democracy by extension put AKDN entities in a space of trying to influence policy direction and capacity. 


\section{CHAPTER 4: CANADA CASE STUDY}

\section{The Ismaili Community in Canada}

The initial migration of an Ismaili to Canada was in 1952. This individual was a student from Pakistan pursuing educational opportunities in Canada (Karim, 2011a, p. 279). In the 1960's and early 1970's there was some migration of Ismailis from South Africa (during apartheid) and East Africa because of issues of political stability and for economic opportunities (Karim, 2011b, p. 215). In 1972, the expulsion of "Asians" including Ismailis from Uganda by then President Idi Amin resulted in many Ismailis being relocated to various countries including Canada. Aga Khan IV negotiated with leaders of various western nations to assist Ismailis during this time, and his previous relationships with individuals such as Prime Minister Pierre Elliot Trudeau was instrumental in achieving a safe space for Ismailis. These high level relationships provided an initial level of confidence for Ismailis in Canada. This period also cemented fear of possible future instability in other parts of East Africa, so migration from these areas also became a consideration. Ismailis from Uganda arrived in Canada prior to any infrastructure such as a permanent Jamatkhana or Council structure. However, Ismailis that were already residing in Canada at the time assisted with living in a new country.

This community link was crucial as Ismailis from Uganda lost their businesses and possessions and were considered refugees without a home country. In Canada, the government provided a basic living allowance and any further financial support was provided by family and community members. 
In subsequent years, other Ismailis considered the benefits of migrating to Canada for reasons of security, economic opportunities and advanced education for their children. The choices for tertiary education were limited in East Africa, and the guidance of the Imam prioritized education as an important factor for enhancing economic options. Over the years, Ismailis became more organized with the implementation of the Council structure and the construction of permanent Jamatkhanas. It is estimated that by 1975 there were approximately 10,000 Ismailis in Canada, so the need for community infrastructure became more relevant (Nanji, 1983). It was after the visit of the Imam to Canada in 1978 that a concerted effort was made to address issues of governance and infrastructure (ibid.). Starting in the 1990s, Ismailis immigrated from Afghanistan and other parts of Central Asia because of instability in that region. A number of protocols were in place to facilitate the immigration of Ismailis from Afghanistan to Canada. Ismailis have emigrated to Canada from different countries including various parts of Africa, India, Pakistan, and various European countries. Today, the number of Ismailis in Canada is estimated at between 70,000-80,000 (Karim, 2011a, p. 265).

Emigration of the Ismaili community has been a prominent feature in its history and being a minority community in some cases with restricted access to welfare has influenced their approach to social provision. At the forefront are the values of selfreliance and independence. It has been an underlining theme from a colonial context to environments where state welfare provisions are available (i.e., Canada). The need to see one's community as not dependent on the state is also a feature of other minority faith groups that have migrated to Canada. Jansen (1981) in his dissertation titled "The Limits of Liberty in Canada: The Experience of the Mennonites, Hutterites, and Doukhobors", 
explored the idea of communal liberty vis-à-vis the state in Canada. He noted that although these communities are different in their religious backgrounds, their negotiated relationships with the federal and provincial governments have similarities in trying to maintain their self-reliance and independence. Each of these communities reflect different religious movements that rejected conformity in their countries of origin and as a result migrated to North and South America. In the case of Menonites and Hutterities it was Germanic Europe (i.e., Austria, former East and West Germany, Netherlands and Switzerland) while for Doukhobors it was Russia (ibid.). During initial points of migration in the later part of the $19^{\text {th }}$ century, the Canadian state needed individuals with agricultural backgrounds, so there was an initial willingness to allow for a high level of communal liberty (ibid.). The key areas outlined by Jansen (1981) included holding land communally, control of schooling, not having to serve in the military, and having control of community material and welfare provision. However, these liberties were not entrenched and had to be re-negotiated.

In some ways, the need to be self-reliant and independent is reflected in the Ismaili experience, but there are some important distinctions. For example, there was a level of dependency on the state when Ismailis came to Canada as refugees in the early 1970's. As well, there is no communal ownership of assets - those assets are held at the Imamat level. More recently, the Council for Canada (CFC) is examining ways to work with government in areas that would be beneficial to the welfare of the community. At the Imamat level, there has been an ongoing relationship with the Prime Minister's Office, CIDA and more recently in its partnership with the Canadian government in the Global Centre for Pluralism. Thus, in the Ismaili context, although there is this impetus to 
be self-reliant and independent, there is also a level of strategic engagement with the state.

\section{Changing Demographics}

The composition of Ismailis from the 1950's to the 1990's was predominately from East Africa, South Africa, Pakistan and India representing mainly Khoja Ismailis. However, in the 1990's there was a change in demographics with the sponsorship of Ismaili Afghan refugees (interview 5). The language, culture, and practice of Ismailis from Central Asia including Afghanistan are distinct from the Ismaili Khoja population. Several Board Chairs noted that with this shift in demographics, there is a need to examine how things within the community have been structured and to take a more inclusive look at programs and the specific needs of this new population. As well, important issues regarding leadership representation and the potential challenges needs consideration. An interviewee noted that the role of the Council was to create a space for differences in culture and background with a focus on integration versus assimilation (interview 5). One interviewee who had previous experience at the local Council level in Social Welfare indicated that the experience provided a good sense of where the issues and priorities were within the Jamat. It was noted that by working closely with families at the grassroots level, there was a better understanding of the multiple vulnerabilities being faced, especially by Afghan families. The need for individuals within the Jamat that are facing multiple vulnerabilities to be a priority was highlighted. The Imam's guidance was also pointed to for ensuring that the Afghan Jamat is a priority. The issues faced by members of the Khoja Jamat were also seen as important, but it was pointed out that the 
Khoja Jamat did not face the same language issues nor did they come from regions of the world where there was prolonged conflict (interview 10).

Another area where issues of demographics come into play is the actual governance structure of the Ismaili community within Canada, as the leadership has historically come from the Khoja population. As described by a member of the leadership, there is an effort to be more beneficiary focused and culturally representative in leadership as well as in the service delivery of the programs.

There is a real strong effort to ensure that we are very beneficiary focused [and] that beneficiaries are represented culturally in the leadership. [...] As well, [there is better] represent [ation] in the various committees and delivery organizations of the community, so we are not playing a paternalistic role [...], but we are hearing from beneficiaries [of] what might be appropriate to them, either in terms of their issues or in terms of solutions to address those issues. [...] we have a diverse community with a majority and then a minority, obviously representation needs to be managed [...] I see that [representation] as a responsibility of the leadership to ensure that those voices are being heard on a constant basis [...]. (interview 6)

Since the initial migration to Canada, the number of Ismailis in Canada has also seen an increase. This has implications for the capacity of community structures to meet the needs of a growing and diverse Jamat. Other aspects of changing demographics were the needs of an older Jamat, and the role fathers played in child-care given the level of professional equality between men and women in the younger Jamat. Also, the need to address competing demands on one's time and capacity to volunteer within the community was highlighted (interview 4).

The issue of engagement in the day-to-day aspects of the Ismaili community and how this continues when some Ismailis have lived in Canada for over fifty years is one that may be described as a continuum from a compartmentalized engagement to one that 
maybe more heavily involved in the religious and community affairs, including service by volunteering within the community and in broader contexts. In the Canadian context, there is perhaps more anonymity as there is a larger population than in Tanzania and often individuals may not personally know one another. If one attends the Jamatkhana regularly, is involved in volunteer activities, and is engaged in the programs and services offered by the Council and Boards, there may be more opportunities for a sense of community. However, engagement within the wider Canadian context and balancing time between work and family can to some extent lead to compartmentalizing rather than living the notion of a balance between Din and Dunya (see Dossa, 1985). This is not the focus of the dissertation, but understanding how compartmentalization may affect engagement within the community and the implications for the development of welfare support are important. In addition, one could argue that the tie of the community is linked more to the Imamat level. Thus, rather than an internal link that coalesces the community level there is an external link to the Imamat level that is reinforced by allegiance.

\section{Previous Studies of the Ismaili Community in Canada}

Various studies of the Ismaili community in Canada have focused on the individual or community level. A brief overview of some key studies will provide a grounding for previous research and a means to orient the current study.

Dossa (1985) in examining the daily lives and rituals of Ismailis in Vancouver, particularly women, argues that factors such as increased engagement in spaces where social relationships are confined, entry of women in the labour force, and the changing dynamics of relationships between youth and adults as well as the elder members of the 
Jamat has introduced a level of compartmentalization. Aspects of spiritual and material life were seen as more complementary, but as argued by Dossa (1985), there is now an introduction of compartmentalization that requires choices between engagement in "core community" versus broader societal activities.

Keshavjee (2004) in her study, "The Redefined Role of the Ismaili Muslim Woman Through Higher Education and the Professions," seeks to locate professional Ismaili women in the spectrum of Muslim women and in Islam generally. She concludes there is no quintessential Ismaili or Islamic women, but points to the role of higher education and the interpretation of the faith by Ismaili Imams pertaining to the role of women and the importance of education as crucial factors in negotiating traditional roles for the women in the study.

Mukadam and Mawani (2006) study issues of identity of second-generation Ismailis in London, England and Toronto. They argue that identity is not fixed, but rather there is space and freedom for creating multiple coexisting and evolving identities. They found that second-generation Ismailis remain linked to their cultural heritage.

Matthews (2007) in her dissertation, "Ismailis in Canada: Locations of Subjectivity," explores the concepts of diaspora, transnationalism and cosmopolitanism at the individual level in Canada, specifically Ontario and Quebec. The emphasis was on subjectivity of identity, so the focus was on self-reflection by a group of Ismailis interviewed about their lives and experiences. As well, the researcher engaged in participant observer data gathering for the study. Her previous relationships with individuals in the community helped to provide access. A key conclusion of the study is the capacity for a simultaneous local and global outlook based in a religious identity. 
Karim (2011a) provides an analysis of the intersection of tradition and modernity with a focus on the engagement of the Ismaili community in contemporary Canadian society. He argues that Ismailis in Canada find themselves engaged in "a tripartite 'dialectic' of tradition, modernity and postmodernity" (p. 287). As such, the community is occupying a space whereby "they are simultaneously re-living certain aspects of their long history and charting out courses in contexts that are very different from those they encountered previously." (p. 289).

Although studies that focus on the individual and community levels are important, it is also beneficial to examine multiple scales simultaneously to tease out the broader set of interconnections. The aim of this dissertation is to examine issues of welfare production considering the authority of the Imam, the Ismaili community welfare structures and the relationship to broader AKDN initiatives in both a developed and developing world context. As well, the tensions of having a logic of hybridity at the Imamat level that engages with multiple constituencies at the community, national and international level is explored.

\section{Authority of the Imam}

As noted in the Ismaili Background chapter, the authority of His Highness the Aga Khan in relation to his community is at the heart of the Ismaili Constitution. It notes "an absolute and unfettered power and authority with respect to religious and jamati matters of the Ismailis" (Aga Khan IV, 1986, p. 9). How the Imam's authority is understood from a leadership perspective in the Canadian context was explained in a number of ways. The Imam was described as providing guidance rather than imposing solutions (interview 
4). A former senior member of CFC leadership highlighted that the performance of Council is gauged against defined objectives with the Imam providing guidance. Although the Imam was considered receptive to ideas, the leadership had to clearly demonstrate and rationalize their course of action, and the Imam would sometimes ask for another option that could result in a better outcome (interview 5). Ultimately, the Imam was described as being the final authority in decision-making (interview 5). One Board Chair voiced a level of frustration, and he indicated that there was not a sufficient level of dialogue between leadership and the Imam because data collection was poor. This resulted in not being able to provide adequate options to the Imam for decisionmaking (interview 13). Another senior member of the Council leadership stated:

[...] religious and Jamati matters, no question and no debate. In terms of governance issues, [however], Hazir Imam expects us to bring analytical and critical thinking to the table. There is no kind of spoon-feeding. This is what you've got to do. He makes sure we're thinking through the issues. [...] [The solutions] might be very different than the solutions that might be relevant for communities that we don't cover or are not responsible for. $[\ldots]$ There wouldn't be good governance if there wasn't any critical thinking allowed to flourish and to propose programs that are good for the communities that we are responsible for. (interview 6)

Another area that speaks to the authority of the Imam with respect to his community is regarding the strategic direction of the community and any substantive policy shifts. Many interviewees in the CFC attributed the move from a segmented model to thinking about issues thematically as based on the guidance from the Imam. This would entail looking at a particular theme, for example, poverty, early childhood development, or the elderly and determining which Boards were relevant (i.e., Education, Health, Economic Development, Social Welfare, Settlement, Women's Development and Poverty etc.), and then deciding how the Boards could work together as opposed to an 
individual having to approach each Board separately. As such, instead of working in a segmented manner there is a push from the Imamat level to focus on a more collaborative approach and create the capacity to address multiple vulnerabilities simultaneously.

The fact that the Council and Boards are accountable to the Imam above the Jamat is clear in how issues related to funding are addressed. There is an independent audit component, the Grants and Review Board (GRB) that is separate from the Council and has a mandate from the Imam to audit all the Board programs as well as to provide a consultancy function (interview 8). The focus is on efficiency and ensuring that objectives are met. The GRB is accountable to the Imam rather than the community, so the community itself is not privy to the details regarding program funding. As described by a member of the CFC leadership, the funding from the Jamat is disclosed as percentages for the various programs and services. There is, for example, no detailed annual report provided to the Jamat because the responsibility of the Council and Boards was seen as fundamentally to the Imam (interview 6). As such, it was the Imam that ultimately approved the programming and strategies for the Jamat as outlined in the Constitution. Thus, it was stated that, "although we are responsible for delivery [of services] to the Jamat, ultimately our accountability would be the Imam" (interview 6).

\section{Structure of the Council and Other Bodies}

The Ismaili Tariqah and Religious Education Board (ITREB), the Conciliation and Arbitration Board and the Grants and Review Board are all separate entities and their mandates are not directly linked to the aims and objectives of the Council. These Boards are directly under the guidance of the Imam. The other Boards (Economic Planning, 
Education, Health, Social Welfare, Youth) were initially set-up with individual mandates, but there is a move towards more cross-links and consolidation between the Boards. However, given these Boards were initially independently set-up by the Imam and ultimate accountability is to the Imam, the capacity for the National Council executive to be a pinnacle of coordination by proxy for the National Boards is not clear-cut.

The Council structure in Canada includes a National Council and six Local Councils. The composition, functions and duties of the Local Councils are ascribed by the National Council. The focus of the National Council is on strategic and policy issues while the Local Councils focus on program and service implementation. I will be focusing on the National Council for this dissertation.

Table 4-3 National Council and Boards in Canada ${ }^{16}$

\footnotetext{
${ }^{16}$ There are also relevant Local Councils and Boards based on the size of the Ismaili population in different parts of Canada. The focus of these Councils is on implementation of programs and services. For example, there is an Ontario Council for Canada and Ottawa Council for Canada that are tasked with program implementation.
} 


\begin{tabular}{|c|c|}
\hline Council for Canada (CFC) & $\begin{array}{l}\text { The National Council focus is on strategic } \\
\text { and policy issues. It also acts as a } \\
\text { coordination body for Local Councils. }\end{array}$ \\
\hline Grants and Review Board (GRB) & $\begin{array}{l}\text { An independent audit component. It has a } \\
\text { mandate from the Imam to audit all the } \\
\text { Board programs as well as provide a } \\
\text { consultancy function. }\end{array}$ \\
\hline $\begin{array}{l}\text { Conciliation and Arbitration Board } \\
\text { (CAB) }\end{array}$ & $\begin{array}{l}\text { An independent dispute resolution } \\
\text { function. It overseas the regional CAB's } \\
\text { that provide dispute resolution services to } \\
\text { community members. }\end{array}$ \\
\hline $\begin{array}{l}\text { Ismaili Tariqah and Religious } \\
\text { Education Board (ITREB) }\end{array}$ & $\begin{array}{l}\text { An independent Board that oversees the } \\
\text { religious education within the Jamat. }\end{array}$ \\
\hline National Health Board (NHB) & $\begin{array}{l}\text { Oversees issues related to the health of the } \\
\text { Jamat. There are no provisions for health } \\
\text { care rather it focuses on prevention, } \\
\text { education, and assistance in navigating the } \\
\text { health system in Canada. }\end{array}$ \\
\hline National Education Board (NEB) & $\begin{array}{l}\text { Directs the support for education } \\
\text { excellence at all levels. This includes } \\
\text { administrating scholarships, tutorial } \\
\text { services and language skills programs. }\end{array}$ \\
\hline Economic and Planning Board (EPB) & $\begin{array}{l}\text { Facilitates the dissemination of relevant } \\
\text { economic information, potential investment } \\
\text { in industries, promoting savings, and } \\
\text { formalized mutual assistance. }\end{array}$ \\
\hline Social Welfare Board (SWB) & $\begin{array}{l}\text { Focuses on enhancing self-reliance of } \\
\text { individuals and families to increase their } \\
\text { quality of life. Coordinates the programs } \\
\text { and services for vulnerable populations of } \\
\text { the Jamat. }\end{array}$ \\
\hline Youth and Sports Board (YSB) & $\begin{array}{l}\text { Oversees issues of relevance to the youth } \\
\text { of the Jamat. This includes social and } \\
\text { health issues (e.g., active living), and issues } \\
\text { of identity. }\end{array}$ \\
\hline $\begin{array}{l}\text { Women's Development Portfolio and } \\
\text { Poverty }\end{array}$ & $\begin{array}{l}\text { Oversees mentoring, career development } \\
\text { and overcoming barriers that may be faced } \\
\text { by women of the Jamat. }\end{array}$ \\
\hline Settlement Portfolio & $\begin{array}{l}\text { Tasked with providing comprehensive } \\
\text { assistance to new Canadians. The focus is } \\
\text { on basic needs, adaptation, leadership } \\
\text { development, and integration. }\end{array}$ \\
\hline
\end{tabular}


The structure of the National Council and how it collaborates with members of the Jamat was acknowledged as being hierarchical. However, there is an effort to engage in more consultation. The National Council executive is composed of the President, the Vice President, and CEO. The various National Board Chairs as well as Portfolios are ex officio members of the National Council. There are six regions in Canada with Local Councils and relevant Boards where necessary. The Council is composed of a large group of volunteers with a small nucleus of paid staff (interview 4). The success of the Council in engaging fully with members of the Jamat and the level of coordination between Boards and portfolios ranged in responses from interviewees. According to one member of the CFC executive team:

I think it's hierarchical for sure. The Constitution sets out the hierarchy. I think governance is more flat, and there is a real effort to [...] build consensus because in a community like ours or any community it is very difficult to have single point decision-making. [...] you are going to get it wrong if you don't consult, and so for us, from a governance perspective, it's very very important that we get as broad a view on an issue before [...] the decision is made. [...] (interview 6)

[...] the Council has as part of its components the Education Board, Economic Planning Board, Social Welfare Board, and then the CFC would oversee all the activities that are being planned, undertaken as well as the strategies behind these within each Board. So coordination is a heavy responsibility of the Council. [...] there is the risk of course that there will be no or low coordination because the Boards are independent organizations that are set up in the Constitution. [...] And so, coordination is critical to our own success and tracking the outputs that will result in outcomes. (interview 6)

One Board Chair noted that the level of consensus within the Council structure has evolved, and although some Boards and portfolios may have more weight, this was seen as a natural outcome of any group. However, overall the organization in terms of its governance was considered flat (interview 14). Another Chair noted that at both the 
national and local level, there was a need to include a grassroots perspective. The interviewee stated, "if you are 400 feet high, you don't have an understanding of the issues at the grassroots level, and unless attempts are made to connect with the vulnerable, poverty is invisible" (interview 10). Another Chair noted the need for improvement in the articulating the roles, responsibility and accountability of the organization, and for more efficiency in the approval process (interview 13). Many Chairs noted that the move to a more thematic outlook was a positive change and provided more opportunities for collaboration and synergy as previously each Board focused on its own specific constitutional mandate. Although there was coordination before, it was more on an ad hoc basis. As well, a thematic model was seen as allowing for more focused programs and minimizing overlaps and the strain on resources. However, how the thematic approach was fairing was still too early to determine.

\section{Rationale for Programs and Services}

In the Canadian context, there are more options available to Ismailis for welfare like state programs and services or other external services that are available to the general population. However, there is a tendency within the Ismaili community to want to ensure self-reliance and independence and not rely on the state or external services. This can place a heavy burden on community structures. As explained by a member of the CFC leadership:

I think it is all based on building [and] having a strong civil society organization, [and] realizing that we like other communities are independent. We don't want to be dependant on [the] state. The state can't necessarily provide everything for everyone. We have a community that is [...] bound together by its affiliation to the Imam, and so it's appropriate $[\ldots]$ to have an institutional structure to ensure that members of the 
community who needs assistance are given that assistance without having to rely on [the] state, although we can leverage [the] state. (interview 6)

However, the need to be cognizant of ensuring a balance between not being seen as dependent and over burdening the internal structures was expressed. One of the Board Chairs noted that there is no internal capacity to create jobs, but there is an expectation to do so, and this can create a strain on the Board's resources. As well, given the alternatives in Canada for programs and services, the Chair questioned the rationale for the community not fully accessing the available services. However, he did acknowledge that issues of comfort and familiarity come into play when accessing services in a community context (interview 13).

The issue of self-sufficiency and self-reliance was at the core of several interviews with the various Board Chairs. The other aspect that came to the forefront in terms of the rationale for programs and services were the ethic of volunteerism within the Ismaili community, and the coherence of the community based on their connection to the Imam. This was described as follows:

I think that it is all about voluntary [service]. It's all about community coming together to help. So accepting the fact that I have a responsibility to my family and my community is in my view one of the major drivers, and an ethical underpinning in Islam and clearly [an] ethical underpinning in [the] Shia Ismaili [tradition] which [is] [...] guided and driven by the Imam. Obviously, based on principles outlined in the Quran, and so that is an underlining driver of absolutely everything that we do. [...] the volunteer element doesn't just come with [needing] to do a professional task, [but] it comes with heart and compassion and interest and [the need] and desire to fulfill an objective that is bigger. (interview 6)

The way programs and services are formulated include a targeting component as well as services that are available to the wider Jamat. The issue of whether services provided by the Council and Boards would be considered means-tested versus falling 
more on a rights based formulation was not clear-cut. The programs covered both specifically targeted programs as those mandated by the Social Welfare Board as well as programs that were open to the wider Jamat. Because self-reliance and independence are key components of the formulation of welfare in the Ismaili context, members are not provided with a certain minimum rather the onus is on the individual to secure his or her needs and ask for help if needed. There is also a level of support from the state in the Canadian context. There are supplements in the community context for issues such as early childhood education, needs of the elderly and general issues of economic development. As well, the more recent focus on a thematic perspective incorporates issues of quality of life, which allows for a concentration on individual aspirations and providing assistance to achieve the articulated goals.

However, only those individuals that are unable to meet their financial needs based on a particular criterion can access some services of the Social Welfare Board. In discussing how services provided by the Council and Boards are formulated (i.e., meanstested or more akin to a rights based model), a member of the leadership provided the following analysis.

I'm not sure I would agree with that [i.e., programs are means-tested]. I think we do have [a] full [range]; for example, we've got [...] programs where people of all stripes will access. [...] It might not be a financial need, but there are other social needs that they might have [...]. I think that is access by a broad group of people. [...] Poverty [is] defined by multiple metric elements, $[\ldots]$ and $[\ldots]$ based on these broad parameters not just income. I would agree some of our programs are very [targeted] because we are trying to drive a certain desired outcome, and that is to get people out of the different layers that exist in poverty. [...] (interview 6)

The role that needs assessment played in determining what the key areas of focus should be for Boards as well as the Council resulted in a range of responses. Several 
Board Chairs pointed to not being able to conduct surveys or capture concrete data relevant for determining the necessary programs and services. This will further be explored in the challenges section. A member of the CFC executive noted that needs analysis comes into play when the Imam appoints the new leadership, and a strategy for programs is recommended (interview 6). The needs of the community were described as being assessed through previous program experience, focus groups or specific interactions with members of the community. These were seen as inputs that provided information to develop a comprehensive understanding of community needs (interview 6).

There has been a more recent push to consolidate the functions of the various Boards and have an underpinning of quality of life in each of the Boards and portfolios. It is also important to note that each Board in the Constitution was created with a specific mandate, and this to some extent has informed the rationale of the various Boards.

The Social Welfare Board is described as foremost being focused on empowering individuals and families to increase their quality of life and to mitigate distress of a specific segment of the Ismaili population (interview 15). As well, the importance of individuals not feeling isolated was highlighted. The role of the Social Welfare Board was explained by one Chair as being the core of the community with concentric circles of Health, Education, Economic Planning, Women's development and Youth Boards supporting that core, and the Council for Canada encompassing these circles. This was then seen to extend to the broader society and then internationally (interview 15). The services of the Social Welfare Board encompass social support services, self-reliance and the quality of life programs as well preventative services (i.e., workshops and seminars 
on various topics). In addition, external relationships are maintained to allow for referral to other services.

A Settlement portfolio, which is unique to the Council in Canada, is tasked with assisting members of the Jamat that are new to the country. It provides assistance on various aspects including initial basic needs (housing, health card, etc.), adaptation (education regarding norms, values, laws, rights) leadership development (e.g., involvement in community institutions) and integration (contribution and involvement in society at large) (interview 11). Individuals that utilize the services of the Settlement Portfolio are assessed and tracked based on variables such as home ownership, university entrance, and the like.

The focus of the Education Board is supporting excellence at all levels of education. The interest of the Imam in early childhood development is encouraging the Board to examine a model that would be of value to the Jamat as a supplement to what is already available. The Board is also responsible for administering scholarships that are available to the Jamat for post-secondary education (half scholarship/half loan funded by His Highness) and loans for vocational studies. The Board keeps informed regarding university attendance and more recently is looking at completion of high school for the newer segments of the Jamat (previously this area was not examined as there tended to be a high level of university entrance). Additional services such as language and tutorial services are also under the purview of the Education Board (interview 12).

The Economic Planning Board's mandate includes the economic status of the Jamat, providing relevant economic information, looking at potential in industries, promoting savings, and formalized mutual assistance. The key areas include skills and 
employment, identifying viable career options and assisting families earning $\$ 40,000$ a year or less. There are also initiatives for members of the community wanting to start businesses like micro-enterprise loans and seminars that promote financial literacy. As well, the Board encourages the Ismaili Business Professional Association as a means to promote entrepreneurship, networking and for creating potential business alliances (interview 13). It was noted that overall homeownership does not seem to be an issue as many Ismailis own their homes and renting is usually by choice (ibid.).

The Health Board's mandate is to improve the quality of life of the Jamat in the area of health. The focus is on trying to help optimize health and well-being to improve quality of life, which also includes mental health. The key areas outlined included: access to diagnosis and treatment, prevention in the areas of mental health, physical and chronic diseases, issues of public safety and injury prevention and international strategic support to the Aga Khan Health Services and the Aga Khan Foundation. It was noted that in Canada, the Health Board is not providing the provision of health care, but it is assisting individuals to understand what they may be facing and helping to advocate and navigate within the system (interview 9). As well, the Board addresses issues of distress such as potential family violence and more recently issues related to post conflict such as posttraumatic stress disorder. The area of mental health was identified as still being linked to stigma and as such an effort is being made to enhance openness, for example, pilot projects were being conducted in British Columbia and Edmonton (interview 9).

The Youth and Sports Board mandate was identified as focusing on issues that are relevant to the youth of the Jamat. The youth was broadly defined to include young professionals. Key areas for the Board include social and health issues like active living 
and issues of identity. The goal is to create and implement programs (e.g., summer programs that combine life skills and social skills) that focus on various aspects of development and are relevant to youth in their everyday challenges (interview 14).

The Women's Development Portfolio and Poverty was described as being focused on the Afghan Jamat. As well, it was noted that five local Chairs are from the Afghan Jamat which was seen an asset for program implementation. There are mentoring programs (e.g., Ismaili Women Economic Development Program) that provide individuals the opportunity to determine their aspirations (e.g., language skills, enhancement of career opportunities), and then work with mentors to help achieve the set goals. There are also preventative programs and programs for teens. The impact global issues may have on members of the Jamat was another area of consideration. For example, women from underdeveloped countries may be facing issues and barriers that continue in Canada (interview 10).

The role of the Grants and Review Board is to audit and review programs and services of the various Boards and portfolios. The reviews are structured more as a dialogue. This ensures that the context for decisions is understood (e.g., a voluntary organization and human resource issues). As such, there is an opportunity to engage with the Boards before information is submitted to the Secretariat in Aiglemont. However, the independence of the Board was stressed (interview 8). The audit information is consolidated at the Imamat level, and this allows for consistency and understanding of the global Jamati needs (ibid.). A member of the CFC leadership noted the importance of the GRB's role by describing it as the organization's "sober second thought", and providing 
an objective perspective for the financial, management and programmatic side of the organization (interview 6).

The Conciliation and Arbitration Board (CAB) established in 1986 is focused on dispute resolution, including international, family, commercial and estate matters. Previously, a tribunal system was in place. However, any dissatisfaction or potential disputes of community members with the Council or the Boards cannot be addressed at any level of $\mathrm{CAB}$, as there is no jurisdiction to do so. The focus of $\mathrm{CAB}$ is described as maintaining harmony within the community, and it is carried out in a manner that is constructive, equitable and voluntary (interview 16). There is a National CAB and five regional $\mathrm{CAB}$ 's where most of disputes are addressed. There is also an international CAB that serves as a level of appeal similar to judicial review within a court system. There is a case management system and at the core is ensuring the "law of the land" is followed (ibid). The CAB is not a part of the Council. It reports directly to the Imamat level. Nonetheless, there is a connection as $\mathrm{CAB}$ does provide feedback to the various Boards like the Social Welfare Board and the Economic Planning Board that may help guide programmatic activities as well as referring individuals with their consent to relevant Boards (interview 16).

In 2004, a review panel appointed by the Government of Ontario led by Marion Boyd was formed to examine the role and impact of the use of private arbitration on potential vulnerable groups. This was particularly in response to a backlash at the time to the idea that interpretations of sharia law would attempt to supersede the law of Canada and in turn result in vulnerabilities, especially for women. The report included a submission by the Ismaili National Conciliation and Arbitration Board for Canada, which 
outlined the history, mandate, organizational structure, processes and safeguards of conciliation and arbitration within the Ismaili community. The report pointed to the comprehensive nature of the $\mathrm{CAB}$ and appended the rules for conciliation proceeding within the report. The report culminated in a number of recommendations revolving around adequate training, addressing issues of power imbalances and screening for domestic violence among others (Boyd, 2004).

\section{Funding for Jamati programs}

The funding for programs and services of the Council and Boards comes from Jamat donations. However, one interviewee noted that there was a time when programs were funded by the Imam. However, as the Jamat became more financially stable they were allowed to participate in Jamati funds for programs (interview 5). As well, it was noted that the funding for the administration of the Council and Boards is still provided by the Imamat level, and the Imam has the discretion to participate in any programmatic funding as deemed appropriate (ibid.). In addition, there is a distinction between funding for programs and services of the Council and any religious dues (interview 6). The budget was described as a "zero based budget" whereby the need for programs is assessed, and then the capacity to deliver programs is determined. Thereafter, the necessary funding is sought (interview 5). The core funding for programs is done at the Jamati level, but the need to look at other potential sources of funding was noted. For example, the potential of accessing funds from other civil society organizations or if the funds are available, the capacity to utilize services already provided was expressed. 
Although the government was not a source of funding, the possibility of determining where government links could be relevant was seen as needing consideration (interview $6)$.

\section{Links with Councils regionally and internationally}

The links between Councils regionally and internationally is more ad hoc in nature rather than there being a strong push for a regional approach or creating strong international links that may help leverage the resources and the knowledge base of the Ismaili community. There are new initiatives such as the Time and Knowledge Nazrana (TKN) that may help with sharing best practices and professionals volunteering in various countries, but it is still in its infancy to be able to make any concrete assessment. There are individual Boards that reach out to their counterparts in the US or UK on an as needed basis in areas such as early childhood development, poverty, youth issues, and the potential for sharing Canadian resources in advancing programs internationally was noted. However, the need to engage more in sharing knowledge and ideas in a systematic manner was highlighted by several interviewees. Other interviewees pointed to the Leaders International Forum (LIF) as a way to share information and create potential links. The LIF was described as a consultative body where Presidents of the various Councils meet, and it was seen as a potential site for collaboration (interview 6).

\section{Ismaili Community Links with Government and External}

The engagement with the state on issues related to migration was important at two points in the history of Ismailis in Canada. As discussed, after the expulsion of Ismailis from Uganda, the Aga Khan negotiated the settlement of his community in Canada. The second key period was during the upheaval in Afghanistan. In this case, the Council for 
Canada (now well established) signed the necessary protocols for Ismailis from

Afghanistan to come to Canada. The Council was able to provide support (skills training, language etc.) and assistance with "integration" into Canadian society. FOCUS Canada provided the role of guarantor (interview 5). The initial protocols were signed in September 1992, and further protocols were made between 1994-2001. As described by one member of the CFC leadership:

I don't know the history around the 1992 agreement, [but it] is exciting in that we had helped the relationship between the government and the need that we had. [...] I would say the leadership has good relationships with government, and I would treat AKF as part of that of that leadership [...]. A specific relationship that AKF could call on and would be very open to sharing [...]. If it's best to leverage government, we would try to do that, and frankly the government really is going to do [the] best for them too. $[\ldots]$ in the case of immigration, it only made sense to work with the government $[\ldots]$. (interview 6 )

Engagement with the Federal government is concentrated at the National Council level and is coordinated with AKFC while the Councils based in a particular province deal with the provincial government under the guidance of the National Council and any municipal issues are managed at the local level (interview 4, 5). However, there are some Boards such as Education and Health that would on occasion connect directly with government or external partners. For example, even though there is no specific Memorandum of Understanding in place, the Education Board may connect with the Ministry of Education or school boards directly (interview 12). As well, the Health Board has links with the Canadian Mental Health Association for a pilot program and there is also a possible program with Health Canada and the CHAMP program at the University of Calgary in cardiovascular health. The various Boards also have external connections with NGO's, academia and other professionals for various workshops and speakers 
series. The CFC also has a dedicated Communications portfolio that manages external relationships, and this allows for a coordinated effort. The need to strengthen external relationships and re-examine potential duplication was also noted. As stated by one Board Chair, the capacity to have services in conjunction with other external agencies was limited because it required building sustained relationships, and this was seen as difficult because the Boards are voluntary and operate predominately on weekends and evenings (interview 13). As well, the issue of managing potential relationships was seen by this Chair as a structural problem because there was a hesitancy on the part of the National Council to create reciprocal relationships, and was described as being "insular" in its engagement (interview 13). Another Chair pointed to the differences in regional capacity to foster relationships and noted the importance of having the right people in the roles to manage relationships (interview 10).

The connection to government and fostering external relationships is to some extent connected to being able to serve the needs of the Ismaili community, so they can meet the needs of broader society. This idea is articulated in the Constitution and is explained by a member of the CFC executive as one where there is an attempt to first ensure that the circle within the community is strong and there are "no weak links" (interview 6). This was seen as important for the Ismaili community and in providing the strength and ability to contribute to the broader society. Also, an external relations program that focused on civil society organizations with similar areas of interest such as poverty eradication, economic enhancement, and youth development was seen as a way to contribute to the broader society. 
As well, there is engagement of different Boards and the Ismaili Volunteer Corps in various external relationships, including sharing knowledge with Immigrant Women's associations, holding conferences on relevant topics open to the general public and joint programs with the YWCA. There are also civic engagement and leadership programs that create opportunities for Ismaili youth to serve the broader external community, for example, during the Olympics in Vancouver, and with the United Way and Habitat for Humanity (interview 14).

\section{Challenges}

The various Board Chairs and members of leadership highlighted several areas that were overall challenges or specifically related to their individual Boards. Some areas highlighted were the pressures of limited resources, being a voluntary organization and trying to deliver services for issues that are complex and multi-dimensional and that are expected to be on par with more formal agencies. This brought to the forefront issues of consistency and the capacity to deliver services to meet the Jamat's expectation. As described by one Board Chair, because the Council and Board programs and services are connected to the tenets of the faith and the link with the Imam, there can be a hesitancy to discontinue programs which can in turn create a dependency rather than sourcing external programs (interview 13). As well, the difficulty of trying to provide a high level of service in the evenings and weekends was noted. Furthermore, the differences in expectations and outcomes were highlighted. One Chair noted," [we] are not creating the outcomes Council and GRB think we are. There is a disconnect between intake and expected outcomes" (interview 13). Another perspective suggested that perhaps there 
was a need to further enhance the professional capacity and institutional framework to address issues facing community members (interview 15).

Another area related to the organizational structure was the connection to the

Jamat itself. As described by one member of the leadership:

It is generally working well. I think in [the] areas of improvement like any other matrix organization [is] getting agreements on outcome measures. Who is responsible for what outcomes, and what [are the] delivery outputs. $[\ldots]$ if there is an area of improvement required, it would be around ensuring that the volunteers involved have a full picture of what the needs analysis is, and as a result, what the outcomes ought to be. So I'm not working in silos, but [I'm] working with an understanding of a full map and not just my area or my region of that map. (interview 6)

Other issues highlighted included lack of program awareness within the Jamat, not respecting the time of program providers (e.g., leaving early, coming late etc.), having competing interests both internally and externally, and for some individuals struggling with day-to-day issues of survival making committing to programs and services difficult. As well, the need to harness the capacity within the Jamat and engage a broader segment in achieving results was noted as becoming more relevant (interview 6). It was suggested that previously there was a tendency for those appointed to the various Boards and committees to take full responsibility for programs and results, but there is a need for more community responsibility for the delivery and outcomes of programs and services within the Jamat (interview 6).

The willingness to access services and issues of stigma was also discussed. Programs such as those offered by the Social Welfare Board are specific to members of the Ismaili community with a certain level of income and are targeted. However, one Board Chair noted that the previous segmented approach was more apt to stigmatize individuals than the more thematic approach (interview 15). As well, it was noted that 
there has been a significant effort to ensure confidentiality and engender trust when individuals seek assistance, and the professionalization of services was seen as helping to diminish issues of stigma (interview 6). The importance of ensuring that individuals did not feel stigmatized or resistant to seek assistance was seen as a legal and moral obligation (ibid.). Although issues of stigma were addressed, it was seen as an ongoing effort and difficult to overcome.

The level of understanding that the Council and leadership had of issues facing the Jamat so that relevant programs and services could be provided was linked to needs assessment or lack thereof. Several Chairs noted that the tools necessary to conduct comprehensive needs assessment were not available. As well, some interviewees noted that data retention was not permitted. However, one Chair pointed to aligning with the Settlement Portfolio and the Social Welfare Board to gain relevant information (interview 12). Some Chairs pointed to using focus groups or other qualitative data sources as a means of gathering necessary information. The change in Board leadership and members every three years brought issues of continuity to the forefront when information is gathered more on an informal basis (interview 13).

Challenges related to how services were delivered and the need to take into account issues of language, culture and potential gender differences in new segments of the Jamat were also noted (interview 9).

The adequacy of the composition of the Council and Boards, addressing the crosssection of needs within the Jamat as well as the level of collaboration with the Jamat garnered various responses. One member of the CFC executive noted that without collaboration there will be inefficiencies, and this can create frustrations within the 
community. He noted that this has happened in the past, and there is a realization that the leadership cannot act on its own and be "proprietary" (interview 6). Rather, there is a need for outcomes to be agreed on at the outset, so the work within the community can be done in a coordinated manner (interview 6). There was recognition of potential socioeconomic and education differences within the community being barriers to participating in leadership positions. However, education level was not seen as limited to formal education and could include life experience and competency. This provided a level of flexibility when choosing leadership. The issue of socio-economic status was seen as more difficult to address because individuals themselves may see it as an area that might be stigmatized and be unwilling to engage. It was suggested that an effort is made to ensure a level playing field, so that no one is left out because of a potential barrier (ibid.).

One Chair noted that the structure is very executive focused, and sometimes decisions are made prematurely without necessarily having the required information. As well, it was noted that the culture is still akin to a "boys club", and there was a need to be more democratic than patriarchal in structure as well as encouraging more of a work-life balance (interview 10). It was suggested that the current culture could potentially lose young talent and women. As well, the input of the Afghan Jamat was seen as important in decision-making (ibid.). Also, ensuring the right individuals were engaged, and the need to keep individuals motivated was highlighted (interview 10). Another Chair noted the importance of staying in touch with the Jamat, and the executive needing to "have the pulse of what is happening on the front lines" (interview 13). The importance of diversity in terms of youth and the Afghan Jamat as well as the need to devote the necessary time to training and development was expressed (ibid.). The issue of diversity was echoed by 
another Chair noting that there is not enough plurality, but acknowledged that it is getting better (interview 11).

Several Board Chairs noted the potential for non-alignment between National leadership and Board Chairs as well as between the national, regional, and local levels. One Chair noted that the roles and responsibilities are not clearly defined. It was sometimes not clear whether the Council President or Board Chair was responsible for the mandate (interview 13). As well, it was suggested that the Council did not have a leadership culture that had an effective enforcement mechanism in place. This made it difficult to ensure alignment and follow-through (interview 13). As well, it was indicated that some individuals see their responsibility as to the Imam rather than reporting to the Council executive, making ensuring accountability difficult (interview 13). The institutional structure itself was noted as a potential source of non-alignment. This is because the various Boards are rooted in implementing their individual mandates, and an integrated approach did not occur naturally (interview 4). Another interviewee expressed that because the National Council is responsible for the strategic thinking and the local level is responsible for implementation, there can sometimes be a disconnect in terms of the types of programs and services that are needed (interview 10). As such, it was suggested that there is a need for more grassroots consultation to understand the needs of beneficiaries and ask how support can be provided by Council and the Boards (interview 10). The mandate of the Council was seen as needing to flow from the bottom-up rather than being top-down. As stated: "we should not be making mandates up, if they do not relate in any way to their quality of life" (interview 10). 


\section{AKDN/AKFC and the Ismaili Community Link}

The link between AKDN and the Ismaili community generally and the relationship between Aga Khan Foundation Canada (AKFC) specifically is described from the perspective of an individual within the AKFC leadership as one of dependency and support. Also, according to this individual the linking of the work of AKDN to Imamat institutions creates a connection to the Imam and willingness to support his efforts as well as creating a space for the Ismaili Jamat to exercise their ethical framework. In addition, the link between the Ismaili community's ethic of volunteerism and willingness to engage in AKDN/AKFC projects was also highlighted. The AKFC interviewee stated that:

There is a great amount of partnering or dependency that the AKDN actually has with the Ismaili community. The Ismaili community is a contributor of not only material resources but also a lot of the intellectual and the financial resources. [...] The motivation from the Ismaili community's point of view is probably three fold. One [is] that they want to be supportive of the Institutions of the Imamat because they know how important it is to the Imamat that these Institutions succeed. [...] The second aspect of it is an avenue through which they actively participate, not everyone is going to end up working in the AKDN, but I think everybody has an opportunity to get involved in this endeavour, and they do that by financial and volunteer contributions. [...] The third thing is that it is a great avenue for the Ismaili community $[. .$.$] to exercise their own$ sort of ethical framework [...]. (interview 2)

There is coordination between AKFC and the National Council to ensure that any potential senior appointments for the organization are not already engaged in volunteer capacities within the community. The Ismaili community is also a targeted annually as a source of funding for the AKFC, and this is coordinated with the Council to ensure that it does not conflict with any fundraising by the Council for the community 
level programs and services (interview 2). As well, Ismaili volunteers are seen as an important link to reach out to the broader Canadian population about the work of the AKDN. The volunteer ethic within the Ismaili community was seen as coming into play in a large way within AKDN. These volunteer roles included positions within the governance bodies of AKDN, non-remunerated full-time positions, and other volunteer roles. This voluntary service was seen as being vital to the Network and was connected to the long tradition of Ismailis contributing to community institutions (interview 3).

The ethic of volunteerism was seen as an important facet of all programs, and it went beyond the engagement of the Ismaili community. It was connected to the idea of self-reliance and independence. Thus, a component of the volunteer ethic was described by a member of AKFC leadership as, "[...] providing a vehicle to express agency. To allow people to be actively involved in self-help, [and] to be able to take control of the development process which they are engaged, so that you are never in a position of feeling subordinated and a victim to forces you don't control [...]”' (interview 3).

The formal link between AKDN in Canada and the Ismaili community is forged by having the National Council President sit as an ex-officio member of the AKFC Board (interview 3). However, the ultimate level of coordination was identified at the Imamat level. It was stated by an individual within AKFC leadership that "the ultimate coordination happens at the level of the Imamat because $[. .$.$] the Imamat is managing$ many different activities, and these are all activities that ultimately have the patronage and sponsorship of and ultimately [are] led by the Imam himself" (interview 3).

When the leadership and Board Chairs of the Ismaili community were interviewed regarding the connection with AKFC, the various activities of mobilization 
within the Jamat in terms of fundraising campaigns and coordinating volunteers for AKFC were highlighted (interview 5). As well, it was noted that the Council and AKFC coordinate when it comes to government relationships because AKFC already has strong relationships with government due to its work, and there is no need for the Council to try and recreate these relationships (interview 6). As such, a member of the National Council executive noted that AKFC and the National Council would "think through broad strategies for the country together" and that "there is a very strong level of collaboration that occurs among institutions" (interview 6).

Also, FOCUS Canada, an AKDN affiliate, was noted as a point of contact for issues related to displaced populations (interview 5, interview 11). There are also informal connections with various Boards and components of AKDN (e.g., the Health Board and AKU and AKHS).

In examining the adequacy of connections between AKFC, the Council and Boards, one Board Chair noted that the connection is high and simultaneously not enough. This was attributed to the number of issues the community level was trying to manage that could benefit from the expertise of AKFC (interview 15). The need to systematically leverage research and best practices not only from AKFC but also from worldwide AKDN entities (e.g., AKF Pakistan poverty experts) was deemed important (interview 10). Another potential area for sharing information was related to of micro-finance (interview 13). This is an area where AKF has long-term expertise. Another area noted was the need to strengthen links with AKU and AKF in the area of early childhood education because of their emphasis in this area and the connection to the work of the late Dr. Fraser Mustard, a worldwide expert in the field and AKU Board Trustee (interview 
12). Despite the potential for more collaboration between the Ismaili community and AKFC and the broader AKDN, one Board Chair noted there has to be a commonality before you can collaborate. It was suggested that the mandate of AKFC was focused on alleviating poverty in developing countries rather than targeting the needs of members of the Ismaili community within Canada (interview 13).

\section{AKDN/AKF in Canada}

\section{Structure}

The structure of the overall AKDN with an emphasis on AKF was described by AKF leadership in Canada. In addition, the importance of the office of the Imamat and having a progeny to embody that office with a focus on the long-term and a mandate rooted in an obligation to engage with issues of overall welfare that is not limited to the Ismaili community was discussed. This idea of an office of the Imam was explained by an individual within AKFC leadership as follows:

I think what's working well is the fact that unlike any other organization that I know of [...] the leader of the Network is not an individual but an office. The leader of the Network is the Imam, and there is always going to be an Imam, and there [has] always been. So as long as there is always going to be an Imam, there is always going to be an Imamat. [...] the fact that the Imamat is an everlasting and ever living institution, I think the consistency $[\ldots]$ continues to be there $[. .$.$] there is never ever a grey [area]$ as to what needs to get done [...]. The vision continues to evolve and develop and move forward which is a great thing. (interview 2)

The focus on long-term time horizons was also connected to the development process itself. For example, it was noted by an individual within the AKFC leadership, "[...] the premise is that if the development process itself is complex and is going to take some time to achieve, then we have to be able to take a long-time horizon" [...] (interview 
3). Furthermore, it was noted by the interviewee that in most places where AKDN operates the goal is to "build and nurture strong institutional capacity [...]" and this type of engagement "would never have a sunset" (interview 3).

His Highness's chairing the overall Board of AKF and the AKDN Committee was seen as providing a level of consistency, and it serves to highlight the central role played by him in setting the vision and ultimately determining how the pieces of the Network interconnect. The Imamat level in some ways was described as having a birds-eye view of the Network. Therefore, it could encourage collaboration and thinking in a multi-input perspective. This was explained by a senior member of the management team at AKFC when providing an overview of how the components of AKDN have sector specializations, but simultaneously the components can come together to provide comprehensive long-term processes for change in the developing world. In addition, it was noted "the Imamat involvement at the Apex of the structure is a significant force of bringing things together" (interview 3).

The overall AKDN Committee and the AKF Board were responsible for developing the agenda for $\mathrm{AKF}$ and $\mathrm{AKDN}$ worldwide. A senior member of AKFC described the governance structure of AKF units and the relationship to the broader Network as follows:

There is a common Board that $\mathrm{HH}$ chairs [...] that presides over all the AKF units. [...] he $[\mathrm{HH}]$ is that Board basically. [...] Each AKF unit has got its own National Committee which is appointed by the Board to oversee and support the work of that particular country unit. So we in Canada have a National Committee that is appointed for a three-year period usually, and they have a direct reporting structure right into the Board. [...] our CEO reports into the National committee, and so they govern and provide us with guidance we need, and in turn they report directly into the National rather the AKF Board. [...] There is one unit that 
is always a coordinating body, so AKF Geneva for us is a coordinating body. [...] They basically have a core team of finance people, of program professionals for each of the thematic areas that we work in, so for education, rural development, health, and for civil society strengthening. [...] [The] AKDN level also has a committee that oversees all of the AKDN agencies, so at the AKDN level there might also be some thinking around what to do in conjunction [with AKF] (interview 2).

As well, the coordination that takes place between AKF units and other AKDN agencies was further described by another member of the AKFC management team.

The $[\mathrm{AKF}]$ units are always in touch with each other at a CEO level. At the level of the rest of the staff, there is a very dense network of relationships that keeps [...] information flowing and coordination occurring and decisions being made. And I would say that is very similar to AKF vis-à-vis the rest of the Network which is to say that AKF tends to have a responsibility for mobilizing resources for many other agencies in the Network, as well. [...] We are in constant communication about needs, about agendas, what resources can we mobilize financially, [...] but not only financially, human resources, technical resources, [and] intellectual resources [...]. (interview 3 )

It was acknowledged that there will always be a need to hone the capacity to collaborate, but it also depends on the specific context. As stated, "the idea of coordination and inter-agency collaboration is an ongoing process of ever refining our ability to orchestrate the right set and integration of inputs given the situation that we are facing which are highly diverse" (interview 3 ). In the context of AKF's worldwide, having a country level presence as well as AKF in Geneva as a coordinating body provided both a ground level perspective and a global perspective. This was seen as providing a level of coherence and enhancing implementation capabilities because AKF in a particular country can draw on its own field knowledge, the capacities of other AKDN entities, and benefit from a global perspective (interview 2). 
There are several sources of funding for AKF in Canada. Administration costs for AKFC are provided by His Highness. It was stated that His Highness " [...] funds all [... administration costs because he has a strong belief that donor funding should not be used for administration purposes" (interview 2). In addition, he may choose to fund specific programs if funding is unavailable from other sources. Donor agencies such as CIDA and more recently private foundations (i.e., MasterCard Foundation) provide funds. There are also two key fundraising events (the World Partnership Walk and the World Partnership Golf events) that create awareness of AKFC programs and garner donations (interview 2).

The continued importance of the Jamat and increasingly individuals outside the Jamat in providing funding for projects was articulated. For example, a substantial donation from a group of Canadians outside the Jamat for the Institute for Educational Development in East Africa was secured, and there was an expectation of similar trends in the future regarding where funding is received (interview 3).

Table 4-4 Summary of Key AKDN and non-AKDN entities in Canada

\begin{tabular}{|l|l|}
\hline $\begin{array}{l}\text { Aga Khan Foundation Canada } \\
\text { (AKFC) }\end{array}$ & $\begin{array}{l}\text { Engaged in international development } \\
\text { program initiatives. The focus is } \\
\text { fundraising, increasing awareness of } \\
\text { development issues, and program } \\
\text { engagement with other AKDN entities. }\end{array}$ \\
\hline AKFED entities & $\begin{array}{l}\text { There is a limited AKFED presence in } \\
\text { Canada, which includes Industrial } \\
\text { Promotion Services, Acorn Packaging Ltd, } \\
\text { and three automobile dealerships. }\end{array}$ \\
\hline Delegation of the Ismaili Imamat & $\begin{array}{l}\text { A space for dialogue and engagement on } \\
\text { issues of relevance to overall development. }\end{array}$ \\
\hline Global Centre for Pluralism (GCP) & $\begin{array}{l}\text { Initiative of the Aga Khan and founding } \\
\text { partner the Government of Canada. The } \\
\text { focus is on research and dissemination of } \\
\text { information related to diverse societies. }\end{array}$ \\
\hline Aga Khan Museum & $\begin{array}{l}\text { Located in Toronto, the Museum will focus } \\
\text { on the preservation of Muslim art and } \\
\text { culture. }\end{array}$ \\
\hline
\end{tabular}




\section{Role of the Imamat / AKDN as a Buffer/ Force-Field}

As discussed, the Aga Khan has been central to ensuring the assistance of Ismailis during times of crisis. The involvement of the Imamat level and in turn the AKDN to create a level of security for Ismailis is linked to the Imam's stated responsibility for the security and welfare of his community. More recently, the Delegation of the Ismaili Imamat (DII), the partnership with the Government of Canada in the Global Centre for Pluralism $^{17}$ (GCP) as well as the upcoming Aga Khan Museum in Toronto are symbols for creating visible links and concrete demonstrations of the Imamat's contributions to Canadian society. In a sense, it cements the idea that the Ismaili community is a selfreliant group, and it is engaged in enhancing Canadian society by participating as active members. As well, there are mutually reinforcing aspects of engagement. The Imamat level can articulate its contribution to Canada, and the Government of Canada can demonstrate its engagement in issues of pluralism and diversity. Hence, we see an articulation of the Imamat level as a kind of intermediary role. These endeavours were described by the Aga Khan at the foundation laying ceremony of the Delegation of the Ismaili Imamat as follows:

The Delegation of the Ismaili Imamat in the federal capital, the new Aga Khan Museum and the Ismaili Centre to be built in Toronto, are symbols of this seriousness and respect that Canada, leading the West generally, accords to the world of Islam, of which the Ismaili Community, though a diverse minority itself, is fully representative. May this mutual

\footnotetext{
${ }^{17}$ The Global Centre for Pluralism (GCP) is described as an initiative of His Highness the Aga Khan in partnership with the Government of Canada. The federal government committed \$30 million with the Ismaili Imamat contributing \$10 million and \$20 million for the Centre's building renovations (the old War Museum in Ottawa). GCP will report bi-annually to the Government of Canada to account for public funds. The Members are as follows: The Ismaili Imamat, Aga Khan Trust for Culture, AKFC, the Government of Canada (2 representatives), Association of Universities and Colleges of Canada, and the International Development Research Centre. <http://www.pluralism.ca/faqs.html>
} 
understanding, so important to the future stability and progress of our world, flourish many fold. It is my sincere hope that, by its presence and the functions it fulfils, the Delegation of the Ismaili Imamat will be an illuminating landmark on "the Mile of History". An epitome of friendship to one and all, it will radiate Islam's precepts of one humanity, the dignity of man, and the nobility of joint striving in deeds of goodness. (AKDN, 2007h)

There is also a sense that projects such as DII and GCP can be a buffer for the Ismaili community should potential tensions arise. The Ismaili community is a small portion of the Muslim community, so these types of links with government may serve as a type of offensive engagement and in some countries as a means for survival while in other countries perhaps as a way to maintain the status quo. For example, the links with government may provide a buffer to recent Ismaili immigrants in the context of changing immigration policies in Canada and the introduction of greater restrictions.

This idea is difficult to tease out, but senior members of AKFC as well as the Council leadership did provide their assessment of the potential of AKDN or the Imamat level being a buffer for the Ismaili community. A member of AKFC leadership stated the following:

The capacity of the Network to earn the confidence and trust of the government in the countries in which we are working through high quality work and transparence about our commitment to national development is important. And does it protect the populations with which we are working. I think it does. Whether it be members of the Jamat or even outside the Jamat, I think it does provide a little bit of a comfort that the government should never feel that the activities of the Network are obtuse or somehow not consistent with the national the development of the country itself. [...] I think more importantly than even that frankly is that there are certain benefits from the formalization of these agreements and relationships because what we are interested in is institutional relationships not just personal relationships. [...]. (interview 3 ) 
A member of the CFC executive provided his understanding of the Imamat level aligning specific objectives in formal relationships with governments. However, he noted the importance of self-reliance and thus judiciously engaging with government when there is a benefit for both the community level and the government. He provided the following assessment.

We don't want to be at the doorstep for every single ask or request. [...] We have a culture of self-reliance, and that culture is deep in our community [...]. However, there are things that the government can help promote. [...] if there was a strategic advantage for us, but also a strategic advantage for government. [...] We can create a win-win. (interview 6)

Furthermore, entities such as the Delegation of the Ismaili Imamat and the Global Centre for Pluralism provide concrete structures that reinforce a state-like logic of the Ismaili Imamat.

\section{Engagement of Government and NGO/Third Sector in Canada}

The history and engagement of government and the NGO/third sector in Canada has been analyzed in other studies (see Laforest, 2011; Graefe, 2004; Phillips \& Levasseur, 2004; Phillips \& Orsini, 2002; Hall \& Reed, 1998). The focus of this dissertation is putting the locus of analysis on the Ismaili Imamat, AKDN, and the Ismaili community institutions and from that anchor exploring the relationship with government. Nonetheless, a brief overview for the reader of the relationship between the NGO/third sector and the government in delivery of social services will be useful. According to Laforest, starting in the 1990s there began a more systematic government shifting of social service delivery to non-government actors, although what role this sector would play in agenda setting and policy making was unclear $(2011, \mathrm{p} .1)$. The focus on 
efficiency, cost-cutting and accountability culminated in ideas of New Public Management and contracting services to the private and third sector (Aucoin, 1995; see also Phillips \& Levasseur, 2004; Phillips \& Orsini, 2002). This created a particular dynamic of state as auditor in its relationship with the private sector and NGOs (Phillips \& Levasseur, 2004). However, the extent to which the state can download important welfare functions to the non-profit sector or private sector has also been questioned. As argued by Hall and Reed (1998), "while there is no question that public expenditure must be reduced and re-patterned, we must not forget that the original raison d'etre of our social programs in Canada was enhanced social cohesiveness - a strengthened citizenship based on principles of mutual support, equity and fairness of basic social conditions and universal inclusiveness" (p. 19).

Some key turning points provides a glimpse into the possible scope of engagement and collaboration of the third sector with government in areas of policy. The importance of the Volunteer Sector Initiative (VSI) ${ }^{18}$ in Canada has been pointed to by scholars such as Laforest (2011) and Phillips (2001) as allowing for a shift in the governance relationship between different levels of government in Canada and the third sector. In essence, it has allowed for a comprehensive understanding of how the sector shapes and is shaped by governance relationships (Laforest, 2011, p. 25) rather than being fixated on a state-centric approach to welfare issues. However, shifts in engagement by the federal government with the third sector are important to assess to

\footnotetext{
${ }^{18}$ An endeavour by the Government of Canada and the Volunteer Sector was initiated to address key issues of relevance (200-2005). The areas included the relationship between the Government and the Voluntary Sector; capacity building within the voluntary sector; volunteering initiatives; regulatory issues; involvement of the voluntary sector in policy issues; and understanding how the federal government funds the sector. See < http://www.vsi-isbc.org/eng/about/funding_allocation.cfm>
} 
fully understand how previous initiatives may impact the scope of influence of $\mathrm{NGO} /$ third sector on issues of welfare (ibid.).

The relationship of the Ismaili Imamat, $\mathrm{AKDN} / \mathrm{AKF}$, and the Ismaili community with government in Canada provides an opportunity to understand the engagement of state with a hybrid configuration that may help further tease out government engagement on issues of relevance.

\section{Imamat /AKFC Link with Government and External organizations}

The relationship between AKFC and CIDA is one that has been ongoing for more than 25 years. AKDN's engagement in various sub-Saharan Africa and Asian countries has aligned with the various countries targeted by CIDA. The benefit of having a Network like AKDN is that it has extensive ground level experience and the funding from CIDA is not applied to the administrative costs of the Network. Also, there is a base of Ismaili volunteers and contributions made by the Imamat level that provides more mileage for assistance dollars. The limited budgets of agencies such as CIDA require having partners with a previous track record in countries of interest and are considered legitimate, so-called "honest brokers". For example, Smillie and Hailey (2001) describe AKFC as a "conduit" for CIDA funding to organizations in South Asia (p. 34). Also, high level government links of the Imamat level with the Prime Minister's Office as well as the Minister of International Cooperation and Development facilitates building trust and a level of confidence. The involvement with CIDA has been described as a partnership, although the ground level engagement of CIDA and the capacity for its program officers to visit projects is limited. CIDA concentrates on soliciting Requests 
for Proposals for implementing desired programs. However, AKDN and AKFC do not tend to respond to such requests because they see themselves as the initiators and in some ways the intermediaries between the ground level realities based on their field experience and the sources of funding available. As described by a program officer at AKFC.

One of the mechanisms [...] for Canadian funding [for] development projects through CIDA is an RFP process where an aid organization [...] will put out a call for proposals for a particular project that they want to implement. [...] The AKDN as a whole does not respond to these types of calls for proposals. Our approach is that we launch projects based on demands and needs that we ourselves through our field offices have observed. So what AKFC does is [it] aligns the needs of the field with donor priorities and the Network's priorities. (interview 17)

Unlike in other countries where there are defined agreements of protocol, this is not the case in Canada. As such, there are ongoing negotiations with CIDA regarding programs of interest, and there may be outcomes that are specified by CIDA as a basis for funding (interview 2).

In addition, AKFC provides expertise on foreign policy issues, for example, presenting at Senate meetings regarding the development and security challenges facing Africa (Canada, 2006). AKF/ADKN's long-term engagement in issues of development creates a continued connection to what the government is doing in areas of development. As well, the level of coordination needed in many developing contexts requires a multipronged approach encompassing the community level to high-level national and international relationships. This is seen as vital to the work of AKFC and the overall AKDN. The importance of governments ensuring an enabling environment for private enterprise and development to occur is central to the work of AKDN. In the Canadian 
context, the idea of an enabling environment was connected to the capacity to provide tax receipts for donations that helped fund the initiatives of AKFC (interview 2).

The focus on fostering an enabling environment allows AKDN agencies to engage in for-profit and para-company initiatives with a certain level of confidence. It is also important to note that the Aga Khan has been consistently involved in various programs and services in many developing countries as well as seeking partnership and support in developed countries. This engagement continues even when governments and priorities have changed as different leaders and political parties have come to power.

As discussed in the section on the link between the Ismaili community and AKDN/AKF, there remains a dependency on members of the Ismaili community for volunteer resources and financial contributions for projects in other parts of the world, but there is no delivery of health and education services in Canada. Vulnerabilities at the community level are the responsibility of the Council and Boards, and this may necessitate creating links with government and other external agencies in the areas of welfare. For example, the Council and Boards in Canada are engaged in some links externally and more recently are exploring ways to engage with the state that would be mutually beneficial.

Even if the mandate of AKFC is focused on issues of welfare in countries other than Canada, there are projects of the Imamat in Canada like the DII, GCP, and the Aga Khan Museum that may provide a space for engagement on issues of interest. For example, the DII is positioned as a diplomatic endeavour that may tangentially benefit the Ismaili community in Canada because their Imam is at the helm providing a space for dialogue and engagement on issues such as Muslim heritage and overall development. 
More recently, in October 2012, the Government of Alberta was the first province in Canada to sign an Agreement of Cooperation with the Ismaili Imamat. The aim is to expand collaboration in areas of interest, such as health sciences, education, environment, private-sector, and economic development among others.

Although the work of AKFC is focused on developing countries, the potential for programs in developed countries was explored. There are countries such as Portugal where there is a protocol of agreement in place with the Ismaili Imamat. The focus of engagement is in early childhood education and some small-scale entrepreneurship endeavours. The possibility of AKDN engagement in developed countries was explored with a member of leadership in AKFC. It was noted that the decision would be up to the Board, and it would be necessary to determine how engagement in a particular developed country would bring a set of "comparative advantages." In essence, there would be a need to demonstrate a specific expertise or institutional capacity that is not already being addressed by providers in the particular country (interview 3 ).

Another area of engagement of AKFC is in research. This serves to create broader awareness of development issues, enhances best practice recommendations, and creates a foundation for influence in policy engagement and agenda setting in the areas of interest to AKDN/AKFC. A number of published studies commissioned by AKFC include examining leadership, strategy and management in Asian NGOs (Smillie \& Hailey, 2001), the role of the third sector in shaping the Canadian agenda in international cooperation (Gilles, 1997), and the role of Canadian philanthropic support for international development and relief (Embuldeniya et al., 2002). More recently, the Delegation of the Ismaili Imamat has hosted many events and book launches focusing on areas of 
development. These events draw academic, government personnel, citizens, and those engaged in international development work. Also, as part of CIDA's mandate, funding is provided to AKFC for raising Canadian public awareness of development issues (CIDA, 2012). As well, AKFC has jointly held conferences with CIDA to discuss issues such as philanthropy in developing countries (Raymond, 2004).

\section{Regionalization}

The way in which development is conceptualized tends to be state-centric. For example, states that engage in development like Canada through CIDA continue to focus on a country-to-country approach. However, there is some willingness from CIDA to assess the potential of a regional perspective in its engagement with AKFC. However, the limitations governments may face related to issues of sovereignty and the country level being a suitable planning unit may continue to dictate a country-to-country approach. When asked about the push to a regional approach from an AKDN perspective, a senior member of the AKFC management team provided the following analyses:

[...] there are processes of regionalization already underway in the parts of the world where we are working, and we want to both respond to those processes of regionalization and support them because most these countries we are working with are economically sub-scale, and so the market will be a far more efficient, effective, and profitable if it's thought of in a larger way. Also, there are things that we think that countries can learn from each other in a more systematic way. We also think that it knits countries together in a way [that] ends being a bulwark against conflict in many parts of the world, as well. [...]. (interview 3 ) 
Despite the move to a more regional outlook, it was noted that:

[...] most donor agencies in most parts of the world continue to look at and think about things in country by country [basis]. [...] it still is the most convenient planning unit [...]. [...] at CIDA [you see] some openness to talk about things as regional efforts, and I suspect that is going to intensify over time, but today it's very difficult to develop to access a funding envelope that is dedicated to regional effort. (interview 3 )

\section{Conclusion}

The capacity to tap into the logic of hybridity at the Imamat level allows for components of AKDN i.e., AKF in Canada to engage in a sphere above the community rather than being confined at the community level. As well, the community level is making efforts of push its boundaries. AKFC acts as an intermediary between AKDN/AKF in East Africa and the Government of Canada via CIDA. In addition, AKFC is engaged in providing expertise to the Government on issues related to development. The capacity for a mixed logic also allows engagement with the government in Canada. More recently, AKFC is housed in the Delegation of the Ismaili Imamat building. It is a symbol for negotiating that space above the community level and is positioned to make direct links with the federal government and other embassies.

Recent endeavours such as the Global Centre for Pluralism have representatives of AKFC and representatives from the Government of Canada on the Board. Also, the signing of a recent protocol agreement with the government of Alberta and the Ismaili Imamat will see AKFC take on a facilitation role. However, engagement to the level of co-production of welfare services is not on the horizon, as there would have to be a clear understanding of who the constituency in the Canadian context would be. 
However, so-called co-production at the level in terms of idea generation such as with the Global Centre for Pluralism and focusing on broader issues of Muslim heritage and culture via the Aga Khan Museum may be the ideal locus of engagement. Also, DII engagement in issues of development and acting as a place for "quiet diplomacy" on issues of interest to AKDN may allow for a level of influence on issues of importance to the Imamat. When necessary AKFC can be an intermediary between the government and the Ismaili community, this was demonstrated during the migration of Ismailis from Afghanistan to Canada. However, there is the potential that having the capacity for mutability in logic may create blind-spots to vulnerabilities at the community level. As noted by an interviewee in the AKFC leadership, there is a certain level of confidence of not having to address issues related to the Jamat as issues of welfare are taken to be addressed at the community level (interview 2). However, given the limited financial and volunteer resources at the community level, there may be a need to re-evaluate this assumption. In some ways, there is a disconnect between community needs and the trajectory and scope of what AKDN has become for the broader mandate of the Imam. Thus, there may be a need to re-image the Council structure in its level of participatory engagement with the community itself and simultaneously enhancing its capacity not to be confined at the community level.

The rationale for individuals from the Ismaili community engaging with activities of AKDN/AKFC have been expressed as the opportunity to engage in the work of the Imamat and his broader mandate. Although there are opportunities for collaboration between AKFC and the community, especially in times of crises, the capacity for the community level to tap into the expertise of AKFC/AKDN on issues of relevance is not a 
straightforward proposition. The mandate of AKFC is linked to the Imam's broader mandate rather than members of the Ismaili community living in Canada.

The potential for innovation at the community level is in some ways limited by the lack of comprehensive engagement by the community itself in the direction and scope of programs and services. Nonetheless, the community institutional infrastructure draws attention to the comprehensiveness of services provided and the scope and the foresight regarding the need for themes in understanding issues of social development. However, issues of resources both financial and voluntary at the Council level make addressing issues of the most vulnerable within the community context difficult. As well, framing welfare issues in terms of self-reliance and independence rather than a rights-based perspective can bring to the forefront issues of stigma and the limitations of a dependence on an unpredictable donor based funding mechanism for programs and services. However, the idea of not being confined to the community level when trying to resolve issues of welfare also pushes engagement and the potential for leveraging resources outside the community level (e.g., partnerships at state and other external organizations). This is demonstrated by CFC examining potential links with government and other socalled third sector entities. These links may prove to be more relevant to the needs of the community than perhaps links with AKFC. 


\section{CHAPTER 5: TANZANIA CASE STUDY}

\section{The Ismaili Community in Tanzania}

The history of emigration from India to countries in East Africa date back to A.D. 800 and 1500 , and it continued into the $19^{\text {th }}$ and $20^{\text {th }}$ century (Himbara, 1997, p. 7). Individuals that came from different backgrounds, spoke different languages and were part of different religious groups came to be known homogeneously as "Asians". This served as an easy classification anchor during the colonial period. Although many individuals who emigrated from India severed ties with their country of origin, the category of Asian served to create a separateness from the local African population. According to Himbara (1997) this has limited full engagement in the policy and processes of evolving countries in East Africa. Given the distinct histories and background of the various East African Indian communities, I will not attempt to provide a comparative analysis of the different scope and trajectories of institution building within the various communities. However, as with the Ismaili community, there were institutions in the areas of health and education that were established during colonial periods and institutions continue to varying degrees today (Kaiser, 1996). However, the transnational nature of AKDN entities and the presence of a strong central decisionmaker is a key distinguishing feature. As well, there are formal national protocol agreements in places where the work of AKDN in health, education, and economic development are recognized. 
Ismailis first came to Zanzibar in the mid- $19^{\text {th }}$ century from western India (Walji, 1974). Zanzibar was a thriving trading port, and it provided enhanced economic opportunities for Ismailis (ibid.). For many Ismailis, the decision to migrate to East Africa from India was influenced by the guidance of the Imam, Aga Khan III (Walji, 1974). In India, Ismailis were predominately farmers, and unfavourable agricultural conditions (e.g., drought and famine) increased their willingness to leave India for new economic opportunities (ibid.). Individuals who initially migrated to East Africa were able to provide assistance to family and other community members who migrated after (Walji, 1974). During the early phases decisions regarding who would lead in matters related to the community and the organization of the Jamatkhana were left at the community level (Walji, 1974). This included organizing schools and medical services (Kaiser 1996). For example, a wealthy Ismaili merchant founded the first hospital connected to the Ismaili community in the $19^{\text {th }}$ century (Kaiser, 1996; Ruthven, 2011). As well, a school started in 1899, more akin to one room schoolhouse, focused on literacy skills (Kaiser, 1996). As discussed earlier, a challenge to the authority of Aga Khan III in 1905 served as an impetus to formalize the role of the Imam and his authority over the Ismaili community. This took the form of written rules and regulations for the Ismaili community. As the Ismaili population grew and migration expanded to other parts of East Africa, they began establishing more of a recognizable institutional structure with the Imam overseeing the process. The focus on health, education, and economic development initiatives continued with Aga Khan IV and more comprehensive constitutions were introduced. 
During the colonial period first under the Germans and then the British, the Ismailis in Tanzania were involved in creating community-based structures for education and health as access to services was restricted because of racialized policies. Although the Ismaili community was segmented during the colonial period, there were also aspects of preferential treatment by the British (Nanji, 1974). Walji (1974) describes the Ismaili community position as a "middleman" between the British and the local African population. After there were changes in legislation by British colonial powers, the Ismaili Health and Education systems began opening up their institutions to the broader population (it was the first to do so) (Ruthven, 2011; Kaiser, 1996). However, integration at the social level has not necessarily been the case (Kaiser, 1996).

After colonial rule and during the early phases of independence, during the time of Aga Khan IV, there was increased investment by Ismailis in real estate and business ventures. However, changes to the political ideology in 1967 with the nationalization campaign and its focus on socialism restricted the capacity of Ismailis as well as Aga Khan initiatives (Kaiser, 1996; Nanji, 1974). This created some tension with the government and Aga Khan institutions (Kaiser, 1996). So, when compared to Ismailis in other parts of East Africa, such as Kenya, there are greater differences in socio-economic status. This stifling of growth for a community that engaged with the market to increase its quality of life was a clear limitation. Another factor that affected Ismailis in Tanzania was the expulsion of Ismailis from Uganda in 1972. This period created a heightened level of uncertainty and many Ismailis decided to leave Tanzania as a precautionary measure. 
Today, unlike in Canada where Ismailis have a level of buffer with government welfare mechanisms as well the Council structures, this is not the case in Tanzania. As argued by Temu and Due (2000), "while the inadequacies of Tanzania's former socialist economy have been very clearly demonstrated by the achievements of the reform process, the management of an equitable and effective market economy still requires a key role for the state" (p. 710). The authors emphasize the need for government investment in the areas of health, education and infrastructure (ibid.). The strain on the Ismaili community structures and the limitations of the capacity for community members to donate financial resources for programs and services are of critical concern. Although the formalized AKDN structures in Tanzania have some links with Council, there are still some key vulnerabilities that remain. The key challenges and barriers will be explored in this case study.

\section{Changing Demographics}

The height of the Ismaili population in Tanzania was in the 1960's, and the infrastructure in place in the areas of health, education, and economic development provided a level of stability within the community. It is estimated that before 1971 there were approximately twenty-five thousand Ismailis living in Tanzania, however, by 1995 only about four thousand Ismailis remained (AKHS, T 1991c as citied in Kaiser, 1996, p. 47). At the time of interviews this number has further decreased, but an exact estimation was not stipulated except that the population is quite small. As discussed, the government's nationalization policy (1967) and the instability in neighbouring Uganda in the 1970 's led to Ismaili migration to other parts of East Africa and elsewhere. The sense 
gleaned from some interviewees was that this period was like being in a "holding pattern" both for Ismailis and the Institutions. However, in the early 1990's, there was a change with the signing of an initial agreement of protocol between the Aga Khan and the Government of Tanzania. This resulted in more opportunities for AKDN to work in areas of broader development goals. However, in this case, it was not the needs of the community that were pushing the growth of the AKDN institutions.

Currently, the Council in Tanzania is faced with issues of low socio-economic status within the community. The decreased Ismaili population affects the capacity of the Council to source funds at the community level for programs and services. As well, in some ways the needs of the smaller Ismaili population that were the initial focus of the predecessors to some of the current AKDN institutions are now superseded by the goals of a broader mandate. For example, in the context of the Hospital services, a senior member of the governance structure stated that the initial hospital and medical care centres started within the Ismaili community, but have progressed and "grown up to become the leaders in where they operate, and serve all Tanzanians. Our community has basically shrunk, and our community participation would be less than 0.5 percent now. It is all Tanzanians now" (interview 22).

\section{Previous Studies of Ismailis in Tanzania}

A brief overview of the key studies pertaining to Ismailis in Tanzania will provide an initial jumping off point for the current analysis. Morris (1958) argues that there were several factors that influenced the trajectory of social change for the Ismaili community in East Africa. These factors included the structural position of the Imam as a so-called 
"institutionalized prophet" and his capacity to interpret the faith, the personal history of the Imam with colonial powers, and having a space for Ismailis to be considered a separate group from other colonial structured groups. Bocock (1971) undertook an analysis of the Ismailis in Tanzania based on a Weberian perspective. Thus, an attempt was made to understand the Ismaili community based on understanding the interaction between economic activity and religious ethics.

Nanji (1974) focused his analysis on aspects of modernization and change within the Ismaili community in East Africa. The importance of the Imams as a conduit for change within the Ismaili community, and the need to create a viable social environment as a means to articulate a particular value system was highlighted. Walji (1974) examined the historical developments of the Ismaili community in Tanzania. The engagement in two spheres of an evolving political landscape and the religious connection to the Aga Khan was analyzed. Again, the centrality of the role of Imam as an agent for initiating change within the community was an underlining theme.

Kaiser (1996) provided a comprehensive study of the Aga Khan social initiatives in Tanzania. However, the lens of a transnational corporation to examine AKDN confines the analysis within a particular methodological framework and logic. Nonetheless, it demonstrated the need to understand state-civil society relationships beyond the state level by examining relationships at the international, national, and local levels. KadendeKaiser and Kaiser (1998) examine the notion of identity, citizenship, and transnationalism, and argue that Ismailis in Tanzania have the capacity to simultaneously hold state level citizenship as well as a type of communal citizenship that is not confined 
to a particular state boundary. In effect, this capacity allows for flexibility and acts as a buffer in times of instability.

As will be demonstrated in the Tanzania case, the importance of understanding the centrality of the mandate of the Imam in welfare and the capacity for a logic of hybridity that simultaneously encapsulates aspects of state, market as well as civil society will provide a more complete picture of engagement in welfare production. As well, important shifts in the alignment of the Ismaili community with AKDN's broader mandate will provide a space for understanding vulnerabilities that exist within the Ismaili community context in Tanzania.

\section{Authority of the Imam/His Highness in the Ismaili community and AKDN}

As discussed, the authority of the Imam is central both in the Ismaili community context and within the various components of AKDN. Nonetheless, in the Ismaili context, it was noted that there is dialogue in terms of direction of programs and services (interview 18). However, the dialogue is tempered by the role of the GRB in auditing programs and services and questioning the capacity to meet programmatic initiatives based on the resources of the Jamat. Also, the role Aiglemont (the secretariat of the Imamat) has on influencing decision making at the Council level is closely linked to the budget approval process. As discussed in the Canadian case study, the Imam plays a significant role in the substantive policy direction for the Council and Boards which may temper the capacity to engage with the Imam in a comprehensive manner.

The central role His Highness plays in providing guidance regarding direction as well as the vision for the various programs and services within the context of AKDN was 
reiterated by many interviewees in both the for-profit and non-profit segments of AKDN.

Although the importance of decentralization of decision making at the local Board and management level is emphasized, the centrality of the Imamat level cannot be understated.

This relationship as it pertains to the planning and direction of the Aga Khan Health Services is described by a senior member of the Hospital as one of collaboration that is informed with clear guidance from His Highness.

[...] It is a collaborative process. It is developed by management, but there is a Board, Aigelemont, [and] His Highness. A lot of it has to do with guidance from His Highness. [...] Obviously, it has to be tested with the market, but fortunately we have a vision that is established in some ways. [...] If Mawlana Hazir Imam says I want this institution to be a leader in Health Sciences Education [...] he is not just saying it. There is a huge need for the marketplace. (interview 21)

A senior member of the management team within AKES noted that with any system that is large as AKDN there is the potential to "suffer from over centralization" (interview 25). AKES is part of the Social Welfare Department situated in Aiglemont, and AKES in Tanzania has direct contact with the education team in Aiglemont, but it was pointed out that ultimately "the decisions are taken by $\mathrm{HH}$ [and] based upon his decisions other things flow as to what will happen, what should happen, and how it should happen" (interview 25). Nonetheless, within the context of having a dominant strategic decision-maker, some interviewees highlighted the space available to connect with stakeholders and sometimes work with government to define or re-define a particular policy position. For example, how AKF decides on a particular area of focus and what role His Highness, the Board as well as the various stakeholders play in making those decisions was described in an interview with an AKF executive officer in Tanzania. He indicated that $\mathrm{HH}$ and the Board would have a big picture sense of the key 
development issues in Tanzania and would then engage with AKF to determine what a specific program (e.g., agricultural productivity in Southern Tanzania) may look like and the possible engagement with government and/or the private sector. As well, how a program would fit within the national and local context is considered. Furthermore, it was noted that " $[\ldots]$ there have been often times where AKF has worked closely with government to either define or re-define a particular policy stance on a particular issue $[\ldots] "$ (interview 28).

There are potential barriers to having a pinnacle where the vision and strategic direction is so clearly concentrated. Although many have described that things within AKDN flow based on the guidance and direction of His Highness, a consideration is whether all critical information flows back to him for decision-making. For example, one interviewee, in discussing how information flows within the context of the Hospital, noted a hesitancy to bring critical but relevant information to the attention of the key decision-maker, namely, His Highness (interview 24). This individual, who is part of the academic side of the Hospital, noted that the Hospital in Tanzania is going through a transition, and there are aspects that are not up to par, so there may be a need to refocus attention on standards even if this affects the Hospital's revenue in the short-term (interview 24). Furthermore, in Tanzania there are two bodies involved with the Hospital; namely, the Aga Khan University for the academic component and AKHS for the hospital management part, so there can be differences of agenda, and this could lead to difficulty in working as one cohesive unit. It was noted that the vision from HH may be one that is connected, but there can be different realities at the ground level making it difficult to consolidate (interview 24). Hence, the capacity for that vision and 
understanding to be filtered within the various components of AKDN needs more analysis.

An individual at the helm of the organization who provides the overall vision can allow for consistency, a broader understanding of issues, and bring to the forefront the areas that need coordination. For example, one interviewee in the for-profit sector described the Aga Khan as having a macro view of the various countries and regions (interview 30). He noted that he sends monthly reports for Tanzania to the regional entity, and this is consolidated at the global level. Furthermore, he felt this structure allowed for local issues to be addressed at the local level (interview 30).

There can also be attempts to try and cope with having an unfettered authority at the helm of the overall AKDN, but also seeing a need for greater control at the local level. For example, an individual from the Hospital's senior management team noted the need for mechanisms to allow for faster local decision-making (interview 21). It was suggested that this is also recognized at Aiglemont. However, previously the focus was the Jamat, so there was a different criteria for decision-making. The extent of control at the local level seems to be an ongoing process. This may to some extent be tied up in the evolutionary transition of the health services from a community based to a broader based perspective. As well, for some, the allegiance to and authority of the Imam is still part of the dynamic of the organization.

\section{Structure of the Council and Other bodies}

The structure of the Council in Tanzania is somewhat different from the Canadian context in that the Central agencies of AKDN, e.g., Aga Khan Health Service (AKHS) 
and Aga Khan Education Service (AKES) have Jamati committees that are tasked with looking at the needs of the Jamat and determining how they can be integrated into the thinking of AKHS and AKES. As well, the Chairs of Aga Khan Education and Health Services are ex-officio members of the Council and part of the National Council executive.

Table 5-5 National Council and Boards in Tanzania ${ }^{19}$

\begin{tabular}{|l|l|}
\hline National Council for Tanzania & $\begin{array}{l}\text { The focus is on strategic and policy issues. } \\
\text { Coordinates the Regional Boards. The } \\
\text { Chair of AKES and AKHS are ex-officio } \\
\text { members of the National Council. }\end{array}$ \\
\hline Grants and Review Board (GRB) & $\begin{array}{l}\text { An independent audit component. It has a } \\
\text { mandate from the Imam to audit all the } \\
\text { Board programs. }\end{array}$ \\
\hline $\begin{array}{l}\text { Ismaili Tariqah and Religious Education } \\
\text { Board (ITREB) }\end{array}$ & $\begin{array}{l}\text { An independent Board that oversees the } \\
\text { religious education within the Jamat. }\end{array}$ \\
\hline Social Welfare Board (SWB) & $\begin{array}{l}\text { Concentrates on the immediate welfare } \\
\text { needs of the Jamat. }\end{array}$ \\
\hline Youth and Sports Board (YSB) & $\begin{array}{l}\text { Oversees issues of relevance to the Youth } \\
\text { of the Jamat. This includes sports activity } \\
\text { and education. }\end{array}$ \\
\hline Economic Planning Board (EPB) & $\begin{array}{l}\text { Oversees the potential employment and } \\
\text { educational upgrading for members of the } \\
\text { Jamat. }\end{array}$ \\
\hline AKES Jamati Committee & $\begin{array}{l}\text { Looks at the education needs of the Jamat } \\
\text { and determines how it can be integrated } \\
\text { into AKES. }\end{array}$ \\
\hline AKHS Jamati Committee & $\begin{array}{l}\text { Examines the health needs of the Jamat } \\
\text { (e.g. prevention and education). Also, } \\
\text { financial assistance for the vulnerable } \\
\text { populations within the Jamat. }\end{array}$ \\
\hline
\end{tabular}

19 The Women's Development portfolio was not considered to be an active portfolio in Tanzania. The regional Councils are responsible for implementation. For example, designated education and health representatives would engage with the AKES and AKHS Jamati committees. However, these were not comprehensive Boards as was in the Canadian context. 
However, as will be discussed in the Community and AKDN section, there has been a shift in the focus of $\mathrm{AKDN}$ to a broader mandate that has implications for how community needs are integrated. The structure of the Council in Tanzania, as well as the interrelationship with the Jamati committee, is explained by a member of the leadership as follows:

[At] the National level you have ITREB, Economic Planning, Health, Youth, Education, [and] Welfare. The same [structure] is at the regional level. [...] [The National level] [...] pass the decision-making to the regional people [...]. National would tell his regional member and [the] regional [member] through [the] committee level would try to make sure it's implemented. [...] (interview 18)

It was noted that the National Council focuses on strategy and policy issues while the regional level focuses on implementation. The link to the Jamati Health and Jamati Education committees of AKHS and AKES was described as coming into play more at the regional level. However, if there were issues of coordination or support, the National level of the Council would connect with the Chairs of AKHS and AKES (interview 18).

The mandates of the various Boards are described in detail in the Canada case study chapter. However, it was clear that in the Tanzanian context, the focus was very much dedicated to immediate needs and issues of poverty alleviation. As well, the limitations of financing programs and services were at the forefront. As such, the scope of services and the capacity for long-term strategic thinking is limited compared to the Canadian context. Also, some portfolios such as Women's Development were not considered very active within the Tanzania Council (interview 19). As discussed in the Canadian chapter, in line with the guidance of the Imam, there has been a move to a more thematic approach. The potential for interconnection between the various Boards in Tanzania was explained as looking at a particular need, for example, increasing 
continuing education within the Jamat, and then designating a Board to take responsibility and coordinate with other relevant Boards (interview 18).

Some Boards are taking their own initiative to move in a more thematic direction. For example, a joint committee between Youth and Education was a way to help identify suitable candidates for Aga Khan Education Services (interview 20). Also, the Social Welfare Board noted the connection with the Economic Planning Board in exploring options for job placement and business counselling (interview 19). Although there are pockets of connection between the Boards, the focused thinking and planning around specific themes is still rudimentary compared to the Canadian context.

\section{Rationale for Ismaili Community services}

The rationale for services at the initial phases of Ismailis living in East Africa was very much based on the evolution of the needs of a growing community. The focus was on the health and education of the community starting from small education classes and health clinics, and then growing into formal schools and hospitals. Housing cooperatives, banks, and insurance assisted the community in engaging in the market, and in turn this helped foster self-reliance in a colonial context. As well, the different political contexts in which Ismailis found themselves in Tanzania from colonial rule to socialism to a more open economy reinforced the need for self-reliance at the Ismaili community level. It fostered independence from needing a state-based welfare system. The focus on selfreliance and independence continues today with the community level responsible for the donation driven component, and the Imamat level covering administrative costs. However, since there are no comprehensive safety nets for welfare services in Tanzania 
and there are limitations at the community level to generate the necessary funds, it can make focusing on self-reliance and independence problematic. As well, differences of income at the Ismaili community level may unintentionally reinforce aspects of selfreliance and independence that question the need to participate in donation driven mechanisms of welfare. The focus on self-reliance and independence might have created an expectation that the needs at the community level have been resolved, as AKDN moved to a broader mandate. However, this is not the case. And since the focus on poverty alleviation is approached in a targeted manner, issues of stigma and potential detachment at the community level may be an issue. Although there is recognition that precautionary programs and creating an environment that help foster self-reliance and build capacity is ideal, the situation of the Tanzania Jamat dictates a focus on more immediate needs. As such, issues of quality of life and social care are seen as longer term goals compared to more immediate needs (interview 19). As identified by a member of leadership in the National Council for Tanzania, programs are dependent on funding at the community level, but if that funding is unavailable, the program initiation and implementation have to be re-evaluated (interview 18).

\section{Funding and Redistribution Ismaili Council in Tanzania}

The pressure on the Council in Tanzania to address a multitude of Jamati needs without any state support or leveraging external sources has led to a high level of frustration. Since the local services such as the Social Welfare Board are dependent on the local Jamati development funds, it has created a situation where Ismailis with 
sufficient means are experiencing a high level of donor fatigue. This was expressed by a member of the National Council executive as follows:

[...] Whatever we have done through [the] Social Welfare has helped. I'm not saying it hasn't, but I think we need to do a lot more. [...] There [is] a very small section that is doing well. Others are meeting their ends, and others are really struggling to meet ends. [...] There is donor fatigue because everything we do, we go to the same people [...]. (interview 18)

Fundraising in a small Jamat where the socio-economic differences are skewed more to those needing assistance becomes a challenge. The strategy for fundraising is focused on approaching individuals that have supported initiatives in the past. There are also individuals that directly offer their support to the Council. For example, there are specific initiatives such as sponsoring a child where an individual within the community commits to providing the necessary funding for a child's school tuition (interview 18). There is also a need to secure funding for individuals without the resources for overseas medical treatment. It was noted that services in Tanzania were not always adequate, so it was necessary to seek treatment in Pakistan or India (India was seen as being more costeffective) and for emergencies Kenya or South Africa were options (interview 18).

Another interviewee said that the Social Welfare Board does its own fundraising in the community, but some Jamati members choose to donate directly to individuals in need (interview 19). The push to formalize welfare in the community and measure outcomes can in some ways exacerbate issues of stigma. Thus, some members of the Jamat may choose to address vulnerabilities directly on a one-to-one basis. This will be discussed in more detail in the section on challenges faced by the Council. As in Canada, it was noted that funding for Council administration is provided by the Imamat level (interview 19). 
There is a level of frustration that the core Ismaili community is not fully being serviced yet resources are being allocated to the expansion of AKDN projects that are not directed to Ismailis. The conundrum of an institution progressing beyond its core community and engaging with donors and constituents that have other demands is apparent. Although the Constitution notes the need for Councils "to work in close collaboration with other Councils in different regions of the world and with the Aga Khan Development Network" (Aga Khan IV, 1986, p.14), the capacity to do so is not straightforward. The funding of programs and services are no longer exclusively concentrated from the resources of the Ismaili community. Instead, it has gone beyond the community level to include governments, donors, and private equity investors. As such, linking the community level to the broader mandate becomes more difficult. There is a sense that $\mathrm{AKDN}$ entities need to be strongly positioned as non-denominational and not prioritize the Ismaili community. Nonetheless, it was noted that the Imamat level would like to see collaboration between the community and the broader AKDN continue (interview 18). However, it is unclear exactly what that collaboration should look like and if there should be any financial obligation on the part of AKDN profit-making entities to the welfare of the Ismaili community. This idea of a potential financial responsibility of AKDN profit entities to the Jamat was expressed by an executive of the Tanzania National Council as follows:

[...] I feel there is a lot of these [AKDN] agencies [that are] financially doing well [...]. I would have expected that some of those profits should actually filter to the Jamat. [...] I feel when it comes to discussion and contribution it is there, but I believe there has to be a financial [component]. [...] (interview 18) 
The issue of some AKFED entities being listed on the stock exchange was acknowledged as a potential limitation to providing financial support directly to the Ismaili community. Nonetheless, the issue of how profits were distributed was seen as an area of flexibility, and it was reiterated that the community structures could not be run exclusively on fundraising from individuals within the community (ibid.).

\section{Links with other Councils Regionally and Internationally}

The regional links between Councils in East Africa as in the Canada case study occur on an ad hoc basis. Again, there is the potential for overall strategic input at the Leaders International Forum (LIF) that includes Council Presidents worldwide. The possibility for sharing financial resources regionally in East Africa is not in the range of thinking at this point. This is despite the higher level of socio-economic stability within the Kenyan Jamat, for instance. There were some examples of regional links. The Youth and Sports Board had informal relationships with Council counterparts in Kenya and some contact with individuals in Uganda. As well, there were more opportunities for coordination when specific sporting events were organized on a regional basis (interview 20). The Social Welfare Board interviewee noted that at present the Social Welfare Boards are set up as individual Boards and as such there was no regional focus or sharing of resources (interview 19).

The move toward more of a formalized regional structure with the East African Union (EAU) as well as the regional structures already in place within AKDN may help to strengthen the regional level of coordination among Councils. One member of the Council leadership in Tanzania expressed surprise that there were no formal regional 
mechanisms at the community level given the regional level of coordination within AKDN entities (interview 18). He noted that there is a need for the community to be meeting systematically on a regional basis to exchange ideas.

\section{Ismaili Community Links with Government and External}

The relationship of the Ismaili community and the Government in Tanzania has shifted from one where the onus was on the Council leadership to engage with government to one where there is now a formalized AKDN resident representative that has taken over this role. This has led to an interesting dynamic. Although AKDN has shifted its focus from the Ismaili community to a broader mandate, when it comes to critical relationships with government, AKDN takes the lead role. It was described as a potential marginalization of the Ismaili community as other communities are directly in contact with government while in the Ismaili community context there is now an AKDN intermediary that has taken over that link with government (interview 18). Also, it was noted that there is a level of confusion on the part of government about which body (e.g., the Council or the AKDN representative) represents the Ismaili community in Tanzania. An individual in the National Council explaining the situation, stated:

[...] I feel personally that by AKDN being there the community is also marginalized. I would have rather preferred both the community and AKDN are invited to these things [i.e., government functions], so we have a chance to meet people as well [...] (interview 18).

Although it was acknowledged that there is collaboration and information exchange between the AKDN representative and Council, it was articulated that the community was missing out on building critical relationships with government. The need 
for the Council leadership to have a sense of the overall national direction of health and education issues was deemed important (interview 18).

\section{Challenges}

Several challenges came to the forefront in the Tanzania case. The constraints on both financial and human resources were key issues. The lack of government or other external support combined with the financial issues within the community has exacerbated the scope of the challenges. The Jamat in Tanzania is small and the potential for anonymity is less. Thus, the willingness to utilize services that are available can be an issue. There was a more informal assistance system in place whereby individual members of the community would help another member on a one-to-one basis. However, within a more formalized Council structure and being accountable to the Imamat level, there is a greater expectation to provide details regarding outcomes of the services, as well as having a monitoring component in place. A member of the National Council executive discussed the potential of stigma for those seeking help from the Social Welfare Board:

There is a lot of stigma. [...] There are a lot of family members that don't go [for help to the Social Welfare Board] because they feel psychologically it puts them off. That they are there for a handout. [...] We were actually doing it separately before, but when you are sitting in meetings with $\mathrm{HH}$ and he asks ok so how many are we helping. We don't have a figure because National Council does its own way, regional... The last five years, it has been said let's centralize it. [...] (interview 18)

It was suggested that stigma can also be an issue because individuals are now going to a designated place for assistance, and there is a level of monitoring. The interviewee indicated that helping individuals discretely as previously was the case would be preferable (ibid.). 
The level of information provided to the Imam may not always be complete. This could be because the information is not available such as when multiple levels of the Council are all providing assistance. Also, there may be a sense that individuals seeking assistance may not want to be seen as unable to meet the expectation of self-reliance and independence, so there may be an incentive to help individuals on a one-to-one basis rather than bringing it to the attention of the Imam. There may also be aspects of trying to exert a level of control over community affairs by appointed leadership in a context where the Imam is the unfettered authority. Another area related to stigma is the perception within the Ismaili community of the Social Welfare Board itself, and the difficulty the Board has in reaching out to community members in need. Hence, it is difficult to market the program, and this is compounded by of the lack of alternatives available in Tanzania. The challenges facing the Social Welfare Board encompassed several areas, including institutional, family, human resources, financial and other factors. The institutional issues noted were policies of AKES that would result in expulsion of students who did not meet grade requirements. Also, the difficulty in negotiating agreements with families when they are part of a religious community was noted. In the area of family, issues highlighted included difficulties assessing true income and selfinitiative for development. Human resources challenges included the lack of professional training for volunteer and paid personnel. Financial challenges were linked to diminished donations because of the internal capacity of the Jamat and the overall economic slow down. Other challenges noted were the increased cost of living including health and education, a low-pay scale and inadequate opportunities for continuing education (interview 19). 
The level of coordination of the National Council in Tanzania with its regional Councils responsible for implementation was identified as an area where more clarity and enhanced communication would be beneficial (interview 18). The overall success of Council was seen as dependent on resolving coordination issues between national and regional levels. Another interviewee reiterated that overall links with other areas in Tanzania, for example, "upcountry" was weak, but a flat structure in his particular Board was seen as allowing for the creation of specific links (interview 20). The need for a fulltime CEO to coordinate the overall activities of the Council as well as the need for financial resources to come from both the community and externally was highlighted (interview 20).

The issue of individuals who have the financial resources or were talented recent graduates deciding not to continue living in Tanzania was another barrier highlighted (interview 20). This affects the capacity to generate resources and grow the community structures in the areas of volunteer service, financial support, and leadership. The lack of opportunities available in the country for youth was a related area of concern. For example, one interviewee noted that with less perceived opportunities, some Ismaili youth are dealing with issues of self-motivation and not prioritizing education, as was previously the case. Also, the difficulty in to sourcing funding for education can be a barrier to further education (interview 20). The need to encourage the engagement of women in generating a secondary income was seen as important to help stabilize income levels within the family (interview 18).

The need assessments conducted in Tanzania for Jamat programs and services are informal. The needs are determined by relying on a general understanding of jamati needs, 
interviewing families when possible, and getting feedback from leaders of the Jamat to determine the types of programs and services to implement. One interviewee noted that any formal needs assessment may increase the expectation of the Jamat, and the Council would be unable to deliver given the multitude of constraints and the limited budget (interview 19). However, it was noted that the quality of life Programs that were initiated by Aiglemont during the Golden Jubilee were based on research within various segments of the Jamat worldwide (ibid.).

\section{AKDN in Tanzania}

\section{AKDN Overall Structure and Governance in Tanzania}

The current focus of AKDN in Tanzania has evolved with the changes in the political circumstances since Ismailis were first in Tanzania. As noted previously, the height of Ismaili concentration in Tanzania was in the 1960's. This was reflected in the number schools, sixty-five at the time. The AKES is currently operating three schools (nursery, primary, secondary) in Dar es Salaam and a primary school in Mwanza. The governance structure of AKES, as highlighted in the AKDN chapter, is similarly described by a senior member of AKES in Tanzania. There is an AKES Board of Directors that is nominated by His Highness with individual Ismailis having always been part of that structure. It was noted that there is also one or two non-Ismaili individuals who are appointed to the Board. The hierarchy was described as ultimately His Highness with the Social Welfare Department having two representatives who sit as directors on all AKES Boards (interview 25). This allowed for consistency at the local level and an understanding of expectations before budgets were approved by His Highness. 
The precursors of AKHS had a presence in Tanzania as early as 1929. There was a dispensary offering free medical services. The next step was to focus on maternal health, and in 1939 a maternity ward was opened. Later, a nursing facility with surgical capacity opened in 1948 and in 1964 the Aga Khan Hospital was built. In addition, various medical centres were established in various towns in Tanzania (AKDN, 2007k). The vision for the Hospital today, was described as a long-term medical sciences centre that encompasses a high level of service and provides medical training. The governance side of AKHS is composed of six committees including Quality Control, Finance, Human Resources, Primary Medical Centres, Jamati Health and Marketing (interview 22). A senior member of AKHS operations described the relationship of AKHS and Aiglemont as follows:

$[\ldots]$ There is a Board, a management structure in place and other operative structures, but essentially we still have a very strong ongoing relationship with Aiglemont and communication with Aiglemont. [...] in terms of governance structures, we have our Board, [and] we have the Social Welfare [Department] at Aiglemont headed by Princess Zahra Aga Khan. Also, [it] includes the National Council [and] other agencies like the GRB. It is quite an expansive structure in terms of governance. And I think the structure is actually a good one. It brings in the community. It brings in national agencies and links it up all the way to Aiglemont. [...] (interview 21)

AKF has had a presence in East Africa (i.e., Kenya) since 1974 and in 1991 AKF was established in Tanzania (AKDN, 2007). AKF works on a regional basis today in East Africa, and there is a combination of national and regional structures. A senior member of the governance structure of AKF, East Africa, described the interplay of the regional committee and country coordinating committee. He stated:

$[\ldots]$ we have a regional committee and then every country has $[\ldots]$ a country coordinating committee, and [the] regional committee has a Chair and two Vice Chairs. [...] the way East Africa committee [is] at the 
moment [is it has] members from Uganda, Kenya [and] Tanzania. A country coordinating committee is $[\ldots]$ in charge of the country. $[\ldots]$ the country coordinating committee are then reporting to the regional committee. $[\ldots]$ we also have $[\mathrm{a}]$ regional CEO, [...] regional program directors, [and] regional [program] officers [...]. (interview 29)

Furthermore, how AKF in East Africa interacts with AKF in Geneva and ultimately $\mathrm{HH}$ was described by an AKF executive officer in Tanzania as follows:

[...] [the] AKF Board [in Geneva] is chaired by HH. [...] that is extremely important because in our context we don't have a National Committee. We have a regional committee because AKF in East Africa is regional and functions as a regional institution with their head quarters in Nairobi. [...] (interview 28).

The Aga Khan University has been active in East Africa on a unit specific basis since 2000, and it is now involved in developing comprehensive programs in health sciences and education (AKDN, 2007e). The AKU focus currently includes Advanced Nursing programs, Post Graduate Medical Education as well as a regional Institute for Educational Development located in Tanzania. In addition, a regional University to be located in Arusha, Tanzania is in the planning and development stages. The structure of the AKU is an interesting mix of local, regional, and international components. As well, the University has unit-based structures. For example, AKU-IED in East Africa is closely linked to AKU-IED in Karachi. The overall University has a President based in Karachi with an international Board of Trustees including the Aga Khan who is also the Chancellor of the University.

The area of Micro-insurance is a relatively new initiative and part of the Aga Khan Agency of Micro-finance (AKAM). There is also a link between micro-insurance and Jubilee Insurance in Tanzania. The Micro-finance initiatives are overseen by AKAM in Geneva. 
The AKFED institutions that were examined in this dissertation include the Diamond Trust Bank that is regionally structured with banks also in Kenya and Uganda.

The structure was described as one that considers the local realities and banking laws with regional support with reports being consolidated at the global level. Similarly, Jubilee Insurance is part of a regional structure, but it seems that it is more of an affiliate of the structure in Kenya that then sends reports to be consolidated at the global level.

Table 5-6 Key AKDN entities in Tanzania

\begin{tabular}{|c|c|}
\hline AKDN Resident Representative Office & $\begin{array}{l}\text { The mandate of the AKDN resident } \\
\text { representative includes creating links with } \\
\text { government and harnessing the potential } \\
\text { synergies between the AKDN entities. The } \\
\text { AKDN representative office acts as a } \\
\text { conduit in getting donors to the table with } \\
\text { various AKDN agencies. }\end{array}$ \\
\hline AKF, East Africa & $\begin{array}{l}\text { A coordinating body for AKF’s in East } \\
\text { Africa. }\end{array}$ \\
\hline $\mathrm{AKF}$ & $\begin{array}{l}\text { Expertise in areas such as early childhood } \\
\text { development, maternal health, rural support } \\
\text { programs, agricultural development, and } \\
\text { civil society strengthening. Described as an } \\
\text { "honest broker" for key development } \\
\text { issues. Plays a facilitative role in getting } \\
\text { stakeholders together and engages in policy } \\
\text { formulation. }\end{array}$ \\
\hline AKES & $\begin{array}{l}\text { Currently operating three schools (nursery, } \\
\text { primary, secondary) in Dar es Salaam and a } \\
\text { primary school in Mwanza. }\end{array}$ \\
\hline AKHS & $\begin{array}{l}\text { Operates a Hospital in Dar es Salaam and } \\
\text { health clinics in various locations in } \\
\text { Tanzania. The health clinics are in } \\
\text { partnerships with the government to } \\
\text { provide maternal health and child } \\
\text { immunizations. }\end{array}$ \\
\hline
\end{tabular}




\begin{tabular}{|l|l|}
\hline AKU-IED-EA & $\begin{array}{l}\text { A regional Institute for Educational } \\
\text { Development focuses on improving } \\
\text { educational standards in primary and } \\
\text { secondary schools as well as school } \\
\text { management and leadership. It offers a } \\
\text { Master's of Education (MEd) in Teacher } \\
\text { Education and a Certificate in Education. }\end{array}$ \\
\hline AKU-PGME & $\begin{array}{l}\text { The academic component of the Hospital in } \\
\text { Tanzania. It is a post-graduate program. } \\
\text { Family medicine is the only PGME } \\
\text { program offered in Tanzania. }\end{array}$ \\
\hline AKU-ANS & $\begin{array}{l}\text { It offers diploma programs to upgrade } \\
\text { nursing skills and a Bachelor of Nursing } \\
\text { program. }\end{array}$ \\
\hline Jubilee Insurance Group & $\begin{array}{l}\text { It provides a full range of insurance } \\
\text { products to clients. }\end{array}$ \\
\hline Diamond Trust Bank & $\begin{array}{l}\text { It provides banking services to business } \\
\text { and retail clients. }\end{array}$ \\
\hline First Microinsurance Agency (FMiA) & $\begin{array}{l}\text { A relatively new initiative in Tanzania and } \\
\text { part of the AKAM. There is also a link } \\
\text { between micro-insurance and Jubilee } \\
\text { Insurance in Tanzania. }\end{array}$ \\
\hline First Microfinance Agency (FMFA) & $\begin{array}{l}\text { The Micro-finance initiatives focus on poor } \\
\text { and vulnerable populations. The aim is to } \\
\text { enhance self-reliance. AKAM oversees the } \\
\text { initiatives. }\end{array}$ \\
\hline
\end{tabular}

\section{Synergies}

Several interviewees identified the role of the AKDN representative in spearheading synergies between AKDN entities. The mandate of the AKDN resident representative includes creating links with government and harnessing the potential synergies between the AKDN entities. The AKDN representative office is also a conduit in getting donors to the table with various AKDN agencies (interview 29). An informal AKDN group in Tanzania that consists of all the heads of AKDN entities and the National Council Chair was identified as a key mechanism to explore synergies. It also 
allowed for sharing information regarding legislation or local issues that could facilitate working in the region (interview 30). As described by an AKF interviewee "if there are any government issues or policy issues with the government we really take [advantage] of the AKDN [representative] position. That is where they come to our help if possible in discussing with different Ministries or government officials of programs and other policies" (interview 29).

On the practical side, several interviewees identified the benefit of being able to purchase goods and services as a group. Also, cross-links between entities were identified, for example, Diamond Trust Bank insures with Diamond Trust Insurance. There were informal norms whereby the services of fellow AKDN agencies would be considered first before a decision was made (interview 32). The fact that AKDN encompasses a diverse group of entities was seen as beneficial as entities did not have to work in isolation, and there was the benefit of an overall AKDN Committee at the Imamat level that could help coordinate the various AKDN entities. There were some specific examples identified of interagency synergy, the challenges in creating synergies and suggestions for increased coordination.

A move to focus on overall health sciences at the Hospital brought to the forefront the need for a cultural shift from one previously focused solely on service delivery to one that incorporated an academic and a learning environment. For example, in locations such as Karachi and more recently Nairobi, the Hospital and University are under one umbrella. However, in Tanzania, the attempt to integrate academic (i.e., post graduate medical education - AKU) and service (the Hospital part of AKHS) was described as a mismatch. This was because the necessary infrastructure and culture to support an 
academic environment within a previously dominant service based incentive structure was deemed not yet in place (interview 24). For example, a senior member of the management team of the hospital noted that there was a need to "create that cohort, that nucleus of people who are clinical and administrative leaders who understand the business of health science education and [are] willing to be engaged in it" (interview 21). For the nursing training programs, the acute human resource limitations both on the hospital and academic side were identified as barriers to engagement in academic training programs (interview 34).

There were links that were identified between AKDN components, but they tended to be segment specific. For example, in the area of education there were cross-link appointments identified between the local AKES Board and the AKU Board (interview 26). This was seen as a mechanism for AKES to be a potential "pipeline" of students for the Aga Khan University in East Africa (interview 26). As well, teachers within the Aga Khan Schools structure were engaged with the AKU-IED programs (i.e., Master's of Education program).

AKF was identified as playing an important role as a conduit for potential donors and other AKDN agencies. This would include seeking funding for specific programs within the health and education segments of AKDN (interview 29). A government clinic in Zanzibar that was managed by AKDN brought together the two components of AKF and AKHS. It is a primary health clinic, and this is an area of specialization of AKF while AKHS brings its technical expertise in the area of health systems management (interview 33). 
An executive officer at AKF in Tanzania summed up the potential and scope of synergies of the different AKDN agencies in Tanzania by describing the benefit of a socalled Multi-Input Area Development (MIAD) approach. The interviewee noted that HH would like to see an impact that "is greater than the sum of its parts" (interview 28).

For example, it was suggested that if AKF is doing work in a particular community and the Aga Khan Agency of Micro-finance (AKAM) is also present there is a potential for a group of individuals that have benefited from AKF programs to join together and perhaps seek a group loan for a particular business initiative from AKAM. Thereafter, deposits from the business could be made at the Diamond Trust Bank, and then perhaps the group could make use of the services such as Jubilee Insurance. There was also the potential of selling products to the for-profit segments of AKDN. Also, the potential of utilizing the services of the social component such as AKHS was noted. The potential for such a model in Tanzania was described as needing exploration, but it was acknowledged that it takes time for all the agencies to be active in a particular geographic area (interview 28).

\section{Rationale of AKDN Components}

The rationale of AKDN programs has evolved as shifts have occurred from its predecessor institutions being more community-based entities to now focusing on a broader segment of the population. The Imamat level responsibility for a dual mandate necessitates moving to a broader scope in both the for-profit and non-profit entities of AKDN. These shifts were in some ways propelled by changes in legislation during the colonial period. For example, changes in colonial legislation allowed the institutions to 
offer services beyond the community level (AKDN, n.d). In a sense, the trajectory of AKDN is closely aligned with the political history in East Africa (ibid.).

The capacity for AKDN to influence the environment where it operates has been an important factor. For example, in 1986 the Aga Khan Foundation was the lynchpin in bringing together relevant sectors and drawing attention to the importance of an enabling environment at a conference in Nairobi, Kenya. The conference was described as being instrumental in "highlight[ing] the crucial and complex relationship between civil society and development, between effective legislation and individual enterprise, and between macro-economic and growth" (AKDN, n.d, p. 4). The focus on understanding development as a complex process that requires engagement of multiple actors in the areas of social, economic as well as culture has been an ongoing theme. As well, the focus on values such as independence and self-reliance underlines the thinking of both Council and AKDN institutions.

A leader within the banking sector noted that at its inception the focus was on the Ismaili community. The bank was an initiative in 1946 to mark the Diamond Jubilee of Aga Khan III and was called the Diamond Jubilee Investment Trust Company Limited (DJIT) (AKDN, 2007e). Unlike in Kenya where the bank continued to grow as a commercial enterprise, this was not the case in Tanzania. There was a slow down in development during the socialist phase in Tanzania as it created a lack of incentive for private enterprise (interview 32). However, in 1991, after the AKDN signed a protocol agreement with the Government of Tanzania, there was an infusion of capital and the banking segment was reactivated as a commercial entity. In 1997, the bank was considered a fully functioning bank, and there was a distinct shift from a community to 
commercial enterprise by describing the Bank as a Tanzanian financial institution (interview 32). It was noted that there is still a connection to the Ismaili community, but as the Bank continues to grow, the needs of the Ismaili community are being overtaken by the broader segment of the Tanzanian population utilizing the services (ibid.).

Similarly, the insurance segment of $\mathrm{AKFED}^{20}$ was described as starting at the community level in the 1930 's with a focus on community needs. The Jubilee Insurance Group was initially incorporated in Kenya in 1937 and then opened in Tanzania (AKDN 2007e). However, the overall business objective even in the early phases was described as not being confined to the community level but with a vision to grow and expand to a real commercial enterprise (interview 30). Currently, the insurance segment was described as a sort of Pan-East Africa entity that had markets in Kenya, Uganda, Tanzania and a new initiative in Burundi (ibid.).

The rationale of AKF was described as having specific sectoral competencies and the capacity for engaging in innovative approaches within the context of national priorities. The rationale was tied to broader development themes and expertise in areas such as early childhood development, maternal health, and rural support programs. Furthermore, AKF was seen as taking on the role of an "honest broker" for key development issues in the region (interview 28). As well, the emphasis on being nondenominational and not focusing on the Ismaili community in East Africa was noted (ibid.).

Initiatives such micro-insurance were described as serving a need to empower low income households by providing protection that was lacking. Also, the various education

\footnotetext{
${ }^{20}$ Components of AKFED that were not part of this dissertation include Industrial Promotion Services (IPS), Tourism Promotion Services (TPS), as well as Media services.
} 
financial products were identified as a mechanism for helping women (interview 31). Women were identified as being able to sustain that balance between economic needs and fostering social goals such as education and health within the family (interview 28).

The focus on quality, impact, access and relevance in programs and services were identified as guiding principles for the AKU Institute for Educational Development (interview 27). These ideas were reiterated by others interviewed especially related to services in the Primary Heath Centres that were connected to the Aga Khan Health Services (interview 33). There is also an internally funded welfare component at the Hospital level. There are three components of targeted welfare in the hospital context, one that focuses on government employees which is part of an agreement with the Government of Tanzania, disadvantaged members of the Ismaili community and the general population (interview 21). There are plans to incorporate external funding for welfare programs as is the case in Karachi and more recently Nairobi (ibid). The limited options for health and education were also identified as necessitating services of the AKDN social segment. For example, substandard facilities in both the education and health sectors were identified as areas that needed innovative solutions as well as leadership in terms of engaging with government regarding direction.

\section{Role of volunteers}

Despite the shift from the community level to broader segment of the population, there is a continued connection between individual Ismailis and AKDN. This connection is apparent in the area of engagement of individual Ismailis in volunteer and leadership positions throughout the AKDN. The idea of voluntary service was seen as being instilled 
within members of the Ismaili community from a very young age, and volunteering within AKDN was seen as a continuation of that service (interview 23). The engagement of volunteers not only from the region but internationally was noted. For example, the Ismaili Health and Professional Association bring their expertise to AKDN health institutions (interview 22). The volunteer capacity is also prominent within the governance structure of AKDN institutions. The importance of Ismaili volunteers in the overall functioning of programs was also highlighted (interview 29). The recent implementation of TKN was another source that was referenced as a way of engaging Ismailis with the work of AKDN. The act of volunteering can be seen as a way to connect to the Imam, and AKDN can be seen as the conduit where individual Ismailis can demonstrate their commitment to the Imamat institutions.

The engagement of individual Ismailis in the AKDN structure is not necessarily the result of the influence of the Ismaili community per se, but the attempts of individual Ismailis manifesting the direction and vision of His Highness. The potential influence of His Highness on volunteer engagement by members of the Ismaili community was described by an executive officer at AKF in Tanzania:

[...] I think you have to ask yourself first is that the influence of the Ismaili community or is it the influence of the Ismaili community in part large or small due to the influence of His Highness. [...] [For example,] the TKN has allowed AKF to tap into Ismaili volunteers which has served to highlight the importance and key contribution of volunteers to AKDN as a whole, but it has also highlights the commitment that the Ismaili Jamat has to AKDN without being in a way that is overbearing to anyone who is not Ismaili. (interview 28)

Also, the role of volunteers outside the Ismaili community was acknowledged, especially as the scope of AKDN has grown. In addition, the role of non-Ismailis in the 
governance structures was described as a way to foster understanding of the Ismaili community's link to AKDN but in a way that was transparent (interview 29). In addition, one interviewee noted that "a key element of AKF programming is to develop social capital and fostering volunteerism" (interview 28).

\section{Social v. Economic Components of AKDN in Tanzania}

The issues of self-reliance and self-sufficiency are at the forefront of both the Social and Economic components of AKDN. The underlining aspect of self-reliance has to some extent always been a theme even when the focus was at the community level. The Imamat level is still involved in funding capital investment, and during the initial phases, there was a reliance on the Imamat level and donors to sustain the functioning of the non-profit segments. However, there is a push to a business model structure or as previously described a "para-company" structure that would allow for self-sustainability of even the non-profit entities. This is particularly the case in the hospital context where there is greater potential for revenue generation, especially with an aggressive twentyyear plan that aims to position the hospital as the premier institution in Tanzania. This was expressed by a senior member of the Hospital's management team as follows:

[...] we are not interested in making huge profits. That is not the goal of AKDN, but you have to be sustainable to meet your operational budget. [The] ongoing capital investments for the strategic investments HH still funds it, [...] but he does expect that institutions will be reasonably selfsufficient which takes you [to] more of a business model. [...] (interview 21)

There are some links between the Social and Economic components of AKDN. For example, Jubilee Insurance is the underwriter for the First Micro-finance Insurance Agency. Also, micro-insurance is a new initiative that required adjustments to the 
regulatory framework that Jubilee Insurance was involved in working with the government to establish.

There were health initiatives such as clinics to increase the awareness of HIV, breast cancer and diabetes that were sponsored by the insurance and banking sectors of AKDN. However, the need for a more coordinated effort in the area of social corporate responsibility as well as an increased budget for assistance to the non-profit side was identified (interview 32). It was noted that there is an effort being made to examine Network based initiatives for linking the economic and social components of AKDN in more focused ways (ibid.).

\section{Funding for AKDN}

The funding for AKDN components varies. As discussed in the background chapter of AKDN, the funding for AKFED components such as the Bank and Insurance are self-sustaining. New initiatives of AKFED secure funding based on sources similar to other private enterprise (i.e., banks and international lending organizations).

AKHS falls more in the area of self-sustainability, although capital assets continue to be funded at the Imamat level (interview 21). In education, there is a mix of school fees and donor funding as well as some scholarships on a needs basis. For example, AKU-IED, EA has a system of fees in place, but programs are subsidized by AKU and the sponsoring agencies of candidates provide funding (interview 27). A similar structure is in place for the advanced nursing programs. The elementary and secondary schools of AKES are private, so user-fees are a large component of funding. The target market for the private schools is middle to high-income families. This brings to the forefront the potential trade-offs in having initiatives that are considered distinctive 
and focusing on a niche segment of the population. However, it was suggested that scholarships were seen as an area to develop as it would help assure government as well as allow a broader segment of society to benefit from quality primary and secondary education programs (interview 26). Also, there are programs in education such as the School Improvement Programmes that act as a catalyst and provide teacher training to various government schools. As well, there are programs that are specifically focused, e.g., early childhood development programs that service poorer communities.

The extent to which the Ismaili community contributes to AKDN initiatives still occurs either as individual donors or through funding that gets filtered from the Imamat level. However, unlike in Canada where initiatives such as the World Partnership Walk bring in a large number of individuals from the Ismaili community both as volunteers and financial contributors to support initiatives, such initiatives are not organized in Tanzania. As well, AKF in Canada has access to the Jamat to describe the work of AKF and initiate fundraising initiatives. This is because AKF's in the developed countries have traditionally been considered the resource generators for the AKF's in the developing countries. As described by a senior member of the governance structure of AKF in East Africa, the Ismaili community in Tanzania is a source of funding for the National Council rather than AKF (interview 29). It also points to the limited resources of the Ismaili community in the Tanzanian context. However, there have been other fundraising efforts such as funding for the University where funding from large and small donors comes from across the globe. 


\section{Challenges}

The range of challenges that an organization such as AKDN faces is one that is difficult to discuss in its totality given the diversity of agencies and the local, national, international, and regional dynamics that come into play. Nonetheless, it is helpful to highlight some key issues that could illustrate the complexity of encompassing aspects of a logic of hybridity that sometimes has competing interests in terms of its trajectory of growth and trying to maintain a connection to the Ismaili community, especially those individuals that are the most vulnerable. As well, limitations in human resource capacity and issues of standards in a developing world context are discussed. In addition, taking on the position of catalyst and innovator in areas of economic development, social and culture bring its own challenges.

One example that illustrates these tensions is in the area of tertiary education and forging ahead to create a regional university. An interviewee from AKU-IED-EA pointed out that tensions among complex reporting lines at the local, regional and global levels can sometimes create frustrations and delays (interview 27).

The overall scope and speed with which AKDN has grown, it was suggested by a senior management officer of AKHS, has in some ways made AKDN more bureaucratic (interview 21). It was noted that the growth shows no signs of slowing down and having multiple large-scale projects in diverse parts of the world necessitates clear lines of coordination and responsibility (ibid.). Furthermore, it was noted that His Highness did not want to see a bureaucratic slow down (ibid.). The capacity for AKDN as a whole to maximize the potential synergies given the different areas of focus was also highlighted (interview 23). It was noted that there is still a tendency for AKDN agencies to approach 
issues on an individual basis and to protect their particular sector or agency (ibid). In a sense, AKDN is a composite of the various sectors with the Imamat level trying to orchestrate the maximum potential for blurring those divisions.

\section{Ismaili Community vis-à-vis AKDN}

As described previously, the Constitution provides possibilities for cooperation between the Council and AKDN, and the Central institutions of AKDN such as AKHS and AKES are linked to the Council via Jamati committees. The Constitution was promulgated in 1986, and there may have been a sense at the time that the knowledge base within the community and the existing structures of health, education, and to some degree economic development would continue to address the objectives of the Council as well as inform the broader mandate and structures of AKDN. For example, the Central institutions (Boards and AKES, AKHS) were described to be "for the furtherance of the aims and objectives of the Councils and also for contributing towards the implementation of programmes sponsored by one or more of the Apex Institutions" (Aga Khan IV, 1986, p. 16). However, given that the Central Institutions of AKES and AKHS straddle both the community and the overall AKDN structure, it creates the potential for non-alignment between the needs of the core community and the broader mandate. The relationship of Council and AKDN as it pertains to health and education and how it functions within the context of the dual mandate of the organization is explained by senior members of AKHS and AKES governance structures.

[...] AKHS, it falls under AKDN, but because we look after the health of our Jamat, we also fall under the umbrella of the Council. [...] This 
institution is [also] a social institution. It's His Highness's commitment [to] Tanzania [...]. (interview 22)

A senior member within the AKES governance noted that at Council meetings AKES is expected to provide a progress report of its work and articulate how the service company is addressing the education standards within the Jamat. It was noted that there is now more dialogue between the Council and the AKES with respect to the needs of the Jamat. However, the relationship between AKES and the Council is not without tension. This tension was described as follows:

I think [...] when you have leadership [...] that don't give enough information to the Council. There is a breakdown. Some of the Chairs who are Jamati based [...] or more involved with the community seem to have the pitch that would have the heart of the Jamat with them, and [...] that in many ways is carried through even at the Board level and would influence policy. [...] (interview 26)

Furthermore, it was noted that a proposed standing AKES agenda item that focused on the Jamat was accepted by the national AKES Board, and this will help to transparently demonstrate the importance of the Ismaili community and the reasons for AKES supporting it (ibid.).

The potential for non-alignment becomes more acute as the trajectory and growth of AKDN institutions continue beyond the institutions outlined in the 1986 Constitution. The impetus to take the needs of this small group into consideration in relation to the overall goals and mandate can vary depending on the focus of the individual appointed Chairs of AKES or AKHS and the capacity of the Council leadership to push for strong engagement. It brings up the question of whether there is a basis for real integration.

The focus on a broader segment of the Tanzanian population raises concerns regarding ensuring members of the Ismaili community do not fall through the cracks. It is, 
however, a more difficult task to direct resources around because the community is no longer the sole priority of the Network. Nonetheless, a member of the Council leadership pointed out that there remains a need for concrete financial assistance to address the multitude of immediate needs within the Ismaili community, and the potential of AKDN entities being a financial resource (interview 18). However, the community leadership assessment of what is a priority may not necessarily fit within the context of looking at the broader based mandate of AKDN. The mandate goes beyond the Ismaili community and is transnational in scope. As such, the priorities can shift even in areas that are deemed to be Central Institutions like health and education. The goal to some extent was for members of the Ismaili community with the initial assistance of the Council infrastructure and Imamat resources to attain a level of independence and self-reliance, and then as the Constitution notes to engage and contribute to the development of broader society. However, the differences in socio-economic levels within the Jamat in Tanzania remain a critical issue. Thus, the capacity for the Council to foster broader development engagement is limited.

Despite the Ismaili community not being the primary beneficiary of programs and services of AKDN in East Africa, the Network can still rely on Individual Ismaili resources. This is because for many within the Ismaili community, AKDN is equated with being an Imamat Institution and is positioned as such to the Ismaili community. It brings to the forefront whether there should be more talent and resources committed to community level services within the Council structure. This may help ensure that members of the Ismaili community are also moving forward in development initiatives in step with broader development goals. 
There is a definite contrast in the resource generation capacity of the more comprehensive AKDN structure with its links to government, donors, and the private sector compared to the Council's reliance on donations from the community level. However, the capacity for the Ismaili community to tap into services of AKDN is not as smooth as would be expected. The work of AKF, for example, is focused in areas that are relevant to poor and "ultra poor" populations, which do not necessarily encompass Ismailis in Tanzania. Other entities such as AKHS and AKES follow a "para-company" model where the focus is on self-sufficiency and surplus, so fees may be an issue. As well, within the Ismaili community context, the focus is on self-reliance and being able to engage with the market for products and services. As such, those individuals that are unable to afford services have to utilize the community level infrastructure (i.e., the Social Welfare Board and its links with the Jamati committees in Health and Education). However, as discussed, issues of stigma can come into play, and there are limitations to what assistance is available from the Jamati committees within the AKDN structure. There are overall subsidies on services, but the system is not setup as a rights based model whereby everyone is guaranteed a certain minimum. Instead, it is based on individual need and asking for assistance.

Table 5-7: Ismaili Community Utilization of AKDN Programs and Services

\begin{tabular}{|l|l|}
\hline Social Component & \\
\hline AKES & There is a nursery, primary and secondary \\
& school in Dar es Salaam and a primary \\
& school in Mwanza. Ismaili students do \\
attend AKES schools, but the proportion is \\
small compared to the overall student body. \\
The options for schooling have increased, \\
so Ismaili families may make other choices
\end{tabular}




\begin{tabular}{|c|c|}
\hline School improvement programs & $\begin{array}{l}\text { Various training programs for } \\
\text { administrators and teachers of government } \\
\text { schools in conjunction with the Ministry of } \\
\text { Education and Vocational Training. }\end{array}$ \\
\hline $\begin{array}{l}\text { AKU (PGME, ANS, Educational } \\
\text { Development). }\end{array}$ & $\begin{array}{l}\text { PGME, ANS and Educational } \\
\text { Development are broader based initiatives. } \\
\text { There may be a small number of Ismaili } \\
\text { students registered in these programs. } \\
\text { Ismaili students may also opt to study } \\
\text { outside Tanzania. AKU is in the planning } \\
\text { and building stages of a comprehensive } \\
\text { university in Arusha. This will be a strong } \\
\text { option for students considering tertiary } \\
\text { education. }\end{array}$ \\
\hline AKF (Costal Rural Support Program) & $\begin{array}{l}\text { The focus is on the regions of Lindi and } \\
\text { Mtwara, areas considered very poor. The } \\
\text { focus is on agricultural development, } \\
\text { health, education, enterprise development } \\
\text { and civil society strengthening. There is no } \\
\text { significant Ismaili presence in these } \\
\text { regions. }\end{array}$ \\
\hline AKAM (microfinance and microinsurance) & $\begin{array}{l}\text { The focus is on the regions of Mtwara and } \\
\text { Lindi, which are considered "ultra poor" } \\
\text { areas of Tanzania. There is no utilization of } \\
\text { these programs by Ismailis. }\end{array}$ \\
\hline $\begin{array}{l}\text { AKHS (Aga Khan Hospital, Medical } \\
\text { Health Centres) }\end{array}$ & $\begin{array}{l}\text { The Hospital is in Dar es Salaam. The } \\
\text { health clinics are in Arusha, Dodoma, } \\
\text { Iringa, Mbeya, Morogoro, Moshi, and } \\
\text { Mwanza. The health clinics are in } \\
\text { partnerships with the government to } \\
\text { provide maternal health and child } \\
\text { immunizations. The overall service is used } \\
\text { by the broader population in Tanzania with } \\
\text { the Ismaili community representing a very } \\
\text { small proportion. Also, individuals with } \\
\text { and without means may find other medical } \\
\text { services in Tanzania or elsewhere (e.g., } \\
\text { India has comprehensive and cheaper } \\
\text { services). }\end{array}$ \\
\hline
\end{tabular}




\begin{tabular}{|l|l|}
\hline Economic Component & \\
\hline Diamond Trust Bank & $\begin{array}{l}\text { The bank has branches in Dar es Salaam } \\
\text { and one in Arusha. These are for-profit } \\
\text { services and Ismailis do utilize services, } \\
\text { some individuals continue to do so out of a } \\
\text { sense of loyalty. However, there are now } \\
\text { more options for services and other } \\
\text { institutions are also utilized. }\end{array}$ \\
\hline Jubilee Insurance Group & $\begin{array}{l}\text { The headquarters is in Dar es Salaam and } \\
\text { there are branches in Mwanza, Arusha, } \\
\text { Mbeya and Zanzibar. }\end{array}$ \\
\hline Industrial Promotion Services & $\begin{array}{l}\text { Moshi Leather Industries Limited acquired } \\
\text { from the government in 1994, TLL Printing } \\
\text { \& Packaging Limited previously KIBO } \\
\text { Paper Industries Limited was acquired in } \\
\text { 1998. Individual Ismailis may be employed } \\
\text { or in leadership positions but the assets are } \\
\text { not community assets. }\end{array}$ \\
\hline Tourism Promotion Services & $\begin{array}{l}\text { Ten tourism properties in Tanzania. The } \\
\text { focus is on utilizing local products and } \\
\text { human resource development. Individual } \\
\text { Ismailis may be employed or in leadership } \\
\text { positions but the assets are not community } \\
\text { assets. Individual Ismailis with the means } \\
\text { may utilize services. }\end{array}$ \\
\hline $\begin{array}{l}\text { Mwananchi Communications Limited } \\
\text { (MCL) purchased in 2002. This is a for- } \\
\text { profit enterprise and the assets are not } \\
\text { community assets. }\end{array}$ \\
\hline
\end{tabular}

With the current development and growth of AKDN, there is a move in some ways to de-link or separate the Ismaili community from AKDN. This shift was described in a number of ways when discussing the connection of the Ismaili community to AKDN. The focus on being non-denominational positions the organization as not targeting a particular group and ensuring that the Ismaili community is not seen as being prioritized. The for-profit side of AKDN is focused on a broader market and in some cases is traded on the stock exchange, so linking with a specific community would be difficult. Thus, 
there is a need to establish a separation. For example, one senior AKDN representative pointed out that the various agreements of protocol should not be seen as privileging the Ismaili community, although acknowledging that the "backbone, the volunteers, [are] from the community" (interview 23). A senior member of the Hospital pointed to the focus now being on the national context, so there was now a new mandate and vision (interview 21).

This separation is not complete because of the history of the Ismaili community in the evolution of AKDN, and the continued involvement of individual Ismailis within the AKDN structure. As such, there is still a de facto attachment. There are formal and quasiformal mechanisms to link the community with components of AKDN. As discussed earlier, the Jamati committees and Chairs of AKES and AKHS have a connection with the Council. There is also an informal AKDN group that brings together the different components of AKDN leadership and includes the President of the National Council. This group was pointed to as being instrumental in addressing the need of the Ismaili community for affordable health insurance which was not being satisfied by their previous health insurance carrier, and a subsequent agreement being forged with Jubilee Insurance (a component of $\mathrm{AKDN}$ ) that was already providing insurance at an acceptable rate to AKDN employees (interview 23).

There is a regional AKF committee where all the Council Presidents of the region attend meetings. A senior governance executive of AKF, East Africa noted that AKF's work in the region is not with the Jamat but the Ummah in general and broader society. As such, it was important to have a link with the Jamat via the Council representatives to 
provide an understanding of the work of AKF. As well, it provided an opportunity for AKF to understand the Jamat's perspective (interview 29).

The potential for links between Council and AKF in other parts of the world was noted. An example was provided by a previous Council President who indicated that during his tenure funding for a family development project coordinator was unavailable, so a proposal was submitted to AKF Canada (according to his recollection) and the funding was approved (interview 23).

Some interviewees pointed to the tensions of having an organization that has moved to a broader mandate, but that still has a symbiotic as well as symbolic relationship with the core Ismaili community. For example, the Jamat as a group is targeted in surveys regarding the future direction and their satisfaction with the current structures of AKES schools, but the direction that may be deemed relevant for the Ismaili community may not be in step with the broader perspective (interview 25). Also, it was pointed out that the original rationale for AKES schools was to address issues of access within the Ismaili community. However, given the shift in the Ismaili population, there is no longer the same rationale for maintaining the number of schools. As well, there are now other options available, and Ismailis who have the financial means may opt to send their children to schools other than AKES. Other Ismailis may still feel a connection to AKES and see a need for AKES schools.

A senior member of AKHS pointed out that there is still an obligation to the Ismaili community, but it is part of a broader mandate. For example, the Hospital is now engaged more in providing health provisions to government employees, and the Hospital 
was described as being more open with the aim of becoming a national, regional and international entity (interview 21).

There were areas for improvement noted in the relationship between components of AKDN and Council. For example, there are various rebates from AKHS that are provided to the Council for Jamati needs and are beneficial in trying to manage the budget of the Council in the area of Health. However, in education, it was noted that there were rebates but now only credit facilitation is available. The change was attributed to potential conflict with other communities needing assistance and as such this benefit was lost (interview 19). The potential link with areas of AKDN that have a particular specialization such as micro-finance was pointed to as an area where AKDN and Council could facilitate more alignment. For example, it was noted that the priority for the microfinance programs is not the Ismaili community even though there is a need for such programs within the community (interview 19). The extent of the collaboration and where that line should be drawn is unresolved and differs depending on how the relationship between the Ismaili community and AKDN segments are perceived both internally and externally. As such, there is sometimes a disjointed articulation of the role of the Ismaili community vis-à-vis AKDN.

\section{Role of HH/AKDN as a Buffer/ Force-Field}

As discussed, the changing role of AKDN vis-à-vis the Ismaili community has been described as one where the mandate has evolved to focus on broader issues than specifically the needs of the Ismaili community. However, the role various components of $\mathrm{AKDN}$ and the $\mathrm{AKDN}$ resident representative may have as a potential buffer for 
Ismailis within Tanzania is important to consider. In addition, given the role different segments of AKDN play in the areas of health, education, and economic development, the capacity to bring stakeholders together and act as a "force-field" will be discussed.

The AKDN representative is in a way an intermediary position that helps facilitate the Imamat goals. As discussed, it plays that diplomatic role between AKDN entities and government and is involved in enhancing the links between AKDN agencies themselves.

The history of the Aga Khan institutions, especially in the area of health and education and its sense of connection to the Ismaili community continues today. This connection itself may in some ways create a potential buffer for the community. However, it may also create a potential limitation in terms of the perception regarding the work of AKDN. For example, an Executive Officer of AKF in Tanzania stated that " [...] while its [AKDN's] origins may be from the Ismaili community, it is not exclusive to the Ismaili community" (interview 28).

The agreements with multiple countries can in some ways act in a reinforcing way to elevate AKDN to a so-called "partner of choice" for international aid agencies (e.g., European Commission, DFID, USAID, CIDA among others) and private foundations (e.g., Gates Foundation, MasterCard Foundation among others) (interview 28).

The capacity for the Imamat to foster engagement on multiple fronts provides the basis for being able to take on that intermediary position. The logic of hybridity that emanates from the Imamat level allows for engagement with government, third-sector, donor agencies and private entities to be tailored and in turn resonate with a particular logic in place. This maximizes the capacity for bringing stakeholders together, receiving funding, and ensuring long-term sustainability. The way government aid agencies and 
foundations choose to distribute their funds either directly to governments or through an entity such as AKDN brings to the forefront issues of state sovereignty and decisionmaking regarding development choices. The way AKF specifically and AKDN more generally may navigate within the boundaries of state sovereignty, but at the same time benefit from direct support from bilateral, government and private foundations was described by a an AKF interviewee in Tanzania as such:

[...] most countries are trying to adhere to Paris declaration guidelines and commitments that promote sovereignty and decision-making of developing countries. [...] therefore, by virtue of agreements are channelling all their developing assistance directly to countries. Having said that, if you look at recent developments both in Tanzania and more so [...] Kenya, countries such as the UK are questioning that approach, and again because we have agreements and long-standing partnerships, the quality of our programs, arguably AKDN is seen as a partner of choice where governments aren't. [...] (interview 28)

Furthermore, the interviewee noted that AKDN's mandate is to look for innovative solutions, and this may allow for greater flexibility than perhaps government systems (ibid.). However, the agreements of protocols that are in place in Tanzania are also seen as a concrete demonstration of working within the articulated confines of national priorities. This intermediary position also comes into play when engaging on broader issues such as pluralism, governance, and enhancing the relationship between government and civil society in general. This in turn could be beneficial for the Ismaili community in fostering overall development goals.

\section{Overview of landscape NGO/third sector and government in Tanzania}

Kaiser (1996) in examining the Aga Khan health and education initiatives, argues that the "overall state/society relations before, during, and after ujamaa can be understood 
in terms of periodic and often simultaneous state/society cooperation, conflict, incorporation, disengagement, depending on government's view of the private for-profit and non-profit sectors at the time" (p. 11).

In 2007, AKDN engaged John Hopkins University to update their previous work on the civil society sector with a focus on Tanzania. This was to assist with AKDN's understanding of the civil society capabilities and challenges as they launched their own Civil Society program in eight countries including Tanzania. The historical background, size and scope of the sector, legal contexts in which civil society organizations operate, and the need to address issues such as taxation and government support were explored. As well, the work highlighted areas where the third sector had made an impact which included the areas of health, micro-finance, and human rights. The importance of having an enabling environment for civil society organizations and the need to acknowledge the different skills that civil society organizations and government bring to the areas of development was noted (AKDN, 2007d).

Jennings (2008) argues that it is important to understand the relationship of NGO's and the state in the context of changing international development paradigms. For example, he notes that during ujamaa there was strong control from the centre of government and many NGOs became as he describes them, "surrogates of the state," that in effect were part of undermining the very principles they sought to engender such as equity, equality and alleviating poverty (p. 198). According to Jennings (2008), during ujamaa the focus on the primacy of state in development was supported by a type of international consensus. Furthermore, he argues that changes in the development paradigm in the 1980's resulted in a diminished level of control on issues of development 
by countries such as Tanzania (p. 201). This allowed a space for NGO's to have greater freedom of voice and the capacity to criticize national and international organizations.

The capacity for NGO's to engage in aspects of so-called democratization of Africa was examined by Ndegwa (1996) in a comparative case study analysis. Although his study focuses on Kenya, he brings up an important finding that even when there is opportunity and capacity for NGO's to engage in issues of democratization, the inclination was not to push for political change. As such, a reliance on NGO's to push forward issues of democratization or changes in political developments may need reevaluation. Nonetheless, there may be a role for implicitly encouraging ideas of an enabling environment, and engaging with ideas of pluralism and democracy, as is the case with the Imamat level and AKDN initiatives. Finally, as argued by Kaiser (1996) and as will be demonstrated in the current case study, it is important to understand the international and regional context when examining the state-civil society relationship in Tanzania.

\section{Imamat/AKDN Link with Government and External Organizations}

The current AKDN links with government in Tanzania include the national level protocol agreements that focus on health, education and economic development. The Imamat level and the overall AKDN Committee play a pivotal role in understanding the transnational AKDN position in relation to national priorities. As discussed, there is a dedicated AKDN Representative office that manages the overall AKDN links with the government in Tanzania. However, each entity also engages with relevant Ministries on various technical issues and to varying degrees in the area of policy shaping. For example, 
a senior member of the AKHS management team noted links with government that included engaging in various government forums, providing health care to the public sector, internships for individuals from government hospitals as well as working with government to facilitate immunization programs (interview 21). As well, there are partnerships with government in providing expertise in the areas of primary health care. AKHS through its primary health centres was seen as being able to support government in providing maternal and child health services (interview 33). For example, the government provided vaccination supplies and the centres would administer the immunizations.

AKDN sectors both in the profit and non-profit segments were sought by government for their expertise on issues of regulation and overall policy direction. For example, in the area of insurance, providing input to regulators seeking to formulate new law or regulation was noted (interview 30). The need to be aware of the policy context both at a national and global level was seen as relevant to engage with government both in a responsive and proactive manner (interview 27). Relationships with all levels of government were seen as a way to garner support and build trust. For example, in the area of education, it was noted that relationships are built vertically and horizontally (interview 27). This would include the Ministry of Education, district and local levels and stakeholders within the school system (ibid.). The shift away from the national program in AKES schools was identified as diminishing the links with government. There is now an attempt to re-establish previous links by once again offering the national program (interview 25). In areas of professional development, there were opportunities for government institutions to engage with AKDN's expertise in health and education. One 
interviewee in the area of Health noted that their role is not as policy makers, but rather to provide government with advice and assistance in implementation (interview 22).

An interviewee from AKF highlighted the importance of engaging local government in areas of development. AKF was described as "an honest broker by partners, local government and [...] local communities" (interview 28). This was seen as enhancing AKF's ability to engage at the local level. As well, given the broad ranging mandate of AKF, the engagement in policy was described as follows:

[...] We [are] also at many times involved in policy making, so we are part of the stakeholders with all these Ministries [i.e., Education, Health and Agriculture]. When it comes to policy making and decision making, where they need our assistance, we [...] actually are sitting there to make those changes. (interview 29)

The long history of segments of AKDN in Tanzania and its involvement in health, education, and economic development have also led government to seek out AKDN to manage projects. However, it was noted that there are times when government requests go beyond its capacity, resources, and the mandate of AKDN (interview 23). One interviewee that was part of the AKES governance noted that the very scope of AKDN and its resources in multiple areas of expertise provide a benefit when seeking to engage with government on specific issues of relevance (interview 26).

\section{AKDN Regionalization}

Although the regional push of AKDN in East Africa may seem to be more of a recent phenomenon, this interest goes back to the 1950's and 1960's. Governments in East Africa at the time shared common regional development goals (AKDN, n.d, p. 2) and this push reinforced Aga Khan development interests in thinking about policies in education, 
health and finance from a similar regional perspective. However, in the 1970's different country realities in Kenya, Uganda and Tanzania decreased the regional momentum (ibid.). This tempered AKDN's concrete regional development goals, but the importance of thinking from a regional perspective continued. There has been a resurgence of government buy-in for a regional perspective again, especially with the move towards the establishment of the East African Union.

The move to a more regional approach is already part of the structure in some components of AKDN and others are moving in a regional direction as well. For example, one senior member of the management team of the Hospital in Tanzania noted the complexity of AKDN, but indicated that the emphasis on regional structures was a move in the right direction. Furthermore, this regional approach was seen as a way the Imamat level wanted to enhance empowerment at the field level (interview 21). Although there was no formal regional governance or management structure in place for the hospitals, there are two structures that encourage a regional perspective. This includes a regional strategic and planning committee and a CEO's forum (interview 21).

In the area of insurance, the regional approach was seen as having a number of advantages in creating a level of uniformity and standardized practices that allowed for minimizing costs (interview 30). There are local practices and laws that are taken into account, but having the capacity to regionalize aspects of insurance such as the capacity to undertake risk via reinsurance was seen as beneficial. The capacity to share information across the region and internationally in terms of best practices was also seen as highly valuable in the area of micro-insurance (interview 31). The Diamond Trust Bank was considered regional in scope with Kenya providing support and policy 
guidelines. The aim was described as creating a seamless banking structure in East Africa with similar products that are localized (interview 32).

$\mathrm{AKF}$ is the most regionally focused component and has a regional strategic outlook. It was anticipated that the areas of Health and Education would follow a similar path with more of a strategic regional vision (interview 23.). For example, there is now an East Africa Education committee within AKDN (interview 26).

Also, the Advanced Nursing Studies program has a team that oversees all campuses in East Africa. There are opportunities to share resources and for faculty to share experiences (interview 34). The Institute for Educational Development is operating on a regional basis, and it has students from Kenya, Uganda and Tanzania. A comprehensive regional Aga Khan University for East Africa is also in the planning and development stages.

The push to regionalization has not occurred without elements of resistance and difficulty. For example, in the area of post graduate medical education the aim was to develop on a regional basis with a vision of having interns from East African countries attend (interview 24). However, at the time of interviews, there was only one postgraduate medical program, and there was a sense of isolation from the other programs in Kenya. Also, as noted by senior member of AKES management, a regional approach was previously tried in the school context on a volunteer basis, but it did not get enough support (interview 25).

One area of tension in the regional emphasis noted by a few interviewees was the emphasis on Kenya taking the lead, and some components in Tanzania feeling like a satellite or affiliate rather than part of a regional effort. 
The implementation of an AKDN committee for East Africa was identified as a potential mechanism to enhance collaboration in the region. This would allow for examining policy making and decision-making for the region and ensuring there were no duplication of services (interview 29). The East African Union is still in its infancy, so its influence in terms of a regional approach to programs and services is still to be determined. As noted by a senior member of the governance structure of AKF, EA.

[...] [The] East Africa Union is [still] very new. So whenever you are talking to donors to your partners, you are still talking country-to-country, at the moment. You're not talking East Africa. Although we have [a] couple of programs which we are doing [...] everywhere in East Africa, they are very small and the funding is not that big. [...]. [There are] different stability, political, geographical, policy making, corruption issues and all kinds of issues which are coming in before they make a decision to where they want to actually put their money. [...] (interview 29)

There is also an international element that comes into play when examining Tanzania. AKU has an international scope of programs with mechanisms that allow for information exchange. There are connections with Karachi in the areas of educational development, nursing, and post-graduate medical education. There is also the potential for cross-continent research collaboration and faculty and student exchanges. Some exchanges with the faculty and senior level appointments are already occurring, especially given the experience and development of the AKU in Karachi. As well, recruitment of doctors and nurses from Karachi was another area identified. AKF in Karachi also provides support in the area of Rural Support programs. There are also many international partnerships of different segments of AKDN that are focused in the areas of health and education as well as equity partnering in areas of economic development. As well, the Imamat level in Agliemont provides a global perspective and guides coordination. 


\section{Conclusion}

Unlike Canada, where there is a level of state buttress in the area of welfare, this is minimal in Tanzania. The implications are difficult for those individual Ismailis who are facing issues of poverty, despite the progress made from an AKDN organizational perspective or by individual Ismailis. There are some programs geared to very poor populations (e.g., "ultra poor") in Tanzania. These programs focus on rural areas and are overseen by AKF and AKAM. They include programs in Southern Tanzania that focus on agricultural productivity and the various micro-finance and more recently microinsurance programs. However, these are very specific and targeted programs rather than what would be considered comprehensive social protection mechanisms. It goes back to issues of whether welfare is a rights based undertaking or one that is rooted in selfreliance and independence that harnesses the market to address welfare. Initially, issues of welfare were rooted in the Ismaili community as there was an inherent need for access because of racialized policies and lack of resources. However, in the current context, there has been a shift in demographics of Ismailis in Tanzania and increased options for those Ismailis with resources who may choose to opt in or out of AKDN based services. In addition, there is an increased constituency beyond the Ismaili community that underlines AKDN's new mandate and vision.

The Imamat level and to varying degrees components of AKDN are straddling multiple logics and multiple constituencies. However, at the same time, the community level where these structures began and in a sense owe their existence to, are experiencing signs of stress that are not being adequately addressed. As such, although the focus is on self-reliance and independence at both the community level and within AKDN 
components, there is a need to think about incorporating a more comprehensive sustainable mechanism for social protection.

To some extent, the potential for the Council for Canada to tap into state mechanisms and other external opportunities for poverty alleviation is not available in the Tanzanian context. The AKDN representative has taken over the role of engagement with the government, and by doing so may have inadvertently marginalized the Ismaili community vis-à-vis any potential direct links with the government. AKDN's capacity at various levels to engage with a mixed logic is not seamless. It is apparent that the real capacity for a logic of hybridity and the ability to blur the lines between sectors resides at the Imamat level. As well, because the precursors of AKDN were initially rooted in the community and to some extent were established as silos that provided expertise in different segments and sectors, the tensions that arise and issues regarding coordination are not surprising.

The link between the AKDN and the Ismaili community level continues in Tanzania, but there is a tension. As described in the case study, the strength of that connection is very much dependent on the engagement of individuals who hold positions within Council and AKHS and AKES. The impetus and rationale to have the needs of the community at the forefront are difficult with the limited Ismaili population. At the Council level, there is a level of frustration given the limited donated financial resources and trying to provide programs and services at the community level. Also, the AKDN profit-making entities have a different priority and agenda, and even the social segments are trying to meet long-term sustainability objectives and may have at the forefront surplus generation goals that are not conducive to an overall social protection framework. 
Furthermore, when AKDN links to an overall national direction (e.g., agreements of protocols), there is more of an incentive to ensure that the Ismaili community is not seen as being privileged. Usually, you have state decentralization to the community level and the possible negative effects of vulnerabilities going unaddressed. However, in this case we have communal structures that were the precursors to the broader based initiatives and some that still straddle the community level, yet community vulnerabilities persist. The vision may be that by focusing on self-reliance and independence as well as the obligations to the Imam in terms of service that any remaining vulnerabilities can be addressed at the community level. This assumes that strongly networked links exist at the community level be it local, national, or even regional. However, it could be argued that in the Ismaili context, that link in a sense is superseded by the Imamat level connection to the individual Ismaili vis-à-vis allegiance which may displace strong communal links. As well, the authority, vision, and direction are external to the community.

There is some potential for the Council structure in Tanzania to move out of its own sectoral confinements and link with regional resources. However, the infrastructure to do so is not yet in place. So although AKDN is moving forward with a regional strategic framework, the communal structures need to catch up. This may help address issues of vulnerability at the community level by taking advantage of a space that is above the community.

The overall AKDN development strategy is described as being in line with national development goals. However, this is not to suggest that there are strong links of co-production with government. Instead, there is engagement that is highly contained and structured, so the influence of government on the projects of AKDN is limited. As such, 
AKDN positions itself as being a catalyst or initiator in the areas of health, education, and economic development. As well, the transnational character of AKDN itself and the needs of the Network in different countries may result in specific national priorities being delayed or changed.

The focus on capacity building and long-term investment draws attention to the limited consideration to overall social protection that usually falls on the state, but it is not within the capacity of an entity such as AKDN to do so. This can result in important components of welfare relegated to targeted strategies versus a comprehensive social protection approach. 


\section{CHAPTER 6: CONCLUSION}

Experience around the world, in developed and developing countries, suggests that partnerships involving the government, the business sector, and the wide variety of institutions of civil society, have enormous potential for finding innovative solutions to the delivery of social services, and the development of a nation's human resources.

New institutions will emerge, and existing institutions can be improved and in some instances take on new areas of activity. Opportunities will develop to create capacity to look beyond the pressing concerns of the day, and to address problems that are chronic or emergent. ${ }^{21}$

Ideas about social welfare and sites of welfare production have been framed within a particular set of confines whereby there are identifiable sectors with a corresponding DNA or logic. In addition, there has been a tendency to focus on a statecentric formulation of welfare. An understanding that is framed with clearly delineated boundaries can initially be useful in studying a complex topic such as welfare production. However, it can also place limits on the questions we ask, and can in turn limit our capacity to fully understand how welfare is produced and where it can be delivered.

This dissertation has provided a more comprehensive framework of welfare production by examining configurations that are not confined to the usual state-market dynamic and that allow for incorporating multiple logics simultaneously. It also takes into account configurations that span regional and national boundaries. As well, the management and orchestration of welfare production is expanded to non-state entities.

The unique composition of the Ismaili Imamat, Ismaili community institutions

21 Speech by His Highness the Aga Khan Plenary Session: Conference on Indigenous Philanthropy Islamabad, Pakistan, 17 October 2000, Retrieved from http://www.akdn.org/Content/312 
and AKDN allows for an exploration of some interconnected social and economic segments that are often difficult to study simultaneously (i.e., state, market, third sector/civil society, religious communities) in the area of welfare production. This was demonstrated by the capacity of the Imamat level to incorporate multiple logics within its own DNA and engage stakeholders from diverse segments and scales. The idea of allegiance (i.e., Imam vis-à-vis Ismaili community member) transcends the confines of a particular state and demonstrates the capacity for welfare production to take place beyond a particular set of borders providing a new imagining of how welfare production may evolve. As with transnational networks, the transnational make-up of AKDN highlights the importance of sharing information, resources, exchanging ideas and creating synergies in the area of welfare production. It brings to the forefront an Imamat level that is not confined by a particular scale be it local, national or regional. However, the examination of both communal and broader initiatives highlights the tensions that may exist in the evolution of welfare structures.

Another area of focus in this dissertation was the concept of the "fourth position" poised by Fowler (2000). As discussed, it allows for the capacity to function in a space that is connected to aspects of state, market, civil society/third-sector, and community, but is not necessarily a part of those sectors. In essence, there is the ability to work above the entanglements of a particular sector. These aspects of blurring the lines between sectors, the capacity to be connected yet apart from the sectors, simultaneous logics, relaxing the state-market dynamic, and drawing on aspects of scale allows for an understanding of welfare that is more comprehensive (Molina, 2009; Evers, 2005; Gough, 2004; Mahon, 2003; Davis, 2001). 
The key question in this dissertation was not the role of the community in welfare production, although the community was the rationale for the services of the precursors to AKDN institutions. The key dynamic is the evolution of a cluster of transstate/international non-state institutions and the role the Imamat plays, particularly as a "force-field" that is not confined to the Ismaili community. The Imamat level is the pinnacle that rests above the Ismaili community, and is the ultimate decision-making authority for the Ismaili community and AKDN.

Given that the Imamat level encompasses the so-called "fourth position" (Fowler, 2000) of being connected to but not a part of one particular segment (i.e., state, market, civil society, community) and the AKDN is the mechanism that the Imamat utilizes to engage with various "sectors", the logic and constituency of AKDN itself has evolved. However, with this evolution, comes the responsibility for a broader mandate and a wider range of beneficiaries. This can create the potential for a disconnect between AKDN entities and the needs of members of the Ismaili community, especially individuals who are still in a tenuous position and have not yet achieved the expected levels of selfreliance and independence. Although there are expectations that the community level is ideally suited to resolve remaining vulnerabilities, this may not be the case. Differences in socio-economic status, levels of engagement at the community level, and an emphasis on individual independence and self-reliance can make resolving welfare issues at the community level difficult. It also brings into question the long-term implications of having entities such as AKDN engage in welfare without comprehensive co-production mechanisms as part of its relationship with the state. 
The next sections provide a summary of the main research findings and highlights the contributions of this research.

\section{Main Research Findings}

\section{Overall Organization of AKDN and Ismaili Institutions}

This study of the Ismaili Imamat, Ismaili community structures and AKDN in both a developed and developing world context at the international, national, regional, and local levels allowed for opening up the confinements of sectoral based thinking in welfare production. The comprehensive system of the Imamat level and its link with the Ismaili community via the Council and Board structure and the broader mechanisms of AKDN brings to light the potential and the complexity of engaging with a logic of hybridity.

The Imamat level has the capacity to see problems of development from a transnational perspective. The Ismaili community itself provides a strong basis for engagement in issues of welfare. The mandate of the Imam is framed as an obligation to ensure the security, quality of life, and provide spiritual guidance to his followers. The Imam's broader mandate is linked to overall economic and social development in the societies in which Ismailis live. The historical developments of welfare connected to the Ismaili community that is directed by the Imamat level highlighted the need to be engaged in welfare on multiple fronts for the community's survival. In essence, it is trying to take control of the sources of quality of life, especially given access to social provision has not always been the case. So the various components of the "welfare 
diamond" (state, market, family, community) can be articulated by bringing together the Ismaili Imamat, AKDN and Ismaili community institutions.

The strategic direction of the welfare mechanisms have been concentrated at the Imamat level, and the links between the Council and relevant Boards are ultimately responsible and accountable to the Imamat level rather than the community itself. This can create the potential for community input and the needs of the community not to be aligned with the direction of the Council and relevant Boards because their ultimate authority is the Imam. In the Ismaili community context, the idea of independence and self-reliance is tempered by a dependence on the Imamat level for direction in spiritual and material matters. As well, the Imamat institutions are in some ways dependent on the implementation resources of individual Ismailis. This connection based on allegiance and faith can make it difficult to separate the communal institutions and those that are now focused on a broader mandate.

The Ismaili community as a whole does not play an integral part in the vision and direction of $\mathrm{AKDN}$, although the origins and existence of AKDN are rooted in the Ismaili community and at one point the community may have been the main beneficiary of programs and services - (i.e., Health, Education, Banking and Insurance). This may result in the non-alignment of the needs of the Jamat in relation to other constituencies. There are individual Ismailis that work and volunteer in various capacities throughout AKDN including leadership and governance positions. However, to equate the individual Ismailis in these positions as necessarily representing the interest of the community as a whole is not the full picture. Although there are mechanisms in place to address the needs of the Ismaili community via Jamati committees within AKES and AKHS, broader 
constituency pressures can make this task difficult, especially in cases where the number of Ismailis has diminished (i.e., Tanzania). In terms of the profit-making entities of AKDN, there may be a sense of an obligation for assistance to the Ismaili community level, but this may not translate in financial terms. To some extent, mechanisms such as protocol agreements with governments and the need to attract a broader base for programs and services necessitates not being perceived as a community based organization.

The relationships at the Imamat level with leaders in both developed and developing countries creates a dynamic of legitimacy and authority that allows the Imamat to obtain certain privileges that enhance the capacity to venture into various nonprofit (i.e., "para-company") and for-profit ventures. This is achieved by setting the stage of what constitutes an enabling environment and in essence influencing the context in which it operates. For example, the Imamat level is capable of speaking the language of state, especially as it relates to creating diplomatic ties and agreements of protocol.

The capacity for co-production of welfare was another area that was identified as being important as a mechanism to reduce vulnerabilities as well as increase the sites where welfare production could take place. Although there were pockets of collaboration and engagement defined as public-private partnership, there was caution in the level of engagement. Engagement was more strategic and could be described as constrained cooperation. Thus, co-production with government was limited. There was a similar “arms length engagement", as expressed by Najam (2006) in studying the rural support programs of AKDN in Pakistan. There is a sense of wanting to have control over innovative development to ensure sustainability. Also, there is the possibility that high 
levels of connectivity with the state could derail long-term objectives at the office of Imamat level. Given that the Imamat level mandate is not confined to a particular sector or scale, it necessitates a level of engagement with issues of welfare that transcends national borders. So although there is a cordial relationship with government and framing AKDN priorities within the context of national priorities (i.e., protocol agreements), the relationship is tempered to ensure the objectives of the Imamat and AKDN stay front and centre.

The underpinning of self-reliance and independence in both the Ismaili community context and within AKDN components (i.e., profit and non-profit) seem to focus on ensuring access to the potential sources of well-being. Furthermore, the Imamat level's connection to various components of state, market, civil society/third sector and community increases the capacity to tap into a multitude of resources. This ensures longterm sustainability, and allows the Imamat level to take on an intermediary position and bring various stakeholders together on pressing issues of development. This includes engaging in the market with a long-term time horizon and acting as a catalyst for private sector endeavours that otherwise might not have been undertaken given the potential risks (interview 1).

Although the Imamat level may be occupying that intermediary space, the capacity for the mechanisms of the Imamat (i.e., AKDN) to also engage in a fully realized potential of a logic of hybridity is a more difficult proposition. The AKDN is a culmination of elements that began in the Ismaili community that has since evolved to meet the needs of a broader constituency. However, as discussed, the AKDN components are still evolving and the capacity to seamlessly engage in a logic of hybridity or not be 
confined to a particular sector or scale is still an ongoing process. For example, there can be tensions in trying to implement a multi-input area development approach when the synergies of the different components of AKDN are not fully realized. Also, there is the potential for an economic focus to overshadow social elements as may be the case in a surplus generation non-profit environment. Thus, even in a configuration that tries to balance the social and economic aspects, the Polyanyi conception of incorporating the market into collective and individual needs of society may be difficult. Furthermore, AKDN has components that are engaged in aspects of both decomodification and commodification, so the dual role of profit seeking and tempering the effects of the market can create areas of non-alignment. For example, in countries where the Ismaili population has diminished (i.e., Tanzania), there is a potential for a disconnect between AKDN entities and the needs of the Ismaili community, especially individuals with unresolved issues of vulnerability.

As discussed, the underlying aspect of both AKDN and Council and Board approaches is the concept of self-reliance and independence. These values may help propel individuals and the overall organizational components; however, it is important to consider the implications when a rights-based underpinning of welfare is not part of that configuration. For example, there is the potential that once a particular socio-economic standing is achieved by individuals within the community level the sense of attachment to overall community needs may diminish.

The next section provides a more in-depth comparison of key themes explored in the Canada and Tanzania case studies. 


\section{Comparison of Canadian and Tanzanian Key Themes}

Engagement with the market to secure financial stability and in turn self-reliance and independence is key to ensuring the welfare needs of the Ismaili community are met. The welfare programs and services at the community level act as a buffer for community members that are unable to meet their needs. Other services and programs supplement state or other external programs. However, when ideals of self-reliance and independence are not fully realized it can stretch the capacity of the communal based welfare mechanisms. The dependence on community donor funding for programs and services and a high level of expectation coupled with not wanting to be seen as being dependent on the state can further stretch the capacity of the community welfare structures. As the resources for programs and services are donor based, it points to the issue of sustainability and willingness to participate should the community level not be as networked and linked as expected. This draws attention to the fact that even in a community context, the capacity to work together for collective needs in order to temper the effects of the market, as argued by Polyanyi, can be difficult. For example, a topdown approach to programs and services was described by some interviewees in Canada rather than having a more broader based community level engagement. In Tanzania, the number of individuals that have the resources to contribute to community programs and services has diminished. These factors can result in non-alignment between the needs at the community level and the available programs and services.

The programs and services that constituted the precursors of AKDN during the colonial period in East Africa filled a much-needed gap for the Ismaili community, and it 
was a source of maintaining strong links within the community level. As well, it reinforced the role of the Imam as the individual ensuring the quality of life of his followers. These services initially acted as a mechanism for Ismailis to engage with the market and seek educational opportunities to enhance their options. This boded well for many, and it also provided necessary skills and a sense of self-reliance and independence should migration either because of threat (i.e., Uganda 1970's) or need (i.e., to expand economic or educational options) become necessary. The move of Ismailis out of Tanzania, beginning in the 1960's-1970's, and the decline of the Ismaili community in that country, has seen the mandate of AKDN move beyond this core group. The headway of the AKDN today in Tanzania beyond the community level is a testament to the strategic direction of the Imamat level, and the capacity to engage at multiple levels simultaneously. As well, AKDN in East Africa is taking more of a regional approach to development. This trajectory and growth is not without tensions. The Ismaili community level in Tanzania is facing limitations in its capacity to fund the relevant programs and services, and AKDN entities that straddle the broader goals and those of the community can have conflicting priorities.

The development of Ismaili community in Canada is also grounded in the idea of self-reliance and independence. This was the anchor that helped ensure the successful migration of Ismailis during times of crises (i.e., Uganda in 1970's and 1990's from Afghanistan) and at other times from various countries. In the early period, there was a need for close links within the community, and this most likely necessitated reciprocity and mutual assistance. As well, there tended to be more of a similar background of experiences and level of socio-economic stability (e.g., Ismailis were forced to leave their 
assets behind after their expulsion from Uganda). As the number of Ismailis in Canada increased, a more concrete infrastructure of a Council and Boards under the direction of the Imam came into play. There are also differences in socio-economic status, cultural backgrounds, and differences in levels of engagement that can strain the capacity of community institutions.

A comparison of some key themes explored in this dissertation is presented in the table below.

Table 6-8 Comparison of Key Themes - Canada and Tanzania ${ }^{22}$

\begin{tabular}{|c|c|c|}
\hline Key Themes & Canada & Tanzania \\
\hline $\begin{array}{l}\text { Mobility/Immigration } \\
\text { of the Ismaili } \\
\text { community and } \\
\text { Changing } \\
\text { Demographics }\end{array}$ & $\begin{array}{l}\text { - } 1950 \text { 's-1990's Ismailis in } \\
\text { Canada were } \\
\text { predominately from South } \\
\text { Africa, East Africa, (1972 } \\
\text { Ismaili expulsion from } \\
\text { Uganda) Pakistan and } \\
\text { India. This population } \\
\text { represented Khoja } \\
\text { Ismails. } \\
\text { In the 1990's, } \\
\text { deteriorating conditions in } \\
\text { Afghanistan led to } \\
\text { migration of Ismailis from } \\
\text { the region. This resulted } \\
\text { in a change of the cultural } \\
\text { makeup within the Jamat. } \\
\text { The Ismaili population in } \\
\text { 1975 was estimated at } \\
\text { 10,000. In 2011, the } \\
\text { population was estimated } \\
\text { between 70,000-80,000. }\end{array}$ & $\begin{array}{l}\text { - Ismailis first came to } \\
\text { Zanzibar in the mid-19 } \\
\text { century from western India. } \\
\text { The height of the Ismaili } \\
\text { population in Tanzania was } \\
\text { in the } 1960 \text { 's. It is estimated } \\
\text { that before } 1971 \text { (the } \\
\text { beginning of nationalization } \\
\text { campaign was in 1967) there } \\
\text { were approximately twenty- } \\
\text { five thousand Ismailis living } \\
\text { in Tanzania. } \\
\text { However, by } 1995 \text { only } \\
\text { about four thousand Ismailis } \\
\text { remained. At the time of } \\
\text { interviews this number has } \\
\text { further decreased. }\end{array}$ \\
\hline
\end{tabular}

${ }^{22}$ Given the scope of the structure and governance of the Council and Boards as well as AKDN, I have not included these sections in the table. Instead, a verbal summary within the body of the chapter is provided. 


\begin{tabular}{|c|c|c|}
\hline $\begin{array}{l}\text { Authority of the } \\
\text { Imam }\end{array}$ & $\begin{array}{l}\text { - The Imam has "an } \\
\text { absolute and unfettered } \\
\text { power and authority with } \\
\text { respect to religious and } \\
\text { Jamati matters of the } \\
\text { Ismailis". The link to the } \\
\text { community is based on } \\
\text { allegiance. Council and } \\
\text { Boards are accountable to } \\
\text { the Imam above the } \\
\text { Jamat. } \\
\text { There are opportunities to } \\
\text { share ideas with the Imam } \\
\text { regarding programs and } \\
\text { direction. } \\
\text { The extent of engagement } \\
\text { was seen as contingent on } \\
\text { the capacity of the } \\
\text { Council and Boards to } \\
\text { harness relevant } \\
\text { information from the } \\
\text { Jamat. }\end{array}$ & $\begin{array}{l}\text { - As in the Canadian case } \\
\text { study, the Imam plays a } \\
\text { significant role in the } \\
\text { substantive policy direction } \\
\text { for Council and Boards. } \\
\text { There is room for dialogue } \\
\text { in terms of direction of } \\
\text { programs and services, but it } \\
\text { is tempered by the role of } \\
\text { the GRB in auditing } \\
\text { programs and services. } \\
\text { Also, the role Aiglemont } \\
\text { (the secretariat of the } \\
\text { Imamat) has on influencing } \\
\text { decision making at the } \\
\text { Council level is closely } \\
\text { linked to the budget } \\
\text { approval process. }\end{array}$ \\
\hline $\begin{array}{l}\text { Council and Other } \\
\text { Bodies } \\
\text { - Rationale for } \\
\text { Ismaili } \\
\text { Community } \\
\text { services } \\
\text { - Funding and } \\
\text { Redistribution } \\
\text { - Links with other } \\
\text { Council's } \\
\text { regionally and } \\
\text { internationally } \\
\text { Links with } \\
\text { government and } \\
\text { external } \\
\text { organizations } \\
\text { Challenges }\end{array}$ & $\begin{array}{l}\text { - There are more options in } \\
\text { Canada with state level } \\
\text { welfare services. } \\
\text { - Self-reliance, } \\
\text { independence and not } \\
\text { wanting to rely on the } \\
\text { state or external services } \\
\text { is a key rationale for } \\
\text { services. } \\
\text { Volunteerism is a key } \\
\text { driving force for } \\
\text { programs and services } \\
\text { both in Canada and } \\
\text { Tanzania } \\
\text { Compared to Tanzania } \\
\text { there is a high level of } \\
\text { professionalization in } \\
\text { Canada, and the capacity } \\
\text { of Council and the Boards } \\
\text { is more robust. }\end{array}$ & $\begin{array}{l}\text { - The initial rationale for } \\
\text { services were linked to the } \\
\text { colonial period when access } \\
\text { to health, education and } \\
\text { economic opportunities } \\
\text { were unavailable. } \\
\text { There is now a configuration } \\
\text { in the area of Health and } \\
\text { Education where these } \\
\text { components straddle the } \\
\text { community level and the } \\
\text { broader AKDN. } \\
\text { The issue of self-reliance } \\
\text { and independence are also } \\
\text { important in Tanzania, but a } \\
\text { greater proportion of the } \\
\text { Jamat is in need of } \\
\text { assistance making this } \\
\text { difficult to realize. }\end{array}$ \\
\hline
\end{tabular}




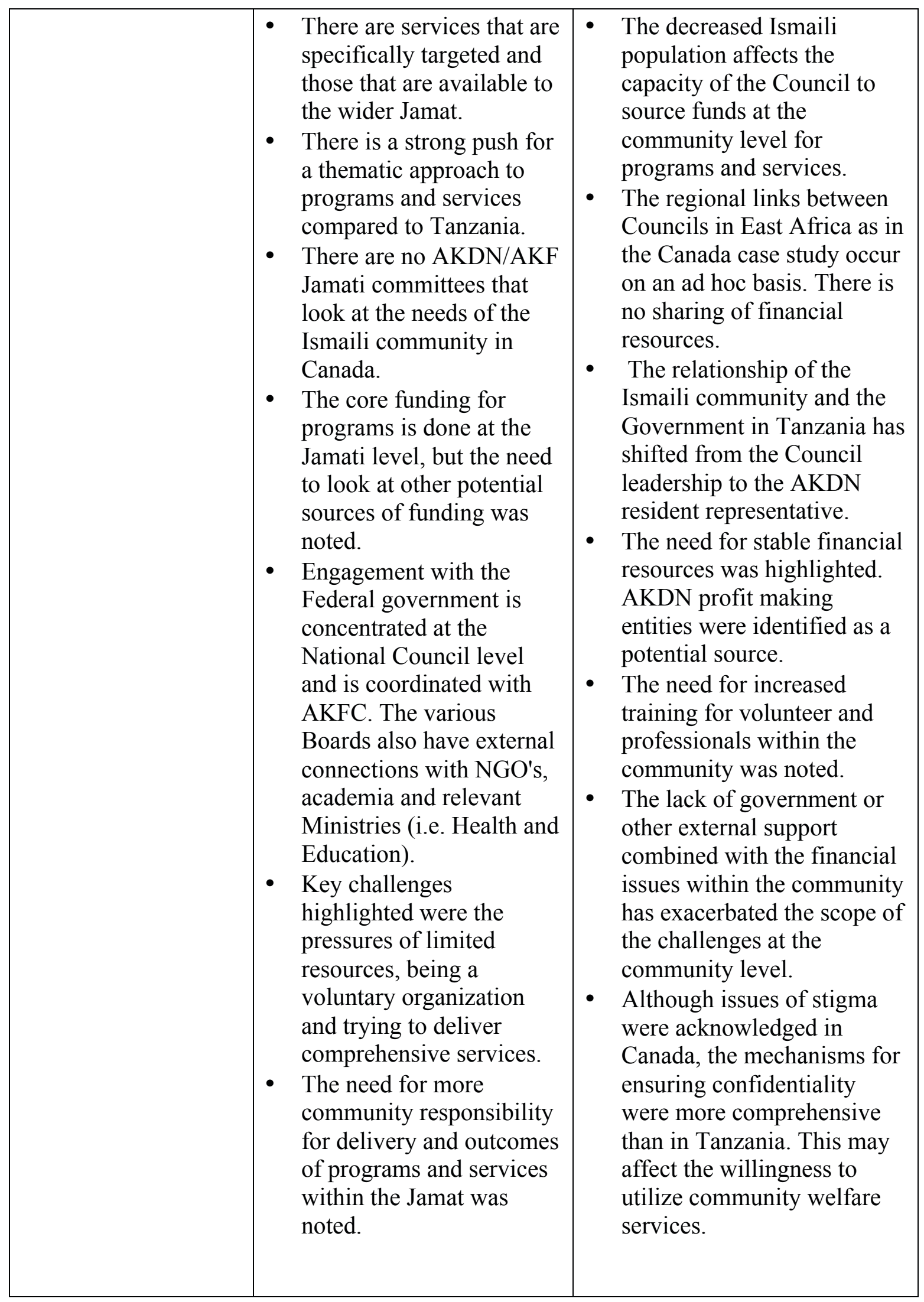




\begin{tabular}{|c|c|c|}
\hline & $\begin{array}{l}\text { The greater need for } \\
\text { grassroots consultation to } \\
\text { understand the needs of } \\
\text { beneficiaries within the } \\
\text { Jamat and ask how } \\
\text { Council and the Boards } \\
\text { can provide support was } \\
\text { highlighted. } \\
\text { Continuing to work on } \\
\text { leadership representation } \\
\text { was seen as important. }\end{array}$ & \\
\hline $\begin{array}{l}\text { AKDN } \\
\text { - } \text { Rationale for } \\
\text { AKDN } \\
\text { components } \\
\text { - } \text { Funding } \\
\text { - } \text { Challenges }\end{array}$ & $\begin{array}{l}\text { The focus of AKFC is on } \\
\text { programs for developing } \\
\text { countries and generating } \\
\text { resources. Also, raising } \\
\text { awareness and } \\
\text { researching issues of } \\
\text { development. } \\
\text { AKFC plays an } \\
\text { intermediary role between } \\
\text { resources (i.e. financial, } \\
\text { intellectual, volunteer) } \\
\text { and programs in } \\
\text { developing countries (i.e., } \\
\text { Tanzania). } \\
\text { There is a limited } \\
\text { AKFED presence in } \\
\text { Canada as the potential } \\
\text { for growth is in } \\
\text { developing and } \\
\text { transitioning countries. } \\
\text { The funding includes the } \\
\text { Aga Khan (for } \\
\text { administrative costs) } \\
\text { CIDA, private entities } \\
\text { (i.e. MasterCard } \\
\text { Foundation), the Ismaili } \\
\text { community, and the } \\
\text { general Canadian } \\
\text { population (i.e. World } \\
\text { Partnership Walk } \\
\text { Fundraiser). } \\
\text { Continuing to address } \\
\text { issues of collaboration } \\
\text { between other AKF's and }\end{array}$ & $\begin{array}{l}\text { - AKDN entities have evolved } \\
\text { and the rationale is now } \\
\text { focused on the broader } \\
\text { development goals in } \\
\text { Tanzania. } \\
\text { This is re-enforced by the } \\
\text { formal protocol agreements } \\
\text { with the government. } \\
\text { The AKDN components in } \\
\text { Tanzania include AKES } \\
\text { (nursery, primary, secondary } \\
\text { education), AKHS (Hospital } \\
\text { and health clinics), AKF } \\
\text { (focus on "ultra poor" } \\
\text { populations), AKU (post } \\
\text { graduate medical education, } \\
\text { advanced nursing education, } \\
\text { educational development), } \\
\text { AKAM (insurance and } \\
\text { micro-finance) } \\
\text { AKFED (banking, } \\
\text { insurance, media, tourism, } \\
\text { industrial promotion). } \\
\text { The funding depends on the } \\
\text { entity type. For example, } \\
\text { AKFED entities are similar } \\
\text { to other private enterprise } \\
\text { (i.e., investment and profits), } \\
\text { AKF is a combination of } \\
\text { donor, private and other } \\
\text { AKF entities in developed } \\
\text { countries. AKHS and AKES } \\
\text { included funding from } \\
\text { Imamat level (i.e. capital }\end{array}$ \\
\hline
\end{tabular}




\begin{tabular}{|c|c|c|}
\hline & $\begin{array}{l}\text { AKDN entities was seen } \\
\text { as an ongoing process and } \\
\text { context specific. } \\
\text { The sharing of expertise } \\
\text { between AKFC and the } \\
\text { Ismaili community } \\
\text { institutions may be an } \\
\text { area for re-evaluation. }\end{array}$ & $\begin{array}{l}\text { assets) and user fees. AKU } \\
\text { components include user } \\
\text { fees, subsidization, } \\
\text { sponsoring agencies. } \\
\text { AKDN is comprised of } \\
\text { diverse entities, but some } \\
\text { key challenges included } \\
\text { issues of coordination (i.e. } \\
\text { maximizing synergies } \\
\text { between entities), complex } \\
\text { reporting lines (i.e. local, } \\
\text { national, regional and } \\
\text { global). Also, the pace of the } \\
\text { growth and trajectory of } \\
\text { AKDN can be a challenge. }\end{array}$ \\
\hline $\begin{array}{l}\text { Ismaili Community } \\
\text { vis-à-vis AKDN }\end{array}$ & $\begin{array}{l}\text { The point of contact in } \\
\text { Canada for AKDN is } \\
\text { AKFC for the Ismaili } \\
\text { community. } \\
\text { The Ismaili community is } \\
\text { depended on for } \\
\text { intellectual, volunteer and } \\
\text { financial support. } \\
\text { AKFC does not deliver } \\
\text { programs and services in } \\
\text { Canada, but there was } \\
\text { some indication that there } \\
\text { could be more systematic } \\
\text { sharing of information } \\
\text { and expertise by AKFC } \\
\text { and other AKDN entities } \\
\text { in areas that are of } \\
\text { relevance to the Ismaili } \\
\text { community in Canada } \\
\text { (i.e., poverty alleviation, } \\
\text { micro-finance and early } \\
\text { childhood education } \\
\text { experts). }\end{array}$ & $\begin{array}{l}\text { - Some interviewees pointed } \\
\text { to the tensions of having an } \\
\text { organization that has moved } \\
\text { to a broader mandate, but } \\
\text { that still has a symbiotic and } \\
\text { symbolic relationship with } \\
\text { the core Ismaili community. } \\
\text { - Given the Central } \\
\text { Institutions of AKES and } \\
\text { AKHS straddle both the } \\
\text { community and the overall } \\
\text { AKDN structure, it can } \\
\text { create the potential for non- } \\
\text { alignment between the needs } \\
\text { of the core Ismaili } \\
\text { community and the broader } \\
\text { mandate. } \\
\text { The AKDN continues to } \\
\text { rely on individual Ismailis } \\
\text { as volunteers in governance } \\
\text { and other leadership } \\
\text { positions for AKDN entities. }\end{array}$ \\
\hline $\begin{array}{l}\text { Role of } \mathrm{HH} / \mathrm{AKDN} \text { as } \\
\text { a buffer }\end{array}$ & $\begin{array}{l}\text { The Aga Khan has been } \\
\text { central to ensuring the } \\
\text { assistance to Ismailis } \\
\text { during times of crisis. } \\
\text { AKFC and FOCUS have } \\
\text { also provided support to } \\
\text { the Ismaili community. }\end{array}$ & $\begin{array}{l}\text { There are formal agreements } \\
\text { of protocols in place in } \\
\text { Tanzania. } \\
\text { There is an AKDN resident } \\
\text { representative that plays a } \\
\text { diplomatic role between } \\
\text { AKDN entities and }\end{array}$ \\
\hline
\end{tabular}




\begin{tabular}{|c|c|c|}
\hline & $\begin{array}{l}\text { - AKFC is a point of } \\
\text { contact for leveraging } \\
\text { state and FOCUS acted as } \\
\text { guarantor for Ismailis } \\
\text { migrating to Canada from } \\
\text { Afghanistan. } \\
\text { The Delegation of the } \\
\text { Ismaili Imamat (DII), the } \\
\text { partnership with the } \\
\text { Government of Canada in } \\
\text { the Global Centre for } \\
\text { Pluralism (GCP) as well } \\
\text { as the upcoming Aga } \\
\text { Khan Museum in Toronto } \\
\text { are symbols for creating } \\
\text { visible links and in some } \\
\text { ways a demonstration of } \\
\text { self-reliance and } \\
\text { independence. }\end{array}$ & $\begin{array}{l}\text { government and is involved } \\
\text { in enhancing the links } \\
\text { between AKDN agencies } \\
\text { themselves. } \\
\text { - The history of the Aga Khan } \\
\text { institutions, especially in the } \\
\text { area of health and education } \\
\text { and its sense of connection } \\
\text { to the Ismaili community } \\
\text { continues today. }\end{array}$ \\
\hline $\begin{array}{l}\text { Imamat/AKDN link } \\
\text { with Government and } \\
\text { External } \\
\text { Organizations }\end{array}$ & $\begin{array}{l}\text { - } \text { Ongoing twenty-five year } \\
\text { relationship between } \\
\text { AKFC and CIDA. } \\
\text { High-level government } \\
\text { links exist between the } \\
\text { Imamat level and the } \\
\text { Prime Minister's Office as } \\
\text { well as the Minister of } \\
\text { International Cooperation } \\
\text { and Development. } \\
\text { There are no agreements } \\
\text { of protocol federally, but } \\
\text { more recently the } \\
\text { Government of Alberta } \\
\text { (in 2012) was the first } \\
\text { province in Canada to } \\
\text { sign an Agreement of } \\
\text { Cooperation with the } \\
\text { Ismaili Imamat. } \\
\text { GCP (focus is on research } \\
\text { and dissemination of } \\
\text { information on plural } \\
\text { societies) is an initiative } \\
\text { of His Highness and the } \\
\text { Government of Canada. }\end{array}$ & $\begin{array}{l}\text { - The current AKDN links } \\
\text { with government in } \\
\text { Tanzania include the } \\
\text { National level protocol } \\
\text { agreements that focus on } \\
\text { health, education, and } \\
\text { economic development. } \\
\text { There is a dedicated AKDN } \\
\text { Representative office that } \\
\text { manages the overall AKDN } \\
\text { links with the government in } \\
\text { Tanzania. However, each } \\
\text { entity also engages with } \\
\text { relevant Ministries of } \\
\text { government on various } \\
\text { technical issues and to } \\
\text { varying degrees in the area } \\
\text { of policy shaping. } \\
\text { AKDN technical expertise is } \\
\text { also sought by government } \\
\text { in the areas of health, } \\
\text { education and economic } \\
\text { development. }\end{array}$ \\
\hline
\end{tabular}




\begin{tabular}{|c|c|c|}
\hline & $\begin{array}{l}\text { DII is the Imam's } \\
\text { representation in Canada } \\
\text { located in the midst of } \\
\text { other embassies in } \\
\text { Ottawa. }\end{array}$ & $\begin{array}{l}\text { Although there were pockets } \\
\text { of collaboration and } \\
\text { engagement defined as } \\
\text { public-private partnership, } \\
\text { there was caution in the } \\
\text { level of engagement. } \\
\text { Engagement was more } \\
\text { strategic and could be } \\
\text { described as constrained } \\
\text { cooperation. }\end{array}$ \\
\hline $\begin{array}{l}\text { AKDN } \\
\text { regionalization }\end{array}$ & $\begin{array}{l}\text { The work of AKFC is } \\
\text { moving in a regional } \\
\text { direction in the area of } \\
\text { international } \\
\text { development. } \\
\text { - However, the sources of } \\
\text { funding from donors } \\
\text { continue to be } \\
\text { concentrated in a country- } \\
\text { to-country approach. } \\
\text { There is some potential } \\
\text { for donors i.e. CIDA to } \\
\text { consider regional } \\
\text { arrangements. }\end{array}$ & $\begin{array}{l}\text { - The regional push of } \\
\text { Imamat Institutions in East } \\
\text { Africa goes back to the } \\
1950 \text { 's and } 1960 \text { 's, but } \\
\text { different country focus in } \\
\text { the } 1970 \text { 's led to a pause in } \\
\text { regional thinking. } \\
\text { - AKF is the most regionally } \\
\text { focused and has a regional } \\
\text { strategic outlook. It was } \\
\text { anticipated that the areas of } \\
\text { Health and Education would } \\
\text { follow a similar path with } \\
\text { more of a strategic regional } \\
\text { vision. }\end{array}$ \\
\hline
\end{tabular}

As discussed, the system for programs and services both at the community and AKDN level are ultimately directed by the Imamat level. The links between the Ismaili community in Canada and AKFC are interesting. Although there is a dependence on the Ismaili community in Canada for financial and volunteer resources for AKFC initiatives, there is no sustained reciprocal engagement from $\mathrm{AKFC}$ to provide programs and services at the community level. Instead, AKFC acts more as a potential buffer and a useful connection for engagement with government in Canada. As well, engagement with broader based structures that focus on diplomacy, research and idea dissemination such as the DII and GCP may serve to address overall developmental goals that may 
tangentially benefit the Ismaili community. Other entities such as FOCUS can be instrumental during times of crises and when there is a need for relocation of Ismaili populations.

The trajectory and growth of AKDN components in Tanzania necessitates a focus on broader constituencies. However, in order to continue to be relevant to the initial Ismaili community in Tanzania, there may be need for more coordination between the broader based AKDN institutions and communal institutions. Given that the strategic direction takes place at the Imamat level and it is functioning as a "fourth position", the push for a re-evaluation of the levels of coordination may reside at that level. The coordination bodies that would be relevant include the AKDN Committee, AKF, Geneva and the Department of Jamati Institutions. However, the need for simultaneous engagement at the community level and ensuring that the Council and Board entities are aligned with the grassroots needs of the community is also important.

Overall the focus on self-reliance and independence along with the guidance of the Imam (i.e., types of business ventures to pursue, education in professional careers, having a strong command of the English language etc.) has helped to propel many within the community to a level of economic self-sufficiency. However, there remain socioeconomic differences within the community level and issues of stigma can hamper the willingness to seek welfare assistance.

At the community level, there is the potential for innovation and breaking out of its sector confinement. As discussed in the theory chapter, the ability to negotiate scales and the capacity for a logic of hybridity may serve to achieve more comprehensive welfare mechanisms. For example, the potential for engaging state and other external 
entities within the Canadian context is starting to take place in a more strategic manner at the Ismaili community level. However, the extent to which these links are tapped into will be determined by the capacity to see the community level not as fixed, but having the capacity to shift and engage with state, market and other civil society/third sector components in a more comprehensive manner. As well, looking at aspects of quality of life in a more of a thematic way further serves to expand the understanding of welfare as encompassing multiple aspects simultaneously. In Tanzania, the need perhaps for services that are more resource stable and are not reliant on ongoing donations from an already resource-strapped community may be something that needs further consideration. Also, the focus on a regional perspective as has been the case with AKDN may be useful for the community level to explore. This is especially important in Tanzania where the potential for collaboration with AKDN may be difficult given the small numbers of Ismailis that remain. Thus, there is a need to explore linking Councils more systematically and comprehensively on a regional and international basis by examining possibilities for information sharing and redistribution of resources.

\section{Contributions of the Research}

This dissertation explores an unusual configuration of welfare production that allows for a more comprehensive understanding of the key aspects related to the rationale, scope, and engagement in social welfare. It contributes to the research on welfare production by providing a broader understanding of the usually fixed segments of state, market, civil society, and community. As well, it allows for an understanding of multiple scales of engagement in both a developed and developing world context. 
This study examined the Ismaili Imamat, Ismaili community institutions, and AKDN as a microcosm of welfare production, where we find a logic of hybridity at the Imamat level. It helps us to understand that producing health, education, and engaging in economic development is not a linear, one segment endeavour, but is dynamic and has the capacity for change. However, the capacity for the various sectors to break out of their sector confinement may occur to varying degrees of success. For example, we see the AKDN as a mechanism of the office of Imamat with its initial connection to the Ismaili community, and now moving to a broader mandate and taking on multiple logics. However, the capacity to engage in a seamless manner or as described in a multi-input development approach is not without difficulty. This is because there is the potential to be trapped by the expectation of a particular sector, and address issues such as welfare from a narrow perspective (i.e., predominately an economic lens).

The interconnectedness of the various components of welfare goes beyond a zerosum understanding. It is not stuck in articulating a position that if civil society/third sector is involved in welfare provision then the state or another segment is necessarily less involved. It also draws attention to the capacity for entities other than the state to engage in the management and orchestration of welfare production. A zero-sum composition of welfare assumes a clear distinction between sectors, and that the logic of various sectors is fixed/immutable. The capacity to move beyond the confines of a particular sector requires seeing its logic not as fixed, but rather having the capacity to evolve and change into a configuration that meets the demands of complex issue like welfare production. However, at different phases of its evolution, the capacity to tap into multiple segments or scales may vary. This highlights the point that the realm of 
possibilities of what is expected from a particular sector can be prematurely limited if there is a high level of attachment to the logic of that particular sector. For example, the non-profit sector does not necessarily have at the forefront self-sufficiency, and models like a "para-company" framework (i.e. resource generation and surplus) are not usually at the core of how to engage with aspects of service delivery.

There will always be vulnerabilities in welfare production, whether by state, market, or civil society/third sector, so there is a need for more interconnections to mitigate the insufficiencies of other "segments" that have varying abilities to incorporate multiple logics simultaneously. Perhaps, it is by trying to create a cluster of institutions with the capacity for hybrid logics that the Imamat level is trying to enable engagement on a multi-input basis because issues of capacity and poverty alleviation are not social problems that can be tackled from a specific logic or scale.

The idea of blurring the sectoral divide and the capacity to be connected to a particular sector but separate from it, and the potential for a more dynamic logic of sectors (Molina, 2009; Evers, 2005; Fowler, 2000) requires further examination. This capacity may clearly reside with an identifiable entity as was the case with the Ismaili Imamat or it may be more dispersed, as we saw glimpses of this capacity within AKDN institutions and the Ismaili community context. As well, a more systematic examination of levels of co-production and an identification of a continuum of engagement by isolating potential factors that may foster different forms of co-production is needed. Further understanding of the vulnerabilities in play within different configurations of welfare and the extent to which different mixes can help mitigate vulnerabilities are also important. The focus is usually examining state downloading of welfare rather than the 
implications of scaling up and the potential blind spots that may occur. As such, there is a need for further examination of the new and persistent vulnerabilities that may result when moving from community to broad scale initiatives. Examining the complexity of the idea of community itself is another area that needs further study. For example, within the Ismaili community there are differences in socio-economic status and changing demographics from one that tended to be Khoja centric to one that is being tested and coaxed into broadening its scope with Ismailis from other parts of the world like Afghanistan migrating to countries such as Canada.

This dissertation highlights the idea that the capacity for innovation in the area of welfare production depends on the ability to break away from sector confinements as well as expand thinking in terms of what is a traditional sector and at what scale we can expect welfare production to take place. The importance of a hybridity in approach is underlined by the complex nature of social provision itself. For researchers in the area of social provision, it highlights the need to ask how research questions are framed in order to try and fully understand the dynamics at play in the area of welfare production. The composition of the Ismaili Imamat, Ismaili community and AKDN institutions may be unique, but the ability to provide new lines of inquiry for other configurations of social provision is no less important. For example, as communities, nations, and states evolve, so too must the recognition that the rationale, scope, sites of welfare production, and types of engagement also evolve. 


\section{INTERVIEW LIST}

\begin{tabular}{|c|c|}
\hline Interview 1 & $\begin{array}{l}\text { General Manager, Aga Khan Foundation, Geneva } \\
\text { Deputy Chairman of the Board, Aga Khan Development Network } \\
\text { (AKDN) }\end{array}$ \\
\hline Interview 2 & Director of Operations, Aga Khan Foundation Canada \\
\hline Interview 3 & CEO, Aga Khan Foundation Canada \\
\hline Interview 4 & $\begin{array}{l}\text { Senior Executive, His Highness Prince Aga Khan Shia Imami Ismaili } \\
\text { National Council for Canada }\end{array}$ \\
\hline Interview 5 & $\begin{array}{l}\text { Former Senior Executive, His Highness Prince Aga Khan Shia Imami } \\
\text { Ismaili National Council for Canada }\end{array}$ \\
\hline Interview 6 & $\begin{array}{l}\text { Senior Executive, His Highness Prince Aga Khan Shia Imami Ismaili } \\
\text { National Council for Canada }\end{array}$ \\
\hline Interview 8 & $\begin{array}{l}\text { Member, His Highness Prince Aga Khan Shia Imami Ismaili National } \\
\text { Board/Portfolio for Canada* }\end{array}$ \\
\hline Interview 9 & $\begin{array}{l}\text { Senior Member, His Highness Prince Aga Khan Shia Imami Ismaili } \\
\text { National Board/Portfolio for Canada }\end{array}$ \\
\hline Interview 10 & $\begin{array}{l}\text { Senior Member, His Highness Prince Aga Khan Shia Imami Ismaili } \\
\text { National Board/Portfolio for Canada }\end{array}$ \\
\hline Interview 11 & $\begin{array}{l}\text { Senior Member, His Highness Prince Aga Khan Shia Imami Ismaili } \\
\text { National Board/Portfolio for Canada }\end{array}$ \\
\hline Interview 12 & $\begin{array}{l}\text { Senior Member, His Highness Prince Aga Khan Shia Imami Ismaili } \\
\text { National Board/Portfolio for Canada }\end{array}$ \\
\hline Interview 13 & $\begin{array}{l}\text { Senior Member, His Highness Prince Aga Khan Shia Imami Ismaili } \\
\text { National Board/Portfolio for Canada }\end{array}$ \\
\hline Interview 14 & $\begin{array}{l}\text { Senior Member, His Highness Prince Aga Khan Shia Imami Ismaili } \\
\text { National Board/Portfolio for Canada }\end{array}$ \\
\hline Interview 15 & $\begin{array}{l}\text { Senior Member, His Highness Prince Aga Khan Shia Imami Ismaili } \\
\text { National Board/Portfolio for Canada }\end{array}$ \\
\hline
\end{tabular}




\begin{tabular}{|c|c|}
\hline Interview 16 & $\begin{array}{l}\text { Senior Member, His Highness Prince Aga Khan Shia Imami Ismaili } \\
\text { National Board/Portfolio for Canada }\end{array}$ \\
\hline Interview 17 & Program Officer, Aga Khan Foundation Canada \\
\hline Interview 18 & $\begin{array}{l}\text { Senior Executive, His Highness Prince Aga Khan Shia Imami Ismaili } \\
\text { National Council for Tanzania }\end{array}$ \\
\hline Interview 19 & $\begin{array}{l}\text { Senior Administrator, His Highness Prince Aga Khan Shia Imami } \\
\text { Ismaili National Social Welfare Board for Tanzania }\end{array}$ \\
\hline Interview 20 & $\begin{array}{l}\text { Senior Member, His Highness Prince Aga Khan Shia Imami Ismaili } \\
\text { National Youth and Sports Board for Tanzania }\end{array}$ \\
\hline Interview 21 & Senior Management Executive, Aga Khan Health Services, Tanzania \\
\hline Interview 22 & Senior Governance Executive, Aga Khan Health Services \\
\hline Interview 23 & Senior Executive, AKDN Resident Representative Office, Tanzania \\
\hline Interview 24 & Medical Education, Aga Khan University, East Africa \\
\hline Interview 25 & $\begin{array}{l}\text { Senior Management Executive, Aga Khan Education Services, } \\
\text { Tanzania }\end{array}$ \\
\hline Interview 26 & Senior Governance Executive, Aga Khan Education Services, Tanzania \\
\hline Interview 27 & $\begin{array}{l}\text { Interim Director, Aga Khan University Institute for Educational } \\
\text { Development, Eastern Africa }\end{array}$ \\
\hline Interview 28 & Executive Officer, Aga Khan Foundation, Tanzania \\
\hline Interview 29 & Senior Governance Executive, Aga Khan Foundation, East Africa \\
\hline Interview 30 & Senior Management Executive, Jubilee Insurance, Tanzania \\
\hline Interview 31 & CEO, First Microinsurance Agency, Tanzania \\
\hline Interview 32 & CEO and Country Manager, Diamond Trust Bank, Tanzania \\
\hline Interview 33 & $\begin{array}{l}\text { Management, Primary Medical Centres, Aga Khan Health Services, } \\
\text { Tanzania }\end{array}$ \\
\hline Interview 34 & $\begin{array}{l}\text { Acting Academic Head, Aga Khan University Advanced Nursing } \\
\text { School, Tanzania }\end{array}$ \\
\hline \multicolumn{2}{|c|}{$\begin{array}{l}\text { *His Highness Prince Aga Khan Shia Imami Ismaili National Board and Portfolios for Canada } \\
\text { include the following -Health Board, Education Board, Social Welfare Board, Economic Planning Board, } \\
\text { Youth and Sports Board, Grants and Review Board, Conciliation and Arbitration Board, Settlement } \\
\text { Portfolio, Women's Development and Poverty } \\
\quad * * 5 \text { additional interviews were conducted (one in Nairobi and four in Tanzania) and served as } \\
\text { general background information. }\end{array}$} \\
\hline
\end{tabular}




\section{REFERENCE LIST}

Adatia, A. K., \& King, N. Q. (1969). Some East African Firmans of H. H. Aga Khan III. Journal of Religion in Africa, 2(2), 179-191.

Aga Khan IV. (2012). A Life in the Service of Development. Politique International (English edition of special issue on Agence francais development), 134. Retrieved 20 October 2012, from http://akdn.org/2012april_politique_internationale.pdf

Aga Khan IV. (1986). The Constitution of the Shia Imami Ismaili Muslims. London: Islamic Publications.

Aga Khan III. (2005). The Memoirs of Sir Sultan Mohammed Shah (Vol. I and II): Pakistan Herald Publications (PVT.) Ltd. (Original work published 1954).

AKDN. (2007). Aga Khan Development Network: Economic Development, Social Development, Culture [Brochure]. Geneva, Switzerland.

AKDN. (2007a). Aga Khan Education Services - AKES Governance. Retrieved 30 August 2009, from http://www.akdn.org/akes_governance.asp

AKDN. (2007b). Aga Khan Health Services - AKHS Governance. Retrieved 30 August 2009, from http://www.akdn.org/akhs.asp\#governance

AKDN. (2007c). AKDN Orgnisational Chart. Retrieved 13 August 2009, from http://www.akdn.org/about_akdn_chart.asp

AKDN. (2007d, May). The Third Sector in Tanzania: Learning More About Civil Society Organizations, Their Capabilities and Challenges: An updating and dissemination of work started under the John Hopkins University Non-Profit organisation study. Retrieved 19 July 2009, from http://www.akdn.org/publications/civil_society_tanzania_third_sector.pdf

AKDN. (2007e, August). Social, Economic and Cultural Programmes of the Aga Khan Development Network: Tanzania [Brochure]. Geneva, Switzerland.

AKDN. (2007f). Speech by His Highness the Aga Khan at the Annual Meeting of The European Bank for Reconstruction and Development. Tashkent, Uzbekistan, May 5, 2003. Retrieved 29 November 2012, from http://www.akdn.org/Content/591 
AKDN. (2007g). Speech by His Highness the Aga Khan at the Opening of Alltex EPZ Limited. Athi River, Kenya, December 19, 2003. Retrieved 29 November 2012, from http://www.akdn.org/Content/596/Opening-of-Alltex-EPZ-Limited-at-AthiRiver

AKDN. (2007h). Address by His Highness the Aga Khan, Foundation Ceremony of the Delegation of the Ismaili Imamat. Ottawa, Canada, June 6, 2005. Retrieved 29 November 2012, from http://www.akdn.org/speeches/2005June6.html

AKDN. (2007i). Speech by His Highness the Aga Khan at the Graduation Ceremony of the Masters of Public Affairs (MPA), Programme at the Institut d'Etudes Politiques de Paris (Sciences Po). Paris, France, June 15, 2007. Retrieved 27 November 2012, from http://www.akdn.org/speeches_detail.asp?id=145

AKDN. (2007j). Speech by His Highness the Aga Khan at the Conference on Central Asia and Europe : A New Economic Partnership for the 21st Century. Berlin, Germany, November 13, 2007. Retrieved 29 November 2012, from http://www.akdn.org/Content/629

AKDN. (2007k). Address by His Highness the Aga Khan, Inaugural Ceremony of the Delegation of the Ismaili Imamat, Ottawa, Canada, December 6, 2008. Retrieved 29 November 2012, from http://www.akdn.org/Content/699

AKDN. (20071). Address by His Highness the Aga Khan to the Tutzing Evangelical Academy Upon Receiving the "Tolerance" Award. Tutzing, Germany. May 20, 200. Retrieved 29 November 2012, from http://www.akdn.org/Content/605

AKDN. (2007m). Address by His Highness the Aga Khan at the Leadership and Diversity Conference. Gatineau, Canada, May 19, 2004. Retrieved 30 June 2013, from http://www.akdn.org/Content/238

AKDN. (n.d). The Aga Khan Development Network in East Africa [Brochure]. Geneva, Switzerland.

AKES. (2003). Aga Khan Education Services [Brochure]. Geneva, Switzerland. Retrieved 1 August 2009, from http://www.akdn.org/publications/2004_akes_brochure.pdf

AKF. (2008). Aga Khan Foundation: An agency of the Aga Khan Development Network [Brochure]. Geneva, Switzerland. Retrieved 9 August 2009, from http://www.akdn.org/publications/2008_akf_brochure.pdf

Allegiance. (2012). In Merriam-Webster's Collegiate Dictionary. Retrieved 7 May 2012, from http://www.merriam-webster.com/dictionary/allegiance 
Asani, A. S. (2001). The Khojahs of South Asia: Defining a Space of their Own. Cultural Dynamics, 13(2), 155-168.

Aucoin, P. (1995). The new public management: Canada in comparative perspective. Montreal: Institute for Research on Public Policy.

Aziz, K. K. (Ed.). (1997). Aga Khan III selected speeches and writings of Sir Sultan Muhammad Shah (Vol. I \& II). London: Kegan Paul International.

Bannink, D., \& Hoogenboom, M. (2007). Hidden change: disaggregation of welfare state regimes for greater insight into welfare state change. Journal of European Social Policy, 17(1), 19-32.

Bocock, R. (1971). The Ismailis in Tanzania: A Weberian Analysis. The British Journal of Sociology, 22(4), 365-380.

Boyd, M. (2004). Dispute Resolution in Family Law: protecting choice, promoting inclusion. Retrieved 10 July 2010, from http://www.attorneygeneral.jus.gov.on.ca/english/about/pubs/boyd/.

Brandsen, T., \& Pestoff, V. (2006). Co-production, the third sector and the delivery of public services. Public Management Review, 8(4), 493-501.

Canada. Parliament. Senate. (2006, June 20). Proceedings of the Standing Senate Committee on Foreign Affairs, the development and security challenges facing Africa; the response of the international community to enhance that continent's development and political stability; and Canadian foreign policy as it relates to Africa, 39th Parliament, 1st Session. Issue 4 - Evidence. Retrieved 1 August 2009, from http://www.parl.gc.ca/Content/SEN/Committee/391/fore/04evae.htm?comm_id $=8 \&$ Language $=\mathrm{E} \& \mathrm{Parl}=39 \& \mathrm{Ses}=1$

Castells, M. (2004). Globalization, Identification and the State: A Powerless State or a Network State. In M. Castells The Power of Identity, The Information Age: Economy, Society and Culture (Vol. 2, pp. 303-366). Malden, Mass: Blackwell.

CIDA. (2012). Raising Canadian Public Awareness of Development. Retrieved 29 November 2012, from http://www.acdicida.gc.ca/cidaweb/cpo.nsf/vWebSEn?OpenView\&Restrict ToCategory $=099820$

Clark, G. (2007). Agents of Transformation? Donors, faith-based organisations and development. Third World Quarterly, 28(1), 77-96.

Clark, J. (1995). The state, popular participation, and the voluntary sector. World Development, 23(4), 593-601. 
Cohen, J., \& Arato, A. (1994). Civil society and political theory. Cambridge: MIT Press.

Daftary, F. (1990). The Ismailis their history and doctrines. Cambridge: Cambridge University Press.

Daftary, F. (1998). A short history of the Ismailis: traditions of a Muslim community. Edinburgh: Edinburgh University Press.

Daftary, F. (2001). The Ismailis: A Religious Community in Islam. Bulletin of the Royal Institute for Inter-Faith Studies, 3(1). Retrieved 12 October 2012, from http://www.riifs.org/journal/journal.htm

Daftary, F. (2011). Preface \& Introduction. In F. Daftary (Ed.), A Modern History of Ismailis: Continuity and Change in a Muslim Community (pp. xiii-xv; 1-15). New York: Palgrave.

Davis, P. R. (2001). Rethinking the Welfare Regime Approach. Global Social Policy, $1(1), 79-107$.

Deacon, B. (2003). The prospects for equitable access to social provision in a globalizing world. In A. Krizsan \& V. Zentai (Eds.), Reshaping Globalization multilateral dialogues and new policy initiatives (pp. 75-94 ). Budapest: CEU Press.

Dossa, P. A. (1985). Ritual and daily life : transmission and interpretation of the Ismaili tradition in Vancouver. (Doctoral dissertation). Retrieved from https://circle.ubc.ca/handle/2429/25559

Embuldeniya, D., Lasby, D., \& McKeown, L. (2002). An Analysis of Canadian Philanthropic Support for International Development and Relief. Toronto: Canadian Centre for Philanthropy. Retrieved 25 July 2009, from http://nonprofitscan.imaginecanada.ca/files/nonprofitscan/en/misc/canadi an_philanthropic_support.pdf

Esping-Andersen, G. (1990). The Three Worlds of Welfare Capitalism. Princeton: Princeton University Press.

Esping-Andersen, G. (1994). After the golden age: The future of the welfare state in the new global order. Geneva: United Nations Research Institute for Social Development.

Esping-Andersen, G. (1999). Social foundations of postindustrial economies. Oxford: Oxford University Press. 
Evans, P. (1997). Government action, social capital and development: reviewing the evidence on synergy. In P. Evans (Ed.), State-Society Synergy: Government and Social Capital Development. (pp. 178-209). University California at Berkeley: GAIA Research Series 94.

Evers, A. (1995). Part of the welfare mix: the third sector as an intermediate area. Voluntas, 6(2), 159-182.

Evers, A. (2005). Mixed Welfare Systems and Hybrid Organizations: Changes in the Governance and Provision of Social Services. International Journal of Public Administration, 28, 737-748.

Evers, A., Pijl, M., \& Ungerson, C. (Eds.). (1994). Payments for Care. Aldershot, UK: Avebury.

Finnemore, M. (1993). International Organizations as Teachers of Norms: The United Nations Educational, Scientific, and Cultural Organization and Science Policy. International Organization, 47(4), 565-597.

Florini, A. (2006). International NGOS. In R. A. W. Rhodes, S. A. Binder \& B. A. Rockman (Eds.), The Oxford handbook of political institutions (pp. 673-690). Oxford: Oxford University Press.

Flyvbjerg, B. (2006). Five Misunderstandings About Case-Study Research. Qualitative Inquiry, 12(2), 219-245.

Focus. (2009). FOCUS Humanitarian Assistance [Brochure]. Retrieved 1 August 2009, from http://www.akdn.org/publications/2009_focus_english.pdf

Fowler, A. (2000). NGO futures: beyond aid: NGDO values and the fourth position. Third World Quarterly, 21(4), 589-603.

Ghani, A., \& Lockhart, C. (2008). Fixing Failed States: A Framework for Rebuilding a Fractured World. Oxford: Oxford University Press.

Gillies, D. (Ed.). (1997). Strategies of public engagement : shaping a Canadian agenda for International co-operation. Montreal: McGill-Queen's University Press.

Gough, I. (2001). Globalization and Regional Welfare Regimes: The East Asian Case. Global Social Policy, 1(2), $163-189$.

Gough, I. (2004). Welfare regimes in development context: a global and regional analysis. In I. Gough, G. Wood, A. Barrientos, P. Bevan, P. Davis \& G. Room (Eds.), Insecurity and welfare regimes in Asia, Africa and Latin America (pp. 1548). Cambridge: Cambridge University Press. 
Graefe, P. (2004, July). Welfare regimes and the third sector: Rendering path dependency contingent?. Paper presented at the 6th International Conference of the International Society for Third-Sector Research, Contesting Citizenship and Civil Society in a Divided World, Toronto, Canada. Retrieved from http://www.istr.org/resource/resmgr/working_papers_toronto/graefe.peter.pdf

Haggard, S., \& Kaufman, R. (2008). Development, Democracy, and Welfare states : Latin America, East Asia, and Eastern Europe. Princeton N.J: Princeton University Press.

Hall, M. H., \& Reed, P. B. (1998). Shifting the burden: how much can government download to the non-profit sector. Canadian Public Administration, 41(1), 1-20.

Hall, P. A. (1993). Policy Paradigms, Social Learning, and the State: The Case of Economic Policymaking in Britain. Comparative Politics, 25(3), 275-296.

Harris, J. (2006). Development of Civil Society. In R. A. W. Rhodes, S. A. Binder \& B. A. Rockman (Eds.), The Oxford handbook of political institutions (pp. 131-143). Oxford: Oxford University Press.

Himbara, D. (1997). The 'Asian Question' in East Africa: The continuing controversy on the role of Indian capitalist in accumulation and development in Kenya, Uganda and Tanzania. African Studies, 56(1), 1-18.

Hirji, Z. (2011). The Socio-Legal Formation of the Nizari Ismailis of East Africa, 18001950. In F.Daftary (Ed.), A Modern History of Ismailis: Continuity and Change in a Muslim Community (pp. 129-159). New York: Palgrave.

Jansen, W. (1981). The Limits of Liberty in Canada: The Experience of the Mennonites, Hutterites, and Doukhobor. (Doctoral dissertation). Available from ProQuest Dissertation and Theses database.

Jennings, M. (2008). Surrogates of the state: NGOs, development, and ujamaa in Tanzania. Bloomfield, CT: Kumarian Press, Inc.

Jenson, J., \& Saint-Martin, D. (2003). New Routes to Social Cohesion? Citizenship and the Social Investment State. The Canadian Journal of Sociology, Special Issue on Social Cohesion in Canada, 28(1), 77-99.

Jessop, B. (1999). The Dynamics of Partnership and Governance Failure. In G. Stoker (Ed.), The New Politics of Local Governance in Britain (pp. 1-13). Oxford: Oxford University Press. Retrieved from http://eprints.lancs.ac.uk/210/ 
Kadende-Kaiser, R. M., \& Kaiser, P. J. (1998). Identity, Citizenship, and Transnationalism: Ismailis in Tanzania and Burundians in the Diaspora. Africa Today, 45(3/4), 461-480.

Kaiser, P. J. (1994). Culture and Civil Society in an International Context: The Case of Aga Khan Health Care and Education Initiatives in Tanzania. (Doctoral dissertation). Available from ProQuest Dissertations \& Theses database. (UMI No. 304115128)

Kaiser, P. J. (1995). State-society relations in an international context: the case of Aga Khan health-care initiatives in Tanzania. International Journal of Comparative Sociology, 36(3-4), 184-197.

Kaiser, P. J. (1996). Culture, Transnationalism and Civil Society: Aga Khan Social Services Initiatives in Tanzania. Westport, CT: Praeger Publishers.

Karim, K. H. (2011a). At the Interstices of Tradition, Modernity and Postmodernity: Ismaili Engagement with Contemporary Canadian Society. In F.Daftary (Ed.), $A$ Modern History of Ismailis: Continuity and Change in a Muslim Community (pp. 265-294). New York: Palgrave.

Karim, K. H. (2011b). Muslim Migration, Institutional Development, and the Geographic Imagination: The Aga Khan Development Network's Global Transnationalism. In J. DeBardeleben \& A. Hurrelmann (Eds.), Transnational Europe Promise, Paradox, Limits (pp. 205-221). England: Palgrave Macmillan.

Kassam, T. R. (2003). The Aga Khan Development Network: an ethic of sustainable development and social conscience. In R. C. Foltz, F. M. Denny \& A. Baharuddin (Eds.), Islam and ecology: a bestowed trust (pp. 477-496). Cambridge: Harvard University Press.

Keck, M. E., \& Sikkink, K. (1998). Activists Beyond Borders: Advocacy Networks in International Politics. Ithaca: Cornell University Press.

Keshavjee, R. (2004). The Redefined Role of the Ismaili Muslim Woman Through Higher Education and the Professions. (Doctoral dissertation). Available from ProQuest Dissertations \& Theses database. (UMI No. 305063880)

King, G., Keohane, R., \& Verba, S. (1994). Designing social inquiry scientific inference in qualitative research. Princeton, N.J: Princeton University Press.

Kolberg, J. E., \& Kolstad, A. (1992). Unemployment regimes. In J. E. Kolberg (Ed.), Between work and citizenship (pp. 171-192). New York: M. E. Sharpe, Inc. 
Laforest, R. (2011). Voluntary Sector Organizations and the State: Building New Relations. Vancouver: UBC Press.

Leurs, R., Tumaini-Mungu, P., \& Mvungi, A. (2011). Mapping the development activities of faith-based organizations in Tanzania. Working Paper. Birmingham, UK: University of Birmingham. Retrieved from http://www.religionsanddevelopment.org/files/resourcesmodule/@random454f80f 60b3f4/1300096184_working_paper_58_COMPLETE_FOR_WEB.pdf

Mahon, R. (2003, August). Yet Another “R”?" The Redesign and Rescaling of Welfare Regimes. Paper presented at the Workshop of the International Sociology Association's Research Group 19, Poverty, Social Welfare and Social Policy, Toronto, Canada.

Mahon, R. (2006). Of scalar hierarchies and welfare redesign: child care in three Canadian cities. Transactions of the Institute of British Geographers, 31(4), 452466.

March, J., \& Olsen, P. (2006). Elaborating the 'New Institutionalism'. In R. A. W. Rhodes, S. A. Binder \& B. A. Rockman (Eds.), The Oxford handbook of political institutions (pp. 3-20). Oxford: Oxford University Press.

Matthews, K. C. (2007). Ismailis in Canada: Locations of Subjectivity. (Doctoral dissertation). Available from ProQuest Dissertations \& Theses database. (UMI No. 304820692)

Mennonite Central Committee Canada. (n.d.). Purpose and Mission. Retrieved from $<$ http://mcccanada.ca/about/vision-mission>

Molina, A. H. (2009, November). Understanding Multi-sector Hybridity in Social Innovation: The University of Edinburgh and Fondazione Mondo Digitale. Retrieved from http://www.euclidnetwork.eu/files/paper_2.pdf

Morris, H. S. (1958). The Divine Kingship of the Aga Khan: A Study of Theocracy in East Africa. Southwestern Journal of Anthropology, 14(4), 454-472.

Mukadam, A., \& Mawani, S. (2006). Nizari Ismailis in the West: Negotiating National, Religious and Ethnic Identities. In L. Manney, Y. Kalogeras \& E. Arapoglou (Eds.), Transcultural Localisms: Responding to Ethnicity in a Globalized World (pp. 183-201). Heidelberg: Universitätsverlag Winter.

Najam, A. (2000). The Four-C's of third sector-government relations: cooperation, confrontation, complementarity, and co-optation. Nonprofit Management \& Leadership, 10(4), 375-396. 
Najam, A. (2006). Working with Government: Close but never too close. In G. Wood, A. Malik \& S. Sagheer (Eds.), Valleys in Transition: twenty years of AKRSP'S experience in Northern Pakistan (pp. 426-453). Oxford: Oxford University Press.

Nanji, A. (1974). Modernization and Change in the Nizari Ismaili Community in East Africa: A Perspective. Journal of Religion in Africa, 6(2), 123-139.

Nanji, A. (1983). The Nizari Ismaili Muslim Community in North America: Background and Development. In E. H. Waugh, B. Abu-Laban \& R. B. Quereshi (Eds.), The Muslim Community in North America (pp. 149-167). Edmonton: University of Alberta Press.

Ndegwa, S. N. (1996). The two faces of civil society :NGOs and politics in Africa. West Hartford, CT: Kumarian Press.

Osborne, S., \& McLaughlin, K. (2004). The Cross-Cutting Review of the Voluntary Sector: Where Next for Local Government- Voluntary Sector Relationships? Regional Studies, 38(5), 571-580.

Ostrom, E. (1997). Crossing the great divide: Coproduction, synergy, and development. In P. Evans (Ed.), State-Society Synergy: Government and Social Capital Development (pp. 85-118). University California at Berkeley: GAIA Research Series 94.

Pal, L. (2005). Case Study Method in Policy Analysis. In I. Geva-May (Ed.), Thinking Like a Policy Analyst: A Clinical Approach to Policy Analysis (pp. 227-258). New York: Palgrave Macmillan.

Palys, T. (1997). Research Decisions: Quantitative and Qualitative Perspectives (2nd ed.). Toronto: Harcourt Brace Jovanovich.

Patton, M. Q. (1999). Enhancing the quality and credibility of qualitative analysis. Health Services Research, 34 (5 Pt 2), 1189-1208.

Peck, J. (2002). Political Economies of Scale: Fast Policy, Interscalar Relations, and Neoliberal Workfare. Economic Geography, 78(3), 331-360.

Phillips, S. (2001). From Charity to Clarity: Reinventing Federal Government-Voluntary Sector Relationships. The Philanthropist, 16(4), 240-262.

Phillips, S., \& Levasseur, K. (2004). The snakes and ladders of accountability: Contradictions between contracting and collaboration for Canada's voluntary sector. Canadian Public Administration, 47(4), 451-474. 
Phillips, S., \& Orsini, M. (2002). Mapping the links: Citizen Involvement in Policy Processes Discussion Paper No. F|21. Ottawa: Canadian Policy Research Network.

Polanyi, K. (2001). The Great Transformation: The Political and Economic Origins of Our Time (2nd ed.). Boston: Beacon Press.

Raymond, S. (2004). The future of philanthropy: economics, ethics and management. Hoboken, N.J: John Wiley \& Sons.

Rudra, N. (2007). Welfare States in Developing Countries: Unique or Universal? Journal of Politics, 69(2), 378-396.

Ruthven, M. (2011). The Aga Khan Development Network and Institutions. In F.Daftary (Ed.), A Modern History of Ismailis: Continuity and Change in a Muslim Community (pp. 189-220). New York: Palgrave.

Sajoo, A. B. (2004). Muslim ethics : emerging vistas. London: I.B. Tauris Publishers in association with the Institute of Ismaili Studies.

Scholte, J. A. (2002). Civil society and governance in the global polity. In M. Ougaard \& R. Higgot (Eds.), Toward a Global Polity: Future Trends and Prospects (pp. 145165). London: Routledge.

Scholte, J. A. (2005). Globalization: A Critical Introduction (2nd ed.). New York: Palgrave Macmillan

Sellers, J. M., \& Lidström, A. (2007). Decentralization, Local Government, and the Welfare State. Governance, 20(4), 609-632.

Smillie, I., \& Hailey, J. (2001). Managing for change : leadership, strategy, and management in Asian NGOs. London: Earthscan Publications.

Steinberg, J. (2011). Isma 'ili Modern: Globalization and Identity in a Muslim Community. University of North Carolina Press.

Stone, D. (2001, April). Learning lessons, policy transfer and the international diffusion of policy ideas. CSGR Working Paper No. 69/01: Centre for the Study of Globalization and Regionalization. Retrieved 9 March 2012, Retrieved from http://www2.warwick.ac.uk/fac/soc/csgr/research/abstracts/abwp6901/

Stone, D. (2004). Transfer agents and global networks in the 'transnationalization' of policy. Journal of European Public Policy, 11(3), 545-566. 
Stubbs, P. (2003). International Non-State Actors and Social Development Policy. Global Social Policy, 3(3), 319-348.

Temu, A. E., \& Due, J. M. (2000). The business environment in Tanzania after socialism: challenges of reforming banks, parastatals, taxation and the civil service. The Journal of Modern African Studies, 34(4), 683-712.

Walji, S. R. (1974). A history of the Ismaili community in Tanzania. (Doctoral dissertation). Available from ProQuest Dissertations \& Theses database. (UMI No. 288086557)

Wood, G., \& Gough, I. (2004). Rethinking social policy in development contexts. In I. Gough, G. Wood, A. Barrientos, P. Bevan, P. Davis \& G. Room (Eds.), Insecurity and welfare regimes in Asia, Africa and Latin America (pp. 312-326). Cambridge: Cambridge University Press.

Wood, G., \& Gough, I. (2006). A Comparative Welfare Regime Approach to Global Social Policy. World Development, 34(10), 1696-1712.

Wood, G., \& Malik, A. (2006). Sustaining livelihoods and overcoming insecurity. In G. Wood, A. Malik \& S. Sagheer (Eds.), Valleys in Transition: twenty years of AKRSP's experience in Northern Pakistan (pp. 54-119). Oxford: Oxford University Press.

Yeates, N. (Ed.). (2008). Understanding Global Social Policy. Bristol: Policy Press. 


\section{APPENDIX}

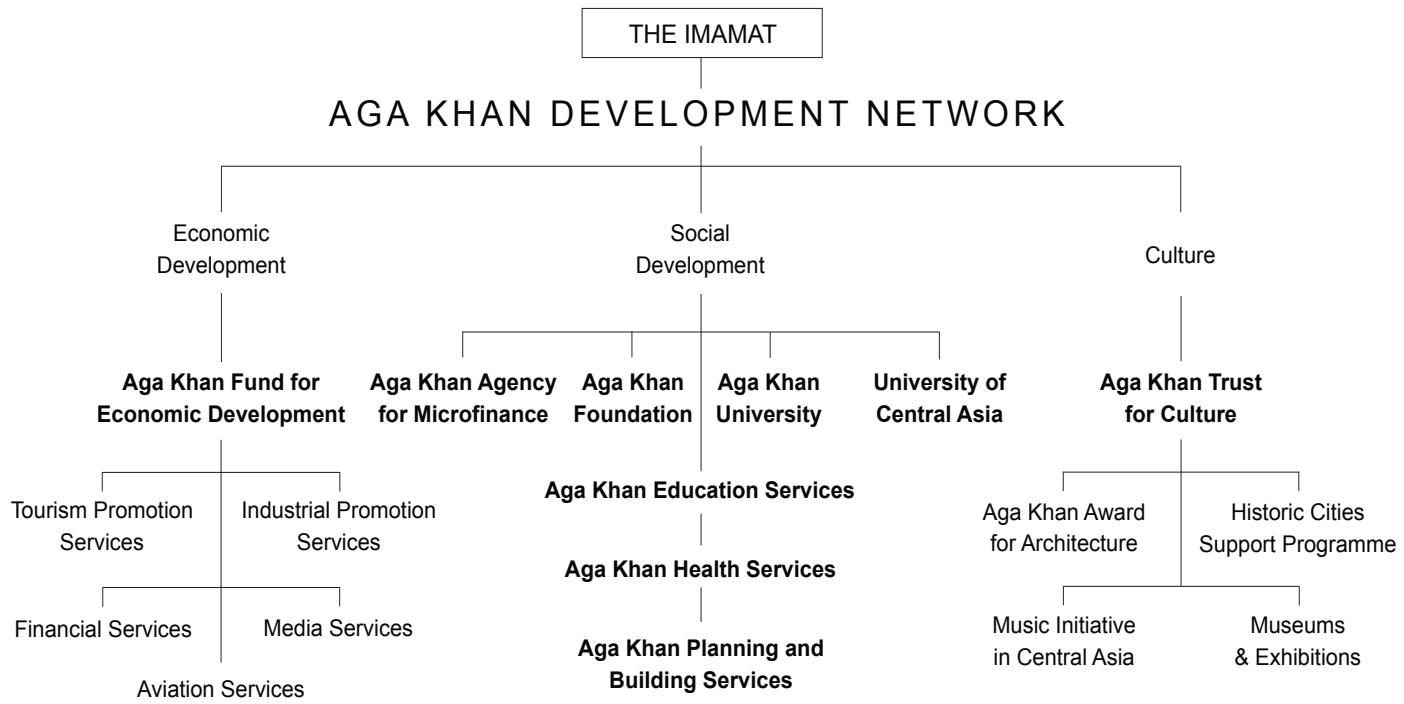

(AKDN, 2007c) 